\title{
Seismic Induced Architectural Damage to Masonry Structures at Mercury, Nevada
}

J. F. Wall, Jr.

RECEIVED

FEB 031997

OSTI

\section{MASTER}

June 1966

This is an informal report intended primarily for internal or limited external listribution. The opinions and conclusions stated are those of the author and may pr may not be those of the Laboratory.

Nork performed under the auspices of the U.S. Department of Energy by the awrence Livermore National Laboratory under Contract W-7405-ENG-48. 


\section{DISCLAIMER}

This report was prepared as an account of work sponsored by an agency of the United States Government. Neither the United States Government nor any agency thereof, nor any of their employees, make any warranty, express or implied, or assumes any legal liability or responsibility for the accuracy, completeness, or usefulness of any information, apparatus, product, or process disclosed, or represents that its use would not infringe privately owned rights. Reference herein to any specific commercial product, process, or service by trade name, trademark, manufacturer, or otherwise does not necessarily constitute or imply its endorsement, recommendation, or favoring by the United States Government or any agency thereof. The views and opinions of authors expressed herein do not necessarily state or reflect those of the United States Government or any agency thereof. 


\section{DISCLAMMER}

Portions of this document may be illegible in electronic image products. Images are produced from the best available original document. 
UNIVERSITY OF CALIFORNIA

Lawrence Radiation Laboratory

Livermore, California

SEISMIC INDUCED ARCHITECTURAL DAMAGE

TO MASONRY STRUCTURES AT MERCURY, NEVADA

(Title: Unclassified)

John F. Wall, Jr.

June 1966

\section{MASTER}
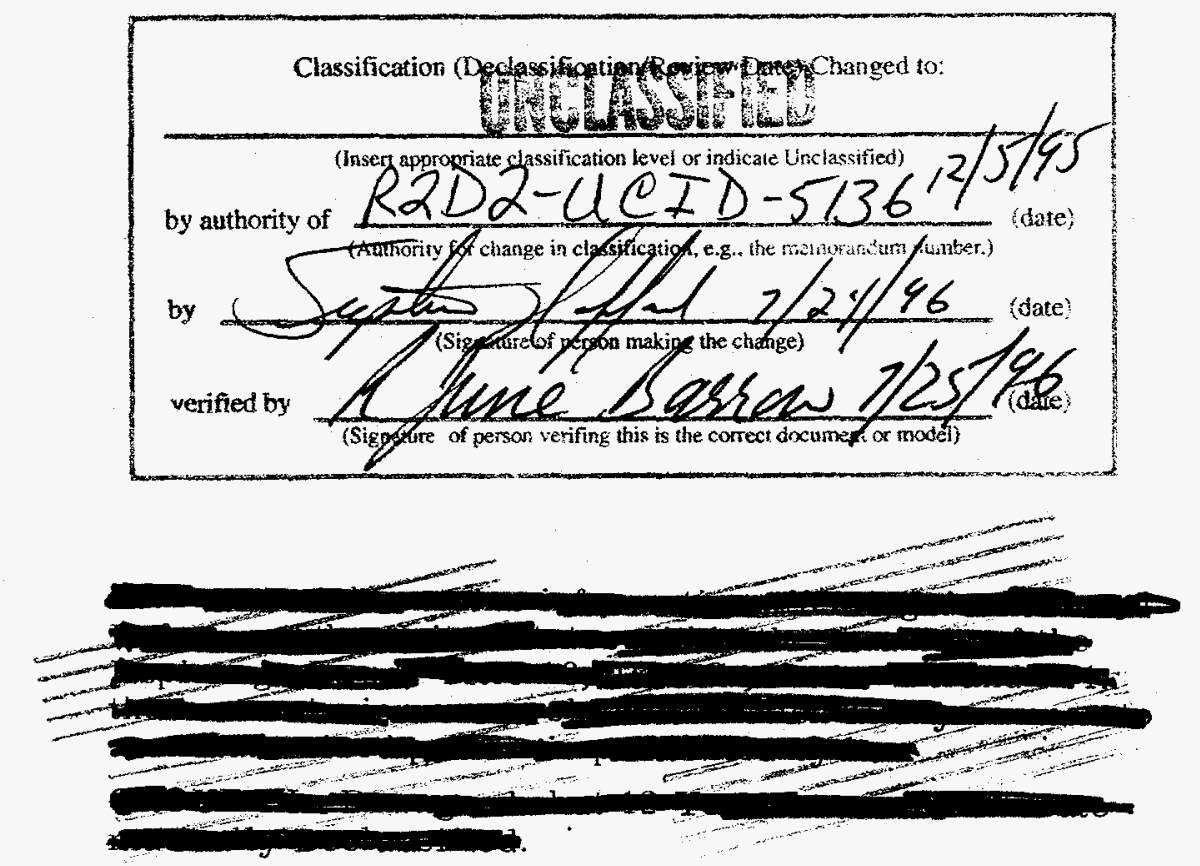

HH

DISTRIBUTION OF THIS DOCURENT IS UNUMITED 


\section{SEISMIC INDUCED ARCHITECTURAL DAMAGE \\ TO MASONRY STRUCTURES AT MERCURY, NEVADA \\ John F. Wall, Jr. \\ U. S. Army Corps of Engineers \\ University of California, Lawrence Radiation Laboratory \\ Livermore, California}

June 1966

ABSTRACT

Selected masonry structures in Mercury were inspected for cracking before and after certain nuclear detonations and during periods of no significant nuclear activity. Detonations gave peak particle velocities whose magnitudes approached those experienced in Mississippi during the Salmon event. Findings include evidence that peak particle velocities of 0.1 to $0.3 \mathrm{~cm} / \mathrm{sec}$ caused more cracking than normal; however, cracks at these low levels of motion are not more severe than those occurring naturally.

\section{INTRODUCTION}

There has been and continues to be much controversy as to the proper ground motion criteria for seismic damage to residential structures. Presently, there are at least five sets of criteria, each with some basis of credulity.

In independent analyses, L. Cauthen ${ }^{1,2}$ (see Fig. 1) and Duvall and Fogelson ${ }^{3}$ deemed peak particle velocity a better damage criterion than displacement and acceleration. However, it is probable that a true damage criterion should be based on analysis of the complete wave train. Until recently, 8 to $10 \mathrm{~cm} / \mathrm{sec}$ represented the threshold of

\footnotetext{
${ }^{1}$ L. J. Cauthen, Jr., "The Effects of Seismic Waves on Structures and Other Facilities," Third Plowshare Symposium, Engineering with Nuclear Explosives, University of California at Davis, Apr. 1964.

${ }^{2}$ L. J. Caithen, Jr., "Survey of Shock Damage to Surface Facilities and Drilled Holes Resulting from Underground Nuclear Detonations," Lawrence Radiation Laboratory, Livermore, Report UCRL-7964, 1964.

${ }^{3}$ W. I. Duvall and D. E. Fogelson, "Review of Criteria for Estimating Damage to Residences from Blasting Vibrations," Bureau of Mines Report of Investigation 5968, Apr. 1961 .
} 
minor damage (plaster cracking) to masonry residential-type structures. Duvall and Fogelson ${ }^{3}$ state that about $5 \mathrm{~cm} / \mathrm{sec}$ is a safe velocity for a high percentage (about $94 \%$ ) of cases. In heavily populated areas, however, 1 or 2 percent damage could well affect the feasibility of certain proposed Plowshare projects. For example, Hattiesburg citizens claimed damage to about 3 percent of their structures after the Salmon event, a 5-kt underground detonation 20 miles distant. Hattiesburg peak particle velocity was between 0.5 and $1 \mathrm{~cm} / \mathrm{sec}$. Figure 2 indicates claimed damage versus peak particle velocity, based on Salmon data compiled by D. Power. ${ }^{4}$ Complaints/number of families include damage complaints to timber and steel structures as well as masonry. If Fig. 2 were based on only masonry structures, higher damage would be expected and the curve would shift to the right. Claims are being settled at an average cost of $\$ 500$ each. ${ }^{4}$

\section{PURPOSE}

An investigation of selected representative buildings in Mercury, Nevada, close to many nuclear detonations within the Nevada Test Site, was designed to determine

1) the validity of peak particle velocity as a damage criterion,

2) the peak particle velocity which causes minor architectural damage to selected masonry structures,

3) the validity of the Hattiesburg experience, and

4) the natural cracking rate for masonry structures in Nevada.

\section{DISCUSSION}

\section{Implementation}

Building exteriors of 43 masonry structures at Mercury, Nevada, were inspected before and after detonations which gave peak particle velocities at Mercury whose magnitudes approached those experienced in the Hattiesburg area.

As far as practical, the time interval between preshot and postshot inspections of structures was held to a minimum to reduce the effect of the natural cracking phenomenon

\footnotetext{
${ }^{4}$ Dean V. Power, "A Survey of Complaints of Shock-related Damage to Surface Structures Resulting from the Salmon Event," Lawrence Radiation Laboratory, Livermore, Report UCRL-14110, Mar. 1965.
} 


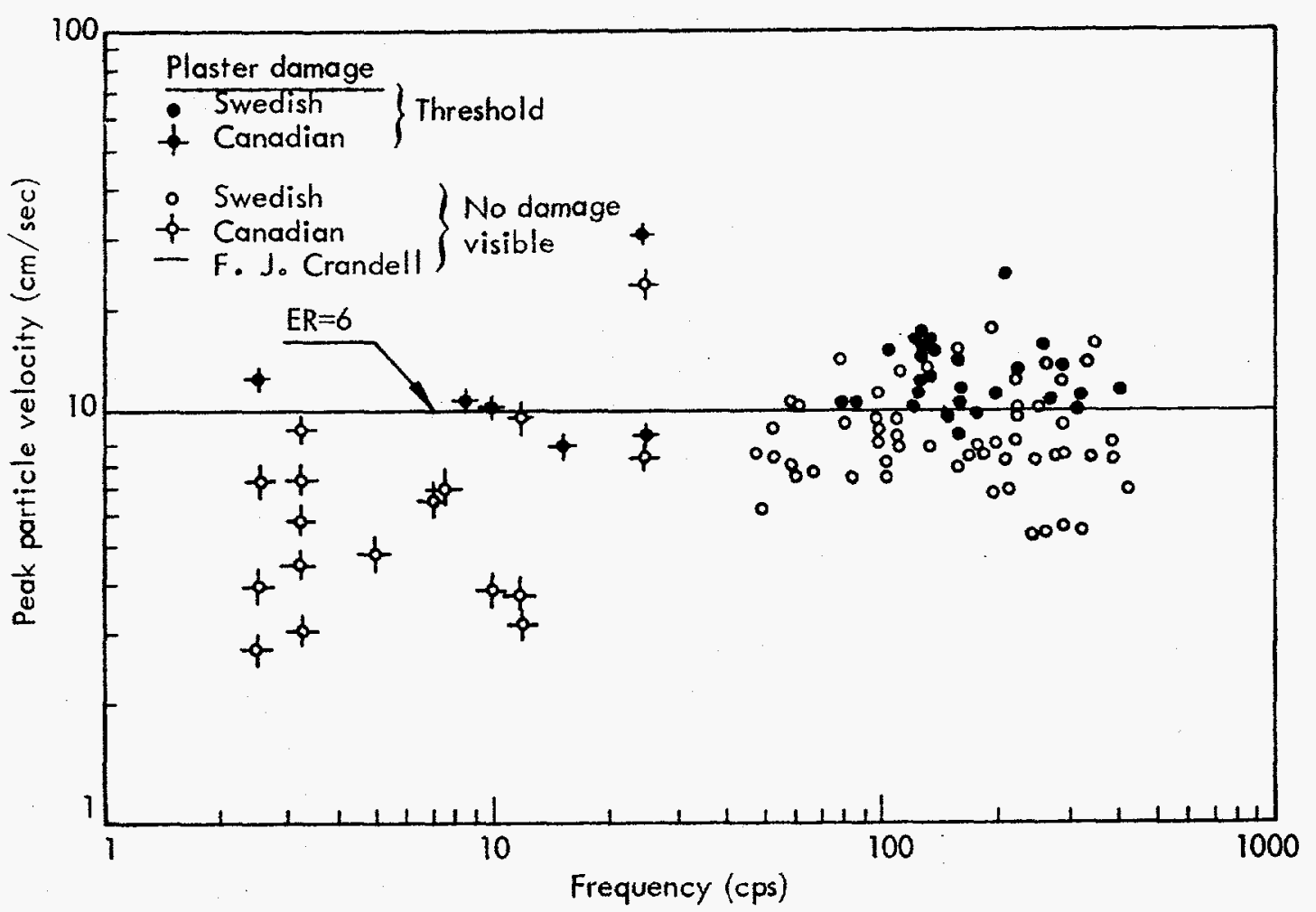

Fig. 1. Damage as a function of velocity showing independence of frequency (after L. Cauthen, UCRL-7964).2

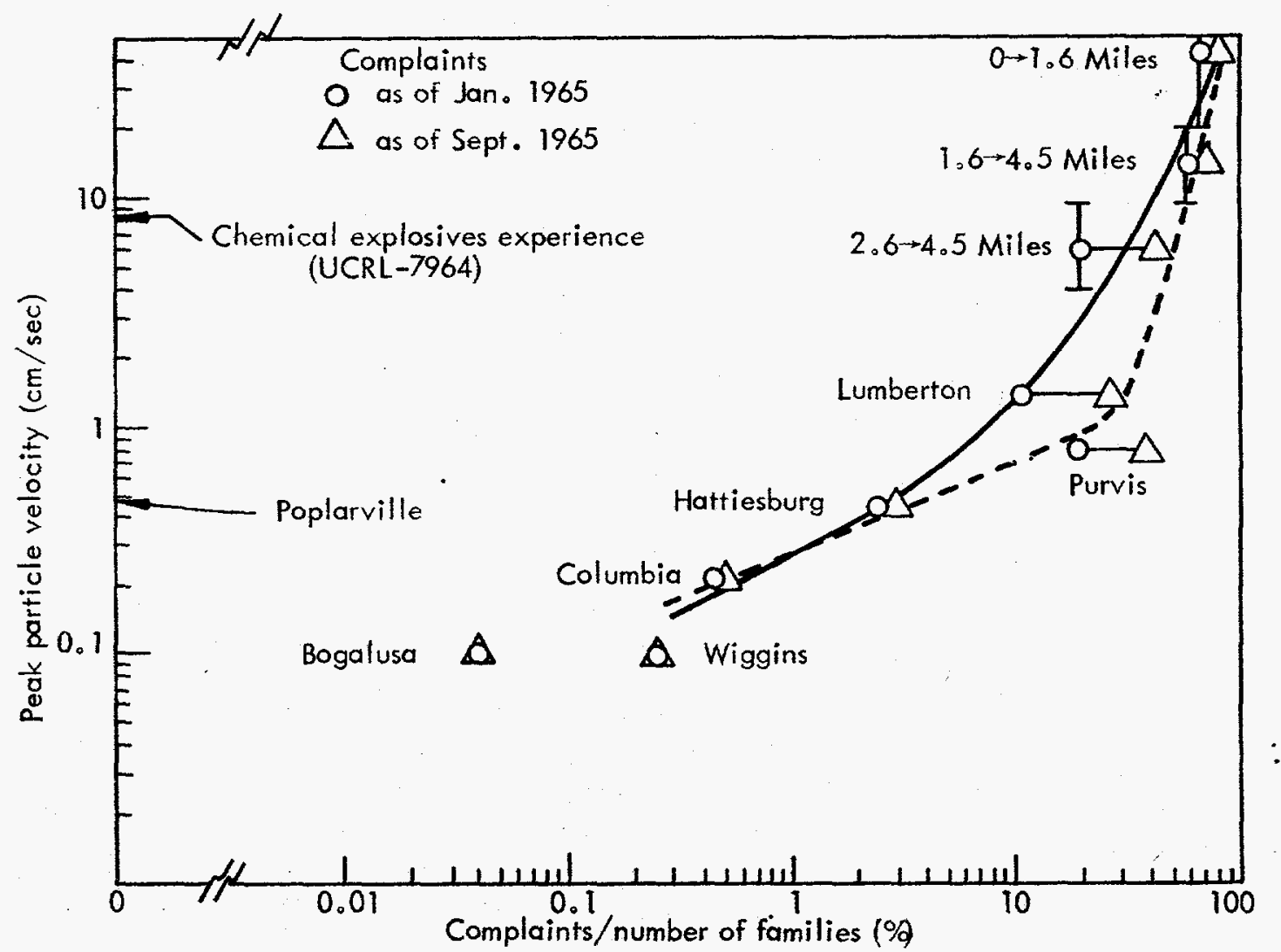

Fig. 2. Claimed architectural damage from Salmon as a function of peak particle velocity (after D. Power, UCRL-14110). ${ }^{4}$ 
which is large at Mercury. In order to determine this natural rate of cracking, inspections were made of these 43 buildings during periods when there were no significant nuclear tests.

The primary emphasis was at Mercury, but spot-check inspections were also conducted on structures at Beatty and Indian Springs Air Force Base in Nevada.

\section{Instrumentation}

Instrumentation for the first two events ( 3 Dec. 1965 and 16 Dec. 1965 ) is shown in Fig. 3. It consisted of the following:

1. Mercury
a. Six components, NGC-21, moving-coil geophones
b. Two components, Hall-Sears 10-1 geophones
c. Accelerograph
d. Sprengnether

2. Beatty
a. Wood-Anderson
b. Two accelerographs

3. Indian Springs
a. Accelerographs to the northwest
b. NGC-21 at Station SE-2, east of town

Subsequent events had the following coverage:

1. Mercury
a. Three components, NGC-21
b. Accelerograph

2. Beatty
a. Wood-Anderson
b. Accelerograph
c. Three components, NGC-21 (when available)

3. Indian Springs

"a. Accelerograph to the northwest

b. Three components, NGC-21, at Station $2 \mathrm{E}$

4. Tonopah

. a. Wood-Anderson

b. Three components, NGC-21 (when availäble) 


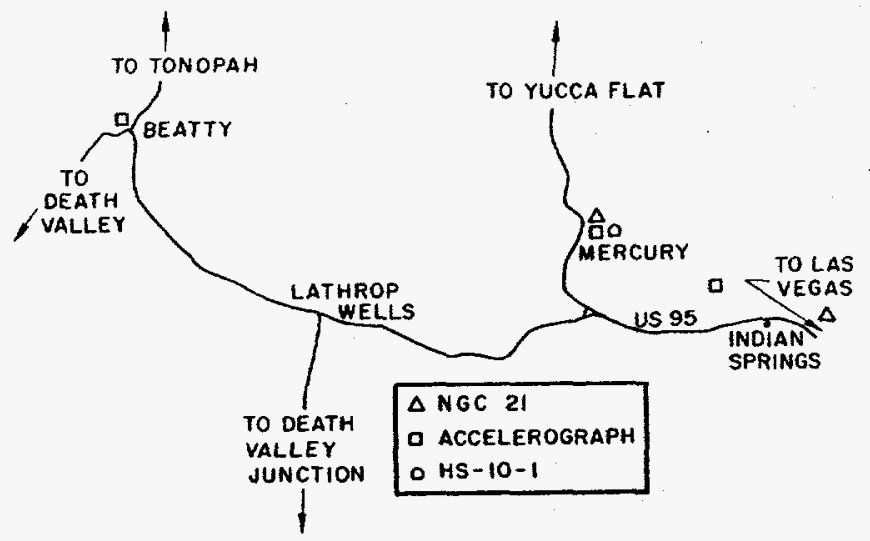

\section{AREA MAP}

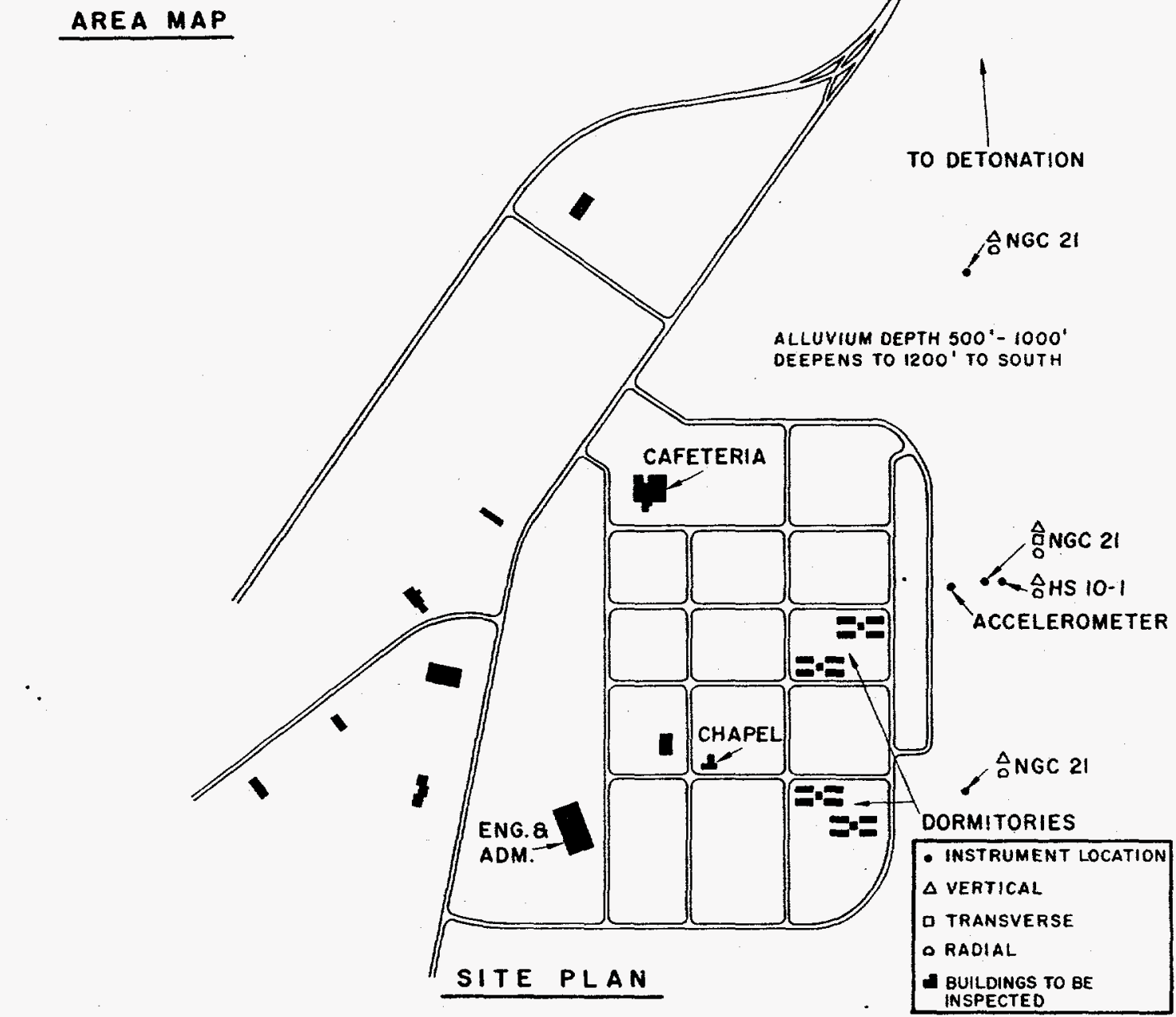

Fig. 3. Schematic of Mercury, Beatty, and Indian Springs and the available instrumentation for the 3 Dec. 1965 and 16 Dec. 1965 nuclear detonations. 
In addition, U. S. Coast and Geodetic Survey (USC\&GS) made available their NGC-21 instrumentation records from stations on a line southeast from Mercury towards Las Vegas and at various locations within Las Vegas.

\section{$\underline{\text { Relative Seismic Response }}$}

Frequently, ground motion amplitudes vary by factors of 2 to 3 , even within a small area. In order to establish the relative seismic response of the ground at various locations in Mercury, Dr. E. D. Alcock, USC\&GS, is continuing to record and analyze peak particle velocities with NGC-21 seismometers within the campsite during low-yield detonations. Vectorial addition of velocity components is incomplete.

Refer to Fig. 4 for building locations and approximate resultant peak particle velocities relative to Quonset 25. Relative seismicity is based on the master station at Quonset 25. Preliminary results indicate relatively higher motions at instruments located from east to west across the center of camp with lower motions at instruments in the north and south extremes. There appear to be high relative responses near Buildings 482, 477, 677, 525, and 550 .

\section{Proximity Gages}

Since there are extreme temperature changes in the desert near Mercury, existing building cracks might respond more to this type of stress than to Hattiesburg-type ground motion during events. In order to ascertain this movement, proximity gages were mounted across cracks in different locations during several events and during periods of no large nuclear activity. Results are found in Appendix C.

\section{Crack Definition}

What constitutes a crack? During the conduct of the experiment, a determined effort was made to include only those cracks similar to those for which claims were filed in the Hattiesburg area. In other words, only those new cracks or crack enlargements which would be objectionable to a fastidious building owner were considered. Shrinkage cracks were ignored. New, moderate (some flaking or spalling, easily distinguishable) cracks, spalling or flaking of old cracks, and obvious crack extensions were considered. as reasonable objectionable damage. Such categories were noted and marked. Only .. new cracks in the category moderate or severe were considered in the final tabulation of the data.

Masonry damage is gradual and not sharply defined. Probably several small existing cracks were judged insignificant and subsequently widened, extended, and/or spalled to an objectionable extent. These developed cracks were entered in inspectional 


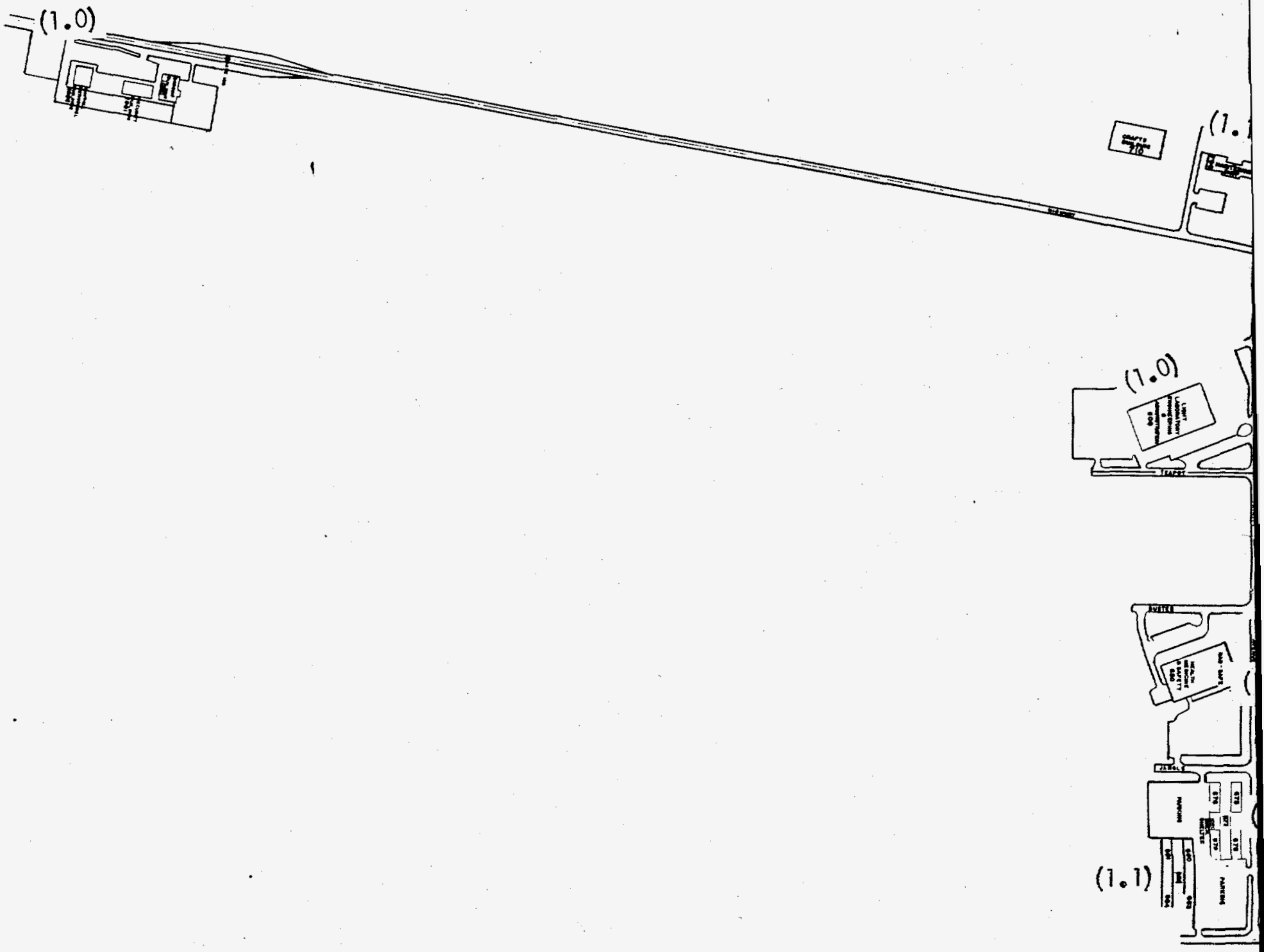

Fig. 4. Buildings and instrument loca velocities relative to Quonset 
$-7-$

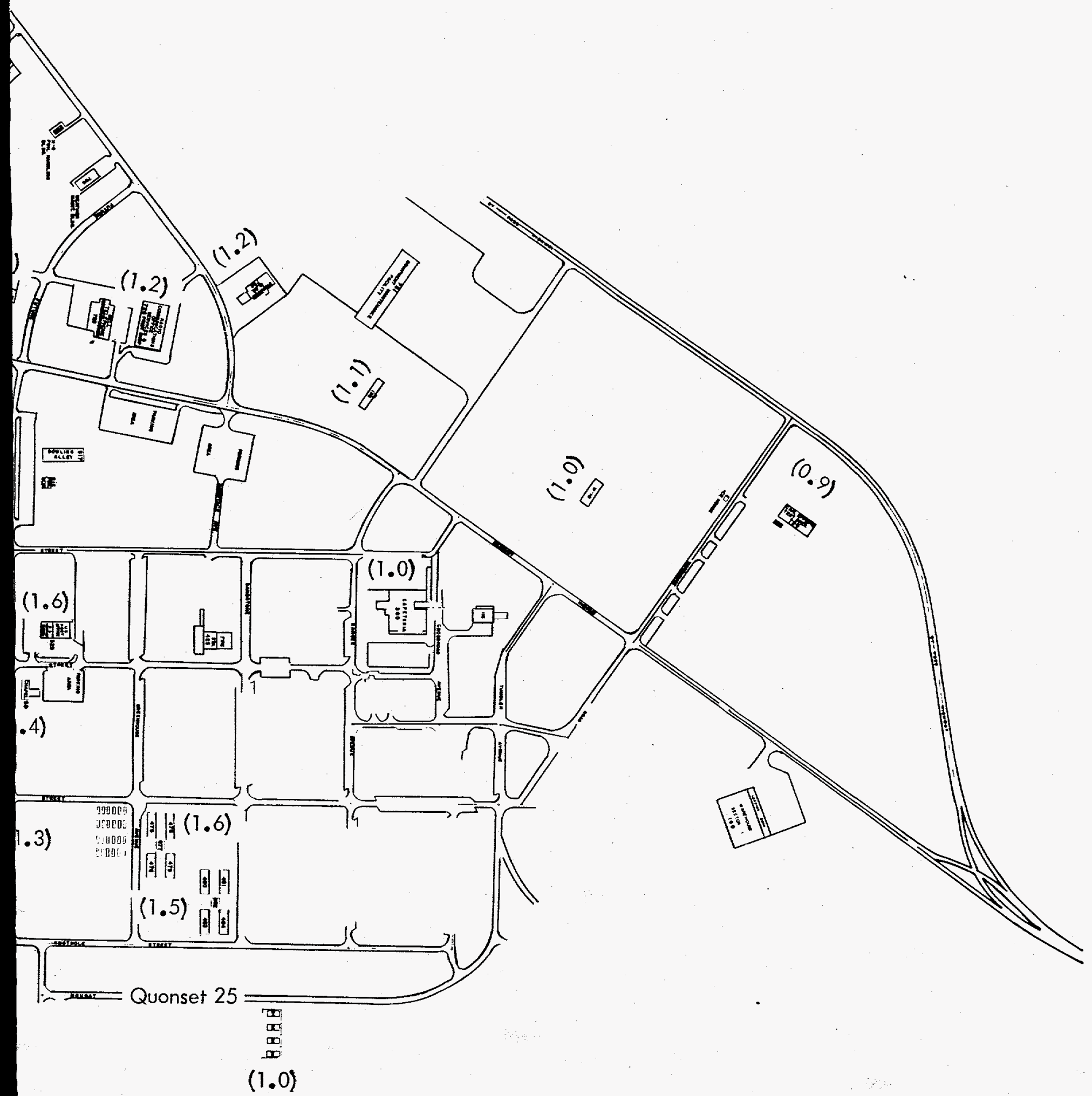

ions with approximate peak particle

25. 
data at the time of the "significant" determination, whether after a detonation or during a period of no induced seismic motion. There are wide differences in the conditions of different Mercury buildings, and each was judged on its own merit.

\section{Conduct of Inspection}

Due to the relatively large sample of 43 buildings and lack of experienced personnel, less than desirable techniques were employed initially. Inspections were not made during the same time of day, which allowed sun, shadow, and temperature to interfere with crack detection and evaluation. These deficiencies were corrected after the second inspection. On several occasions, the time interval between inspections was excessively long due to event delays and cancellations. Doubtful cracks discovered after an event were generally assumed to have been present during the pre-event inspection; likewise, doubtful cracks discovered during inspections unconnected with an event were assumed to have occurred during the time interval between inspections.

\section{RESULTS}

The first two inspections included 20 interiors as well as all exteriors of the 43 selected buildings. Due to limited personnel, subsequent inspections were conducted solely on exteriors. Data quoted reflect only exterior conditions. It is possible that more cracks were detected from a gain in experience after the first several inspections. As previously noted, doubtful cracks were assumed nonevent connected. The buildings were first examined on 1 Dec. 1965 for an event on 3 Dec. No weighted significance was given to length of cracks.

Table I summarizes inspection dates, new cracks detected, and, wher applicable, peak particle velocities. In some inspections, buildings were not examined in a single day; in all cases the time between consecutive inspections was weighed and averaged. Other categories of cracking (extensions and new flaking or spalling of existing cracks) are included in the data sheets of Appendix A. Table II lists maximum components of displacement or acceleration recorded on an accelerograph at Quonset 24.

In Appendix B, evidence is photographically. presented that there is relatively little difference in severity between cracks detected after detonations and those found during periods of no significant seismic activity. However, it is apparent from Fig. 5, in which the data of Table I are plotted, that cumulative cracks significantly increase after seismic motion comparable to that experienced from Salmon. Natural cracking rates, i. e., new 


\section{$-9-$}

Table I. Summary of inspection data for masonry buildings at Mercury.

\begin{tabular}{|c|c|c|c|c|c|c|}
\hline $\begin{array}{l}\text { Inspection } \\
\text { date } \\
\end{array}$ & $\begin{array}{c}\text { Number } \\
\text { of } \\
\text { buildings }\end{array}$ & $\begin{array}{c}\text { Number of } \\
\text { moderate } \\
\text { cracks }\end{array}$ & $\begin{array}{c}\text { Inspection } \\
\text { interval } \\
\text { (days) } \\
\end{array}$ & $\begin{array}{l}\text { Weighted } \\
\text { average } \\
\text { interval } \\
\end{array}$ & $\begin{array}{c}\text { Slope } \\
\text { (crack/day } \\
/ 43 \\
\text { buildings) } \\
\end{array}$ & $\begin{array}{c}\text { Approx resul- } \\
\text { tant peak par- } \\
\text { ticle velocity } \\
(\mathrm{cm} / \mathrm{sec})^{a} \\
\end{array}$ \\
\hline $\begin{array}{l}1 / 12 / 65+ \\
2 \text { days }\end{array}$ & 43 & \multicolumn{3}{|c|}{ Initial Inspection } & $2.5^{\mathrm{b}}$ & \\
\hline $\begin{array}{l}3 / 12 / 65 \\
3 / 12 / 65 \\
7 / 12 / 65\end{array}$ & $\begin{array}{l}10 \\
22 \\
11\end{array}$ & $\begin{array}{l}0 \\
4 \\
7\end{array}$ & $\begin{array}{c}2 \\
1-2 \\
7\end{array}$ & $2.8 \rightarrow 3$ & & $\begin{array}{l}0.18(3 / 12 / 65) \\
\text { Corduroy }\end{array}$ \\
\hline \multicolumn{5}{|c|}{ Detonation scheduling precluded preshot inspection } & $2.5^{b}$ & \\
\hline $\begin{array}{l}16 / 12 / 65 \\
16 / 12 / 65\end{array}$ & $\begin{array}{l}11 \\
32\end{array}$ & $\begin{array}{r}3 \\
55\end{array}$ & $\begin{array}{r}9 \\
13\end{array}$ & 12 & & $\begin{array}{l}0.21(16 / 12 / 65) \\
\text { Buff }\end{array}$ \\
\hline $\begin{array}{l}12 / 1 / 66 \\
13 / 1 / 66\end{array}$ & $\begin{array}{r}6 \\
37\end{array}$ & $\begin{array}{r}7 \\
68\end{array}$ & $\begin{array}{l}27 \\
28\end{array}$ & $27.8 \rightarrow 28$ & 2.68 & \\
\hline $\begin{array}{l}18 / 1 / 66 \\
18 / 1 / 66\end{array}$ & $\begin{array}{r}6 \\
37\end{array}$ & $\begin{array}{r}6 \\
24\end{array}$ & $\begin{array}{l}6 \\
5\end{array}$ & $5.1 \rightarrow 5$ & & $\begin{array}{l}0.13(18 / 1 / 66) \\
\text { Lampblack }\end{array}$ \\
\hline $15 / 2 / 66$ & 43 & 69 & 28 & 28 & 2.46 & \\
\hline $16 / 2 / 66$ & 43 & 2 & 1 & 1 & 2.0 & \\
\hline $22 / 3 / 66$ & 43 & 77 & 34 & 34 & 2.26 & \\
\hline $13 / 4 / 66$ & 43 & 49 & 22 & 22 & 2.23 & \\
\hline $14 / 4 / 66$ & 43 & 20 & 1 & 1 & $2.5^{\mathrm{b}}$ & $\begin{array}{l}0.18(14 / 4 / 66) \\
\text { Duryea }\end{array}$ \\
\hline $20 / 4 / 66$ & 43 & 28 & 6 & 6 & $2.5^{b}$ & $\begin{array}{l}\text { Possible sonic } \\
\text { boom crack- } \\
\text { ing }(19 / 4 / 66)\end{array}$ \\
\hline $26 / 4 / 66$ & 43 & 46 & 6 & & & $\begin{array}{l}0.32(25 / 4 / 66) \\
\text { Pinstripe }\end{array}$ \\
\hline $5 / 5 / 66$ & 43 & 19 & 9 & 9 & 2.1 & \\
\hline $6 / 5 / 66$ & 43 & 37 & 1 & 1 & & $\begin{array}{l}0.21(6 / 5 / 66) \\
\text { Chartreuse }\end{array}$ \\
\hline $12 / 5 / 66$ & 43 & 15 & 6 & 6 & 2.5 & \\
\hline $13 / 5 / 66$ & 43 & 28 & 1 & 1 & & $\begin{array}{l}0.17(13 / 5 / 66) \\
\text { Piranha }\end{array}$ \\
\hline $18 / 5 / 66$ & 42 & 11 & 5 & 5 & 2.2 & \\
\hline $19 / 5 / 66$ & 42 & 9 & 1 & 1 & & $\begin{array}{l}0.31(19 / 5 / 66) \\
\text { Dumont }\end{array}$ \\
\hline
\end{tabular}

\footnotetext{
${ }^{a}$ Where indicated, velocity was measured at Quonset 25 ; estimated accuracy $\pm 20 \%$.

${ }^{b}$ Postulated.
} 
$$
-10-
$$

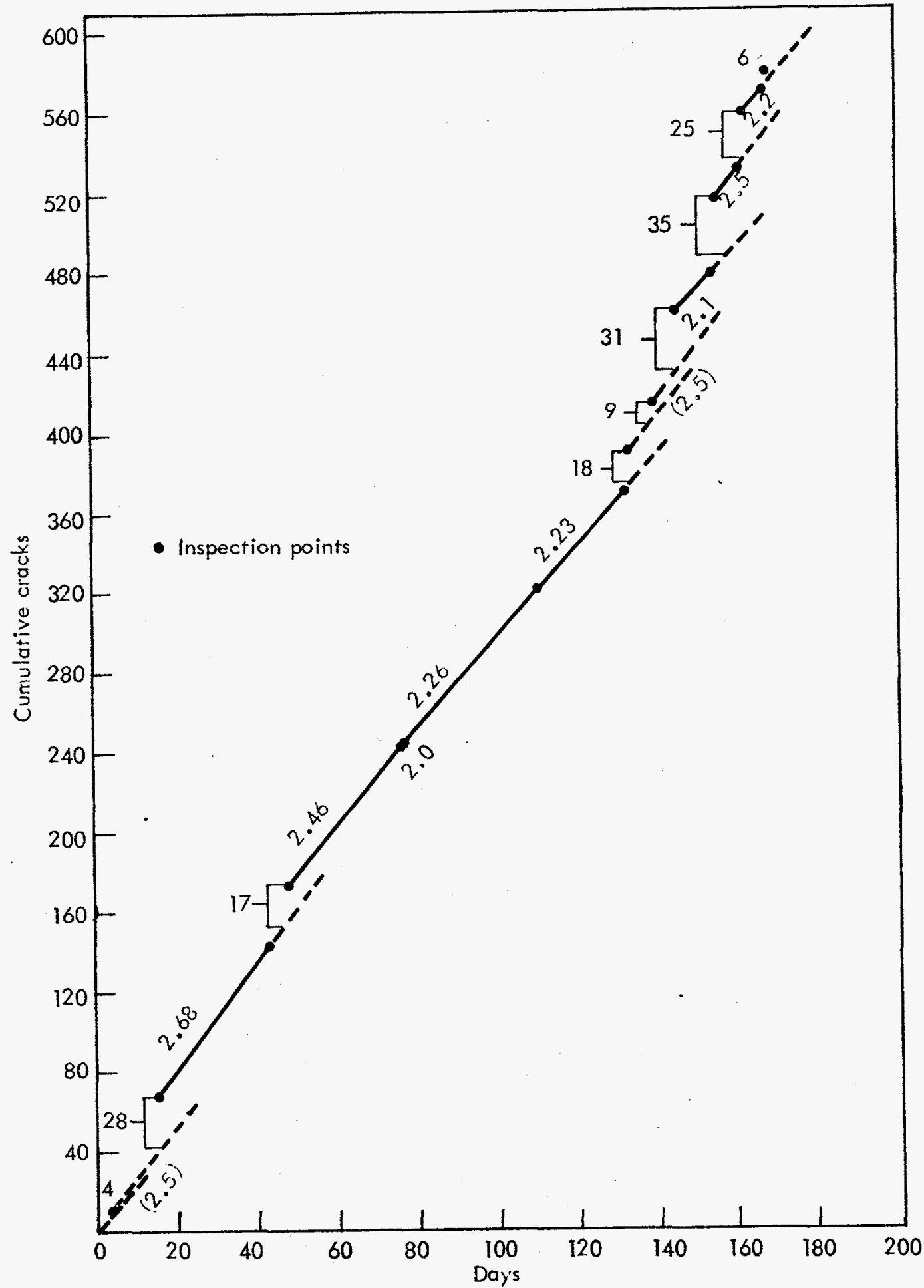

Fig. 5. Cumulative cracks and natural cracking rates for masonry buildings at Mercury. 
Table II. Summary of accelerograph data recorded at Quonset 24, Mercury.

\begin{tabular}{|c|c|c|c|c|c|c|}
\hline Date & Component & $\begin{array}{c}\text { Acceleration } \\
(\mathrm{g})\end{array}$ & $\begin{array}{c}\text { Period } \\
(\mathrm{sec})\end{array}$ & $\begin{array}{c}\text { Displacement } \\
(\mathrm{cm})\end{array}$ & $\begin{array}{c}\text { Period } \\
(\text { sec) }\end{array}$ & $\begin{array}{l}\text { Velocity } \\
(\mathrm{cm} / \mathrm{sec}) \\
\end{array}$ \\
\hline \multirow{3}{*}{$3 / 12 / 65$} & $\mathrm{Z}$ & 0.00256 & 0.3 & 0.02015 & 0.3 & 0.229 \\
\hline & $\mathrm{T}$ & 0.004 & 0.3 & 0.0883 & 2.0 & 0.589 \\
\hline & $\mathbf{R}$ & 0.0031 & 0.25 & 0.0682 & 2.3 & 0.456 \\
\hline \multirow[t]{3}{*}{$16 / 12 / 65$} & $z$ & 0.0041 & 0.4 & 0.0201 & 0.6 & 0.281 \\
\hline & $\mathrm{T}$ & 0.00171 & 0.3 & 0.053 & 2.3 & 0.299 \\
\hline & $\mathrm{R}$ & 0.00265 & 0.5 & 0.0398 & 1.6 & 0.322 \\
\hline \multirow[t]{3}{*}{$18 / 1 / 66$} & $\mathrm{Z}$ & 0.0012 & 0.2 & $\mathrm{~b}$ & & \\
\hline & $\mathrm{T}$ & 0.00114 & 0.12 & 0.0295 & 1.8 & 0.182 \\
\hline & $\mathrm{R}$ & 0.0014 & 0.4 & 0.0204 & 1.8 & 0.170 \\
\hline \multicolumn{2}{|l|}{$14 / 4 / 66$} & \multicolumn{2}{|c|}{ Accelerograph failure } & & & \\
\hline $25 / 4 / 66$ & & \multicolumn{2}{|l|}{ Not operated } & & & \\
\hline $6 / 5 / 66$ & & $\mathrm{~b}$ & & & & \\
\hline & $\mathrm{z}$ & 0.00214 & 0.32 & $\mathrm{~b}$ & & \\
\hline & $\mathrm{T}$ & 0.00236 & 0.4 & 0.204 & 3.4 & 0.69 \\
\hline & $\mathrm{R}$ & 0.00246 & 0.4 & 0.0624 & 2.4 & 0.389 \\
\hline \multirow[t]{3}{*}{$19 / 5 / 66$} & $\mathrm{Z}$ & $\mathrm{b}$ & & $\mathrm{b}$ & & \\
\hline & $\mathrm{T}$ & $\mathrm{b}$ & & 0.0265 & 2.36 & \\
\hline & $\mathrm{R}$ & 0.002 & $\mathrm{~b}$ & 0.034 & 1.6 & 0.245 \\
\hline
\end{tabular}

${ }^{a}$ Velocity computed from $v=\omega d$, where $\omega=\sqrt{\frac{a}{d}}$.

$\mathrm{b}_{\text {Unreadable at instrument maximum gain. }}$ 
cracks in 43 buildings divided by days since last inspection, are depicted as slopes. An average cracking rate of $2.5 \mathrm{cracks} /$ day/ 43 buildings appears reasonable.

After comparison with results of other detonations, the inspections subsequent to the detonations of 3 Dec. 1965 and 19 May 1966 indicated fewer new cracks than would be anticipated.

During an intermediate survey conducted $20 \mathrm{Apr}$. 1966, inspectors detected 9 cracks over the number normally associated with a commensurate time period. A possible source might have been a sonic boom which occurred 19 Apr. It startled several long-term Mercury residents, and was widely noted within the confines of the campsite. At the time of this reported shock wave, the barograph inside the Mercury weather building indicated an instantaneous rise of approximately $0.02 \mathrm{in}$. Wind gusts in excess of 35 knots were also reported during the interval since the preceding inspection, and the daily high temperatures dropped from 80 to $55^{\circ} \mathrm{F}$ between 17 and $18 \mathrm{Apr}$. However, comparable temperature and wind gust differentials were noted during other inspection intervals.

\section{CONCLUSIONS}

1. Variability of construction, age, traffic, use, temperature cycling, settling, and shrinkage cause damage to masonry. Such factors render difficult the accurate determination of a peak particle velocity damage index which is applicable to all cases.

2. During the period Dec. 1965 to May 1966, the Mercury normal cracking rate was approximately $2.5 \mathrm{cracks} /$ day $/ 43$ buildings. It is anticipated that cracking rates will vary seasonally.

3. Except for two large detonations in Yucca Valley where there may have been a relatively greater mismatch in the building and ground motion frequencies, the number of cumulative cracks increased appreciably with increases in peak particle velocities. If it is recognized that "it is the kinetic energy represented in the building vibration that is the measure of damaging potential and not necessarily the energy indicated in the ground motion," 5 peak particle velocity appears valid as a criterion for masonry damage to residential and single-story commercial type structures.

4. The Mercury inspection data indicated no flagrant inconsistencies with the Salmon experience in Mississippi. Peak particle velocities of 0.1 to $0.3 \mathrm{~cm} / \mathrm{sec}$ caused more cracks than normal. However, cracks at these low levels of motion are not more severe than those occurring naturally.

\footnotetext{
${ }^{5}$ F. Neumann, "Damaging Earthquake and Blast Vibrations," The Trend in Engineering, Jan. 1958.
} 
5. It is suggested that the Salmon damage complaints relative to peak particle velocity, Fig. 2, follows a log probability relationship (Fig. 6). If the ratio of number of families to number of structures is assumed to be one, the Salmon data indicates about $50 \%$ of the structures would suffer damage at peak particle velocities of 8 to 10 $\mathrm{cm} / \mathrm{sec}$. Since Fig. 2 places ro restriction on type of construction (steel, timber, masonry), higher damage would be expected on masonry structures and the curve would shift to the right. Such a postulated curve is also shown in Fig. 6 where percent masonry buildings in Mercury which were cracked over the normal rate are plotted and a parallel curve drawn.

These curves suggest two conclusions. If Salmon damage claims to all types of construction are valid, the $94 \%$ safe masonry cracking velocity of $5 \mathrm{~cm} / \mathrm{sec}$ is invalid. Secondly, the postulated Mercury curve indicates masonry cracking probabilities of over 0.95 for peak particle velocities of 8 to $10 \mathrm{~cm} / \mathrm{sec}$ which reaffirms the conclusions of Cauthen et al.

If the Salmon points of Hattiesburg, Purvis, and Lumberton were adjusted for approximate percentages of concrete block structures claimed to have been damaged, fairly good agreement with the postulated Mercury concrete block curve is shown in Fig. 7. However, it is recognized that little statistical validity can be attributed to only three points.

It is obvious that masonry damage thresholds should be expressed in terms of probability.

\section{RECOMMENDATIONS}

Experiments should be programmed to clarify seismic effects and to determine residential building amplification of ground motion.

Many factors determine the damaging potential of a nuclear detonation near metropolitan areas. Structural damage depends not only on yield and distance, but on coupling, soil amplification, building amplification, and travel path propagation and attenuation. Technical knowledge in the above areas is fairly advanced. Information on relative seismic response within small areas within a city is obtainable. There is little guidance, however, on what constitutes acceptable damage levels and the degree of liability which might be imposed by law.

Dominant periods of the average nuclear detonation are 0.2 to $4 \mathrm{sec}$ which correspond to the resonant frequencies of the majority of anycity's structures, i.e., homes, small com-

mercial buildings, and low public buildings. ${ }^{5}$ F. Neumann writes, ". . the cause of excessive damage on deep alluvial soils may be due as much to the existence of resonant ground and

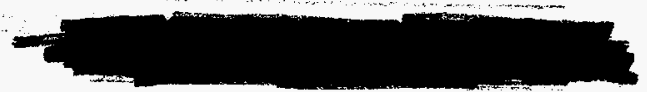




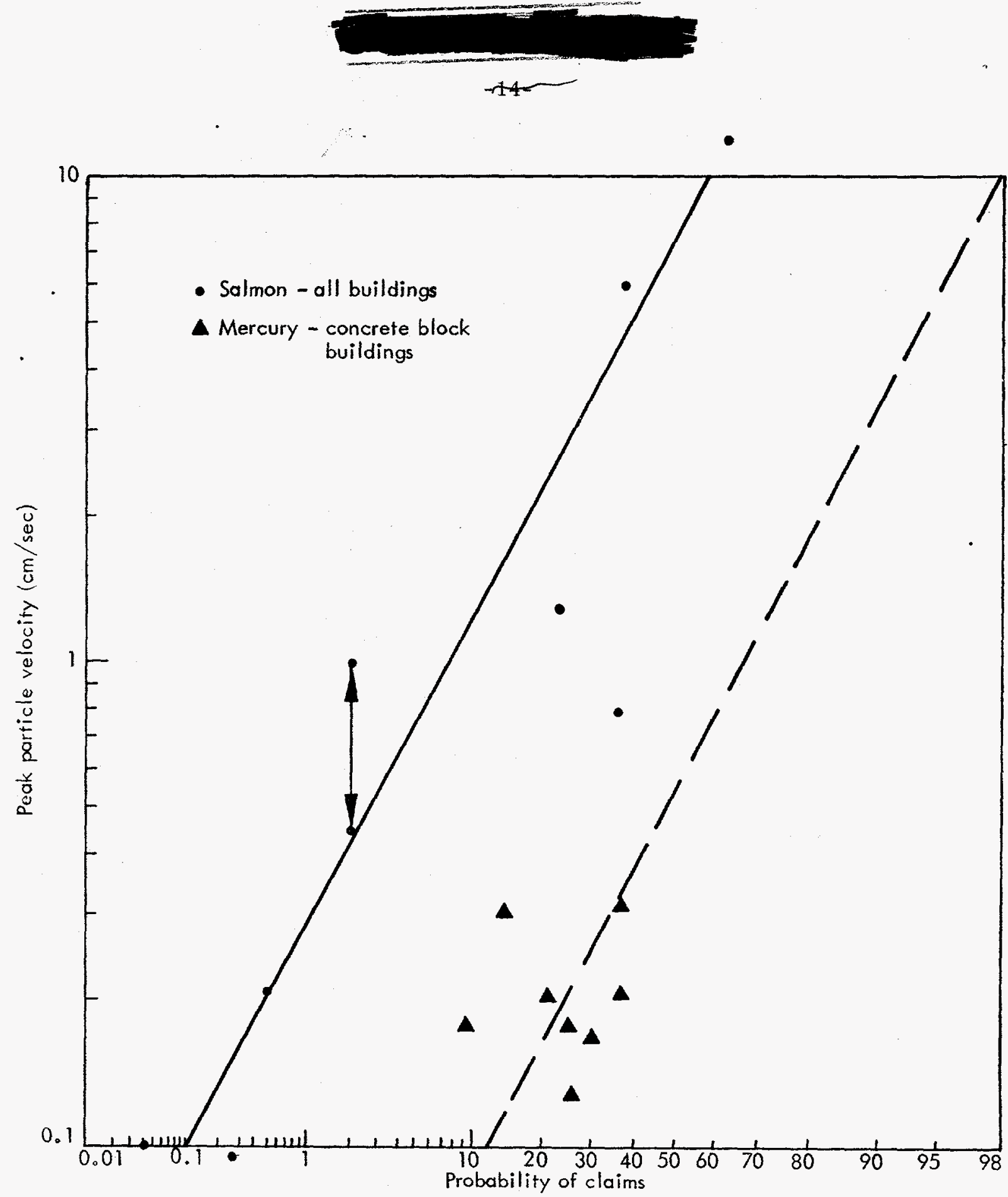

Fig. 6. Probability of claims as a function of peak particle velocity. 


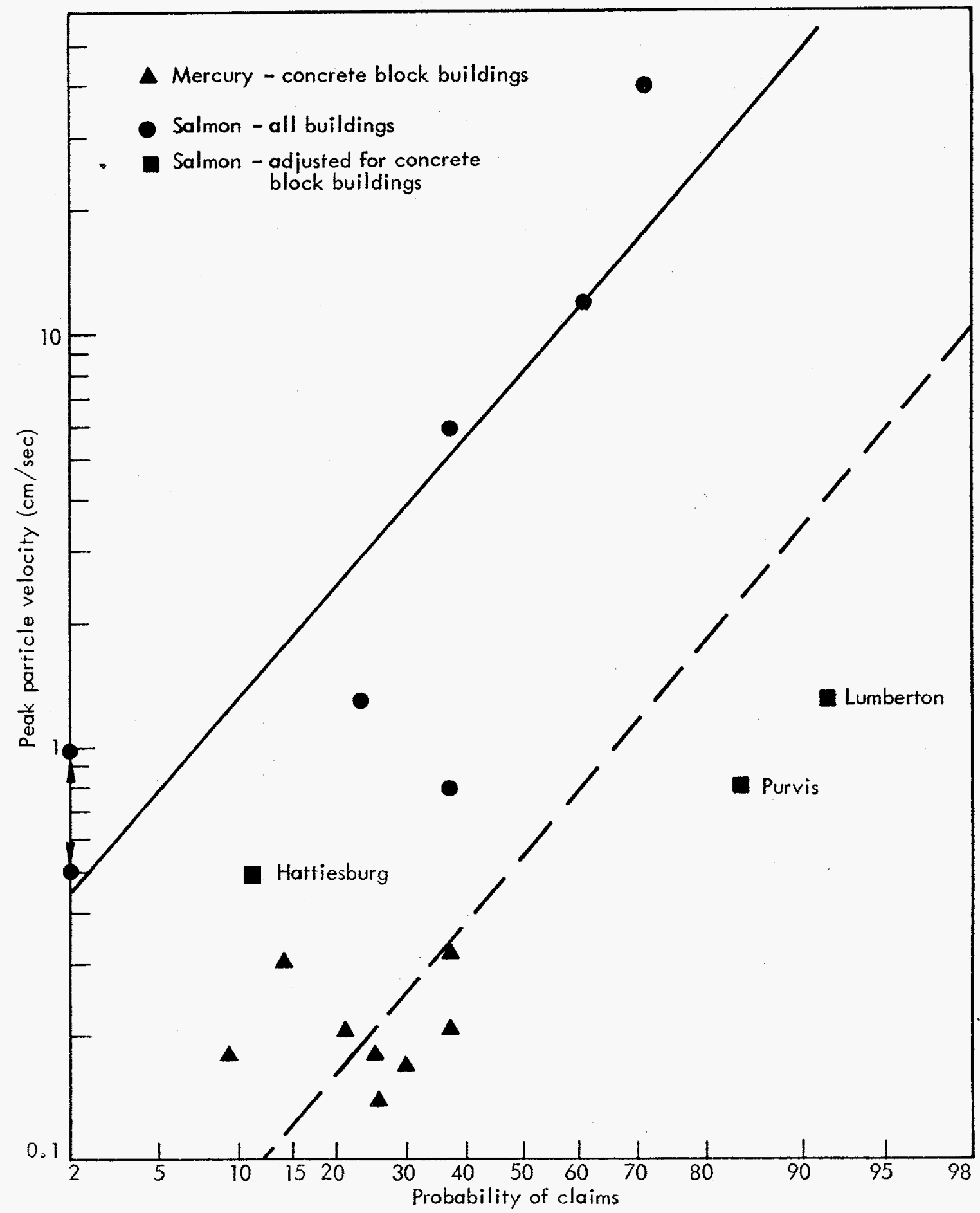

Fig. 7. Probability of claims as a function of peak particle velocities with three Salmon locations adjusted for approximate percentages of concrete block structures claimed to be damaged. 
building periods as to the greater ground amplitudes generally found on such formations." 5 He proposes a factor of 4 as representative of this amplification at resonance for low: buildings and from 4 to 10 for tall structures. At resonance, damping limits the damage as shown in the classical amplification expression, ${ }^{6}$

$$
A=1 \sqrt{\sqrt{\left(1-\frac{T_{0}^{2}}{T^{2}}\right)^{2}+\left(\alpha \frac{T_{0}}{T}\right)^{2}}},
$$

where $\mathrm{T}=$ ground oscillation period, $\mathrm{T}_{0}=$ natural period of the structures, and $\alpha=$ damping coefficient of the natural oscillation of the structure.

Sadoviskii ${ }^{6}$ indicates that $\alpha$ is rarely over 0.2 , which yields a maximum resonant amplification of 5 . The above considerations underline the significance of building amplification. Unless building amplitude modification is understood, ground motion criteria for masonry damage has little meaning.

In anticipating seismic damage from future nuclear detonations, the following areas might present a more optimistic view.

Longer periods are associated with higher yields and lower coupling media. Detonations of this type would tend to give a mismatch between periods of low structures and those of the ground, especially at greater distances. Figure 8 indicates fewer cracks at Mercury from two large-yield events in Yucca Valley than smaller detonations giving the same relative peak particle velocities in Mercury. More experience with relatively large yields in Yucca Valley might generate a line with the same slope as that drawn in Fig. 8 but with crack values down by a factor of 5 .

Mercury experience indicates that at a particular location, cracks occur naturally in concrete block structures at a standard rate. Also from Mercury, there is evidence that ground peak particle velocities in the range from 0.1 to $0.3 \mathrm{~cm} / \mathrm{sec}$ cause some prompt cracking; however, it appears that this cracking would have occurred naturally in a matter of time.

Superficial damage in structures is first noted in grades V-VI as defined by the Modified Mercalli Scale which corresponds to tentative peak particle velocities of 2.25$4.5 \mathrm{~cm} / \mathrm{sec}^{5,7}$ If we assume that the building and ground act in resonance with a maximum amplification of 5 , ground velocities may be as low as $0.45-0.9 \mathrm{~cm} / \mathrm{sec}$ to cause these intensities within the structure. Therefore, a technically legitimate approach to claim adjustments for justifiable damage to low and residential masonry structures from ground

6

F. A. Kirillov, "The Problem of Investigation of the Seismic Effect of Explosions at the Institute of Physics of the Earth, USSR Academy of Sciences," Problems of

Engineering Seismology, cdited by S. V. Medvedev, Translation from the Russian, Consultants Bureau, New York, 1963.

${ }^{7}$ F. Neumann, "Seismological Aspects of the Earthquake Engineering Problem," Third Northwest Conference of Structural Engineers, Washington State University, Pullman, Washington, Mar. 1959.

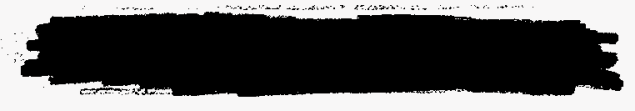




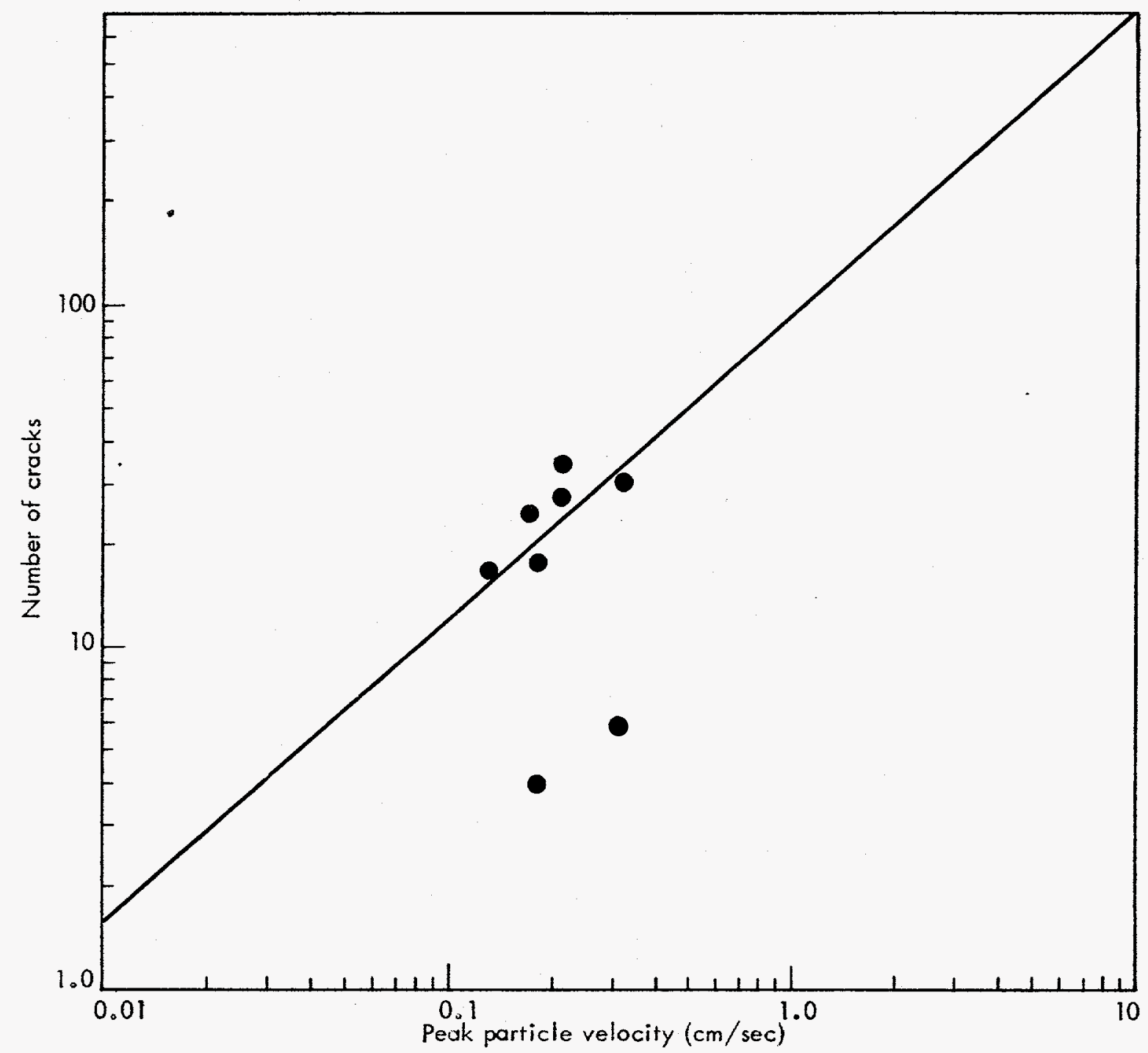

Fig. 8. Peak particle velocities and number of associated cracks over the normal cracking rate for Mercury concrete block structures. 
velocities lower than $0.45-0.9 \mathrm{~cm} / \mathrm{sec}$ would be to evaluate the estimated prompt cracking damage in terms of the normal structural cracking rate, and allowing payment of equivalent temporal depreciation of the value of the structure. For example, a peak particle velocity of $0.3 \mathrm{~cm} / \mathrm{sec}$ generates 33 cracks over the normal Mercury crack rate of 2.5 cracks/day (Fig. 8) which corresponds to 13 days of cracking precipitated in a single day.

\section{ACKNOWLEDGMENTS}

Grateful acknowledgment is extended to the following persons: Mr. D. D. Rabb, for not only collecting much of the information, but also assisting immeasurably in assembling and presenting the data; Messrs. S. E. Warner and J. T. Lane, who fielded and operated proximity gages, strain gages, and moving coil geophones during long periods of time without relief; Mr. W. J. Herlihy and Major P. Bazilwich, Jr. for their kind assistance in collecting data; Dr. E. D. Alcock and Mr. K. King and his associates from the United States Coast and Geodetic Survey, who made their velocity instrumentation records available; Dr. D. N. Montan, who gave valuable suggestions on data interpretation, and Messrs. F. R. Perry and C. H. Drury for their inspections on Building 425. 
APPENDIX A

INSPECTION DATA SHEETS

INSPECTION DATE: 3,7 December 1965

PREVIOUS INSPECTION: 1-2 December 1965

INTERVAL: 1, 2, 7 days (see below for interval-days between inspections) TOTALS: Cracks, 11; Flaking, 2; Extensions, 16

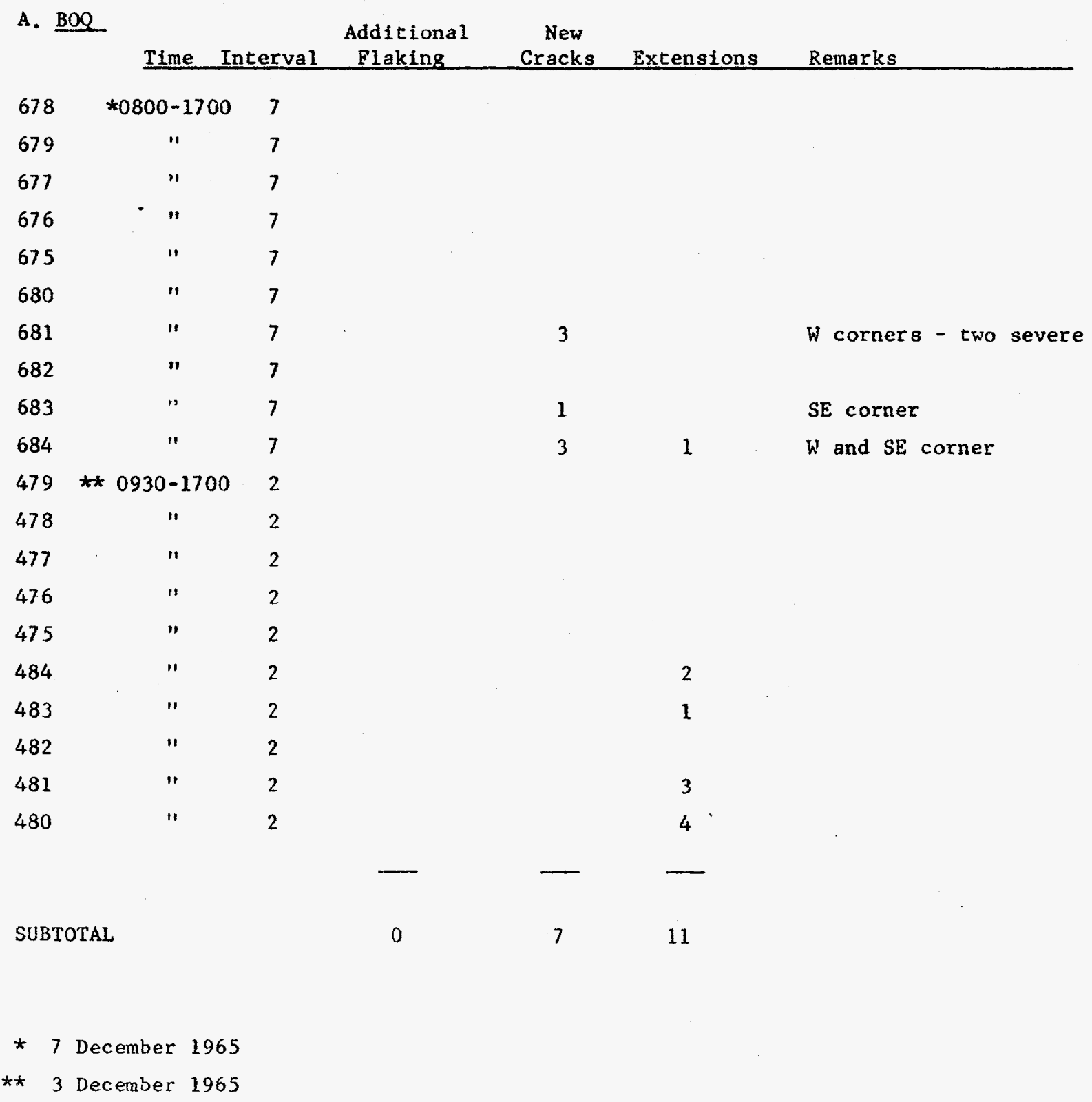


INSPECTION DATE: 3, 7 December 1965

\section{B. Other Bldgs,}

\begin{tabular}{|c|c|c|c|c|c|c|c|}
\hline & & Time & Interval & $\begin{array}{l}\text { Additional } \\
\text { Flaking }\end{array}$ & $\begin{array}{c}\text { New } \\
\text { Cracks }\end{array}$ & Extenstons & Remarks \\
\hline 1002 & ** & * $0930-1700$ & 1 & & & & \\
\hline 1001 & & $"$ & 1 & & & & \\
\hline 1000 & & $"$ & 1 & & 1 & & above $\mathrm{E}$ door \\
\hline 710 & & $"$ & 1 & & & & \\
\hline 700 & & $"$ & 1 & & & & \\
\hline 725 & & $"$ & 1 & & & & \\
\hline 726 & & $"$ & 1 & & & & \\
\hline 703 & & $"$ & 1 & & & & \\
\hline 702 & & $" 1$ & 1 & & & & \\
\hline 701 & & $"$ & 1 & & & 1 & \\
\hline 752 & & $"$ & 1 & & 1 & 1 & above $\mathrm{N}$ door \\
\hline 751 & & $"$ & 1 & & 1 & & left of $N$ small door \\
\hline 155 & & $"$ & 1 & & & 1 & \\
\hline 790 & & $" 1$ & 1 & & & & \\
\hline 160 & & $"$ & 1 & & & & \\
\hline 300 & & $"$ & 1 & 2 & 1 & & \\
\hline 425 & & $"$ & 1 & & & & \\
\hline 525 & & $" 1$ & 1 & & & & \\
\hline 550 & & $" 1$ & 1 & & & 1 & \\
\hline 650 & & $"$ & 1 & & & 1 & \\
\hline 600 & * & $0800-1700$ & 7 & & & & \\
\hline 516 & $* \star$ & $0930-1700$ & 1 & & & & \\
\hline 517 & & $"$ & 1 & & & & \\
\hline SUBTC & oraL & & & 2 & 4 & 5 & \\
\hline
\end{tabular}

\footnotetext{
* 7 December 1965

** 3 December 1965
} 
INSPECTION DATE: 16 December $1965\left(39^{\circ}-32^{\circ} \mathrm{F}\right.$, wind 11 knots)

PREVIOUS INSPECTION: 3,7 December 1965

INTERVAL: 9,13 days (* denotes 9-day interval)

TOTALS: Cracks, 58; Flaking, 5; Extensions, 6 .

\section{A. $\mathrm{BOQ}$}

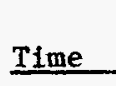

$678 *$

$0800-1700$

$679 *$

$677 *$

$676 *$

$675 *$

$680 *$

$681 *$

$682 *$

683*

$684 *$

479

478

477

476

475

484

483

482

481

480

SUBTOTAL

14

"1

11$$
\text { "1 }
$$$$
\text { "1 }
$$

$"$

11$$
"
$$

if

"

11

\section{Additional} Plaking

1

1

1

$$
1130-1700 \quad 1
$$

3

1

6

5

1

2
New Cracks Extensions

Remarks
SE corner
NE corner

NW corner

$E \& W$ ends, $S$ side

$N E$ corner \& $W$ end, $N$ side

Under air conditioner, $E$ end, $N$ side

Under air conditioner, $E$ and $W$ ends, $S$ side

Under air conditioner, $E$ end $S$ side

Under air cond., $E \& W$ ends $\mathrm{N} \& \mathrm{~S}$ sices; NW corner

NE corner, under air cond. $W \& E$ ends, $S$ side 
INSPECTION DATE: 16 December 1965

B. Other B1dgs.

\section{Time}

Additional Flaking

$1130-1700$

1002

1001

1000

710

700

725

726

703

702

701

752

751

155

790

160

300

425

525

550

650

$600 *$

516

517

SUBTOTAL
")

"

"1

19

1

"

11

"1

17

11

$"$

It

11

1

11

11

11

n

11

1

$\because$

11

"

2
New Cracks

Extensions

1

2

7

2

4

1

1

2

4

1

1

1

1

mostly S side

door, south side

$E$ and $W$ sides

E side

N side

1

E side

E wall only

E side

E side
SE corner, above $N$ door

above $\mathbf{S}$ door, SW corner 
INSPECTION DATE: 12,13 January $1966\left(56^{\circ}-38^{\circ} \mathrm{F}, 6\right.$ knots $)$

PREVIOUS INSPECTION: 16 December 1965

INTERVAL: 27,28 days (* denotes 27 day interval)

TOTALS: Cracks, 75 - Flaking, 15 - Extensions, 5

\begin{tabular}{|c|c|c|c|c|c|}
\hline A. BOO & Time & $\begin{array}{c}\text { Additional } \\
\text { Flaking } \\
\end{array}$ & $\begin{array}{c}\text { New } \\
\text { Cracks }\end{array}$ & Extensions & Remarks \\
\hline 678 & 1320 & & 1 & & \\
\hline 679 & 1340 & & 1 & & Many car nícks $E$. end \\
\hline 677 & 1355 & & & & \\
\hline 676 & 1400 & 1 & 1 & & \\
\hline 675 & 1415 & 1 & 1 & 1 & \\
\hline 680 & 1427 & & & & . \\
\hline 681 & 1510 & & 1 & & E. end S, side \\
\hline 682 & 1505 & & 1 & & E. side \\
\hline 683 & 1456 & & 1 & & E. side \\
\hline 684 & 1445 & & 2 & & W. end \& S.E. corner \\
\hline 479 & 0956 & & 1 & 1 & E. end S, side \\
\hline $478^{*}$ & 1645 & & 1 & & E. end S. side \\
\hline 477 & 1218 & & & & \\
\hline 476 & 1255 & & & & \\
\hline 475 & 1230 & & 2 & & W. side \\
\hline $484^{*}$ & 1550 & & & & \\
\hline $483^{*}$ & 1450 & & & & \\
\hline $482^{*}$ & 1510 & & & & \\
\hline $481^{*}$ & 1320 & 1 & 3 & & S. end E. side \\
\hline $480^{\star}$ & 1405 & $\ldots$ & $\begin{array}{l}3 \\
--\end{array}$ & $\cdots$ & sides of SE corner \\
\hline SUBTOTAL & & 3 & 19 & 2 & \\
\hline
\end{tabular}


INSPECTION DATE: 12, 13 January 1966

B. Other buildings

\begin{tabular}{|c|c|c|c|c|c|}
\hline & Time & $\begin{array}{c}\text { Additional } \\
\text { Flaking } \\
\end{array}$ & $\begin{array}{c}\text { New } \\
\text { Cracks }\end{array}$ & Extensions & Remarks \\
\hline 1002 & 1100 & & 1 & & NE corner \\
\hline 1001 & 1530 & 1 & 2 & & NE corner $\& S$ side \\
\hline 1000 & 1550 & & 1 & & E side \\
\hline 710 & 1415 & & 4 & & \\
\hline 700 & 1430 & 2 & 5 & & \\
\hline 725 & 1515 & 1 & 1 & & \\
\hline 726 & 1530 & & 1 & & \\
\hline 703 & 1550 & & 2 & & $N \& S$ sides \\
\hline 702 & 1610 & & 1 & & W side \\
\hline 701 & 1615 & & 2 & & \\
\hline 752 & 1635 & 1 & 3 & & \\
\hline 751 & 1010 & & 3 & & \\
\hline 155 & 1030 & & & 1 & \\
\hline 790 & 1440 & 2 & 5 & & $E \& N$ sides \\
\hline 160 & 1635 & & 2 & & \\
\hline 300 & 1050 & & 3 & & \\
\hline 425 & 1230 & & & & $\begin{array}{l}\text { Cracks at construction } \\
\text { joints }\end{array}$ \\
\hline 525 & 1330 & & & & \\
\hline 550 & 1345 & 1 & 5 & 1 & E. side \\
\hline 650 & 1405 & & 3 & & E side \\
\hline 600 & 1305 & 4 & 10 & & mostly $S \& W$ sides \\
\hline 516 & 1320 & & - 1 & & E side \\
\hline 517 & 1300 & - & 1 & 1 & N side \\
\hline \multicolumn{2}{|c|}{ SUBTOTAL } & 12 & 56 & 3 & \\
\hline
\end{tabular}




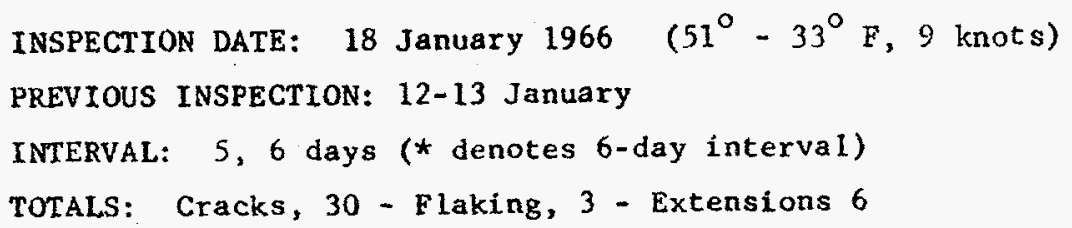

\section{Time} Additional Flaking

$678 \quad 1442$

679

1446

$677 \quad 1440$

$676 \quad 1437$

$675 \quad 1429$

$680 \quad 1452$

$681 \quad 1500$

$682 \quad 1510$

$683 \quad 1522$

$684 \quad 1512$

$479 \quad 1300$

$478^{*} \quad 1600$

$477 \quad 1545$

$476 \quad 1530$

$475 \quad 1540$

$484^{*} \quad 1405$

$483^{*} \quad 1415$

$482^{*} \quad 1400$

$481^{*} \quad 1335$

$480^{*} \quad 1350$

SUBTOTAL

\begin{abstract}
1350
\end{abstract}

New
Cracks
Extensions

\section{1}

1

2

2

1

1

2

11
NE corner Remarks

NW corner

NE corner

$E$ end $S$ side

NE corner

$E$ end $S$ side

$E$ end $\mathrm{N}$ side 
INSPECTION DATE: 18 January 1966

B. OTHER BLDGS.

\begin{tabular}{|c|c|c|c|c|c|}
\hline & Time & $\begin{array}{c}\text { Additional } \\
\text { Flaking }\end{array}$ & $\begin{array}{c}\text { New } \\
\text { Cracks }\end{array}$ & Extensions & Remarks \\
\hline 1002 & 1430 & & 1 & & E wall \\
\hline 1001 & 1420 & & 3 & & SW corner \& W wall \\
\hline 1000 & 1410 & & & & \\
\hline 710 & 1445 & & 2 & 1 & $S$ side \\
\hline 700 & 1500 & 1 & 4 & 1 & \\
\hline 725 & 1650 & & 4 & & \\
\hline 726 & 1645 & & & & \\
\hline 703 & 1550 & & & & \\
\hline 702 & 1520 & & & & \\
\hline 701 & 1525 & 1 & 2 & 1 & $\mathrm{NE}$ corner \\
\hline 752 & 1550 & & 1 & & above door W side \\
\hline 751 & 1600 & & & 1 & \\
\hline 155 & 1610 & & & 2 & \\
\hline 790 & 1440 & & 1 & & Fire hydrant $W$ side \\
\hline 160 & 1635 & & & & \\
\hline 300 & 1145 & & & & \\
\hline 425 & 1700 & & & & \\
\hline 525 & 1205 & 1 & & & \\
\hline 550 & 1225 & & & & \\
\hline 650 & 1230 & & & & \\
\hline 600 & 1305 & & & & \\
\hline 516 & 1345 & & & & \\
\hline 517 & 1355 & - & 1 & - & Front screen wall. \\
\hline \multicolumn{2}{|c|}{ SUBTOTAL } & 3 & 19 & 6 & \\
\hline
\end{tabular}


INSPECTION DATE: 15 February $1966\left(45^{\circ}-31^{\circ} \mathrm{F}, 30\right.$ knots $)$

PREVIOUS INSPECTION: 18 January 1966

$\left(14^{\circ} \mathrm{F}\right.$ differential in reported daily

INTERVAL: 28 days

highs, $12^{\circ} \mathrm{F}$ in daily lows, gusts of 30 knots)

TOTALS: Cracks, 69; Flaking, 32; Extensions, 11

\begin{tabular}{|c|c|c|c|c|c|}
\hline A. $\quad \underline{B O Q}$ & Time & $\begin{array}{c}\text { Additional } \\
\text { Flaking } \\
\end{array}$ & $\begin{array}{r}\text { New } \\
\text { Cracks } \\
\end{array}$ & Extensions & Remarks \\
\hline 678 & 1000 & 4 & 1 & & W. end \\
\hline 679 & 1021 & 2 & 2 & & $\mathrm{E}$ end $\mathrm{S}$ side \\
\hline 677 & 1045 & & & & \\
\hline 676 & 1050 & 3 & 2 & & $E$ end $N \& S$ side \\
\hline 675 & 1122 & 2 & 3 & 1 & NW corner \& $E$ end; $S$ side \\
\hline 680 & 1344 & & & & \\
\hline 681 & 1310 & & 1 & & $W$ end \\
\hline 682 & 1305 & & & . & \\
\hline 683 & 1230 & & & & \\
\hline 684 & 1250 & 1 & 1 & & $W$ end $S$ side \\
\hline 479 & 0845 & & & & $\begin{array}{l}479 \& 478 \text { predicted } \\
\text { "hot spots" }\end{array}$ \\
\hline 478 & 0950 & & 2 & & $W$ end $\& E$ end $N$ side \\
\hline 477 & 1040 & & & & \\
\hline 476 & 1616 & 2 & & & \\
\hline 475 & 1645 & 1 & & 1 & \\
\hline 484 & 1415 & & & & \\
\hline 483 & 1435 & 1 & 1 & & $W$ end $N$ side \\
\hline 482 & 1510 & & & & \\
\hline 481 & 1542 & 1 & 3 & & $W$ end-Hard to detect \\
\hline 480 & 1515 & $\begin{array}{r}1 \\
\end{array}$ & 2 & - & $\begin{array}{l}\text { Under air conditioner; } \\
W . \text { end } N \text {, side }\end{array}$ \\
\hline SUBTOTAL & & 18 & 18 & 2 & \\
\hline
\end{tabular}


INSPECTION: 15 February, 1966

B. Other Bldgs.

Time Additional New Flaking Cracks Extensions

$1002 \quad 0915$

$1001 \quad 0905$

$1000 \quad 0855$

$710 \quad 1030$

$700 \quad 1045$

$725 \quad 1105$

$726 \quad 1125$

$703 \quad 1250$

$702 \quad 1300$

$701 \quad 1315$

$752 \quad 1325$

$751 \quad 1345$

$155 \quad 1410$

$790 \quad 1650$

$160 \quad 1640$

$300 \quad 1430$

$425 \quad 1505$

$525 \quad 1630$

$550 \quad 1545$

$650 \quad 1605$

$600 \quad 0945$

$516 \quad 1515$

517

1530

SUBTOTAL

7

\section{7}

9

10

4

2

1

1

1

4

1

4

1

1

1

1

1

1

2

1

2

7

\section{1}

3

most $1 y$ W. wal1

Remarks

NE corner

$W$ end $N$, side

1

$$
S \text { side }
$$

$$
1
$$

3

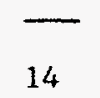

51

9
E. wall

No change $\mathrm{E}$, wall

Mostly $S \& W$ sides 
INSPECTION DATE: 16 February $1966\left(52^{\circ}-31^{\circ} \mathrm{F}, 13\right.$ knots)

PREVIOUS INSPECTION: 15 February

INTERVAL: 1 day

TOTALS: Cracks, 2; Flaking, 1; Extensions, 5

\begin{tabular}{|c|c|c|c|c|c|}
\hline A. $B O Q$ & Time & $\begin{array}{l}\text { Additional } \\
\text { Flaking }\end{array}$ & $\begin{array}{c}\text { New } \\
\text { Cracks }\end{array}$ & Extensions & Remarks \\
\hline 678 & 1100 & & & & \\
\hline 679 & 1135 & & & & \\
\hline 677 & 1150 & & & & \\
\hline 676 & 1240 & & & & \\
\hline 675 & 1310 & & & & \\
\hline 680 & 1425 & & & & \\
\hline 681 & 1330 & & & & \\
\hline 682 & 1420 & & & & \\
\hline 683 & 1410 & & & & \\
\hline 684 & 1400 & & & & \\
\hline 479 & 1625 & & & & \\
\hline 478 & 1645 & & & & \\
\hline 477 & 1700 & & & & \\
\hline 476 & 1600 & & & 1 & \\
\hline 475 & 1612 & & & & \\
\hline 484 & 1445 & & & & \\
\hline 483 & 1500 & & & & \\
\hline 482 & 1510 & & & & \\
\hline 481 & 1530 & & & & \\
\hline 480 & 1515 & & & & \\
\hline 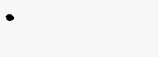 & & - & - & - & \\
\hline SUBTOTAL & & 0 & 0 & 1 & \\
\hline
\end{tabular}


INSPECTION: 16 February 1966

B. Other BIdgs.

\begin{tabular}{lcccc} 
Time & $\begin{array}{c}\text { Additional } \\
\text { Flaking }\end{array}$ & $\begin{array}{c}\text { New } \\
\text { Cracks }\end{array}$ & Extensions & Remarks \\
\hline 1600 & 1 & W side
\end{tabular}

$1002 \quad 1600$

$1000 \quad 0845$

$710 \quad 1140$

$700 \quad 1115$

$725 \quad 1210$

$726 \quad 1315$

$703 \quad 1330$

702 . 1340

$701 \quad 1345$

$752 \quad 1400$

$751 \quad 1415$

$155 \quad 1430$

790

$160 \quad 1650$

$300 \quad 1400$

$425 \quad 1450$

$525 \quad 1520$

$550 \quad 1510$

$650 \quad 1545$

$600 \quad 1040$

1

2.

$516 \quad 1600$

$517 \quad 1605$

SUBTOTAL

1

2

4 
INSPECTION DATE: 22 March $1966\left(55^{\circ}-33^{\circ} \mathrm{F}, 28\right.$ knots $)$

PREVIOUS INSPECTION DATE: 16 February $1966\left(20^{\circ} \mathrm{F}\right.$ differentials in reported daily TOTALS: Cracks, 77 ; Flaking, 30 ; Extensions, 17 . highs and in lows, gusts of 33 knots)

A. BNO Arcia

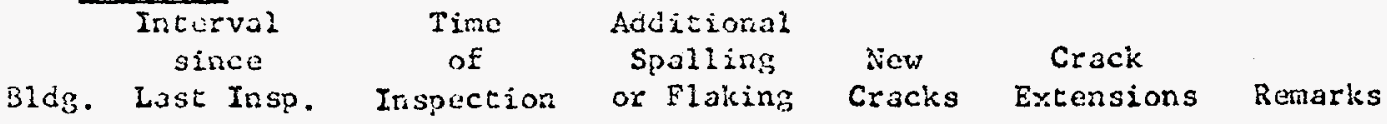

Time Additional

of Spalling New Crack

B1dg. Last Insp. Irspection or Flaking Cracks Extensions Remarks

\begin{tabular}{|c|c|c|c|c|c|c|}
\hline 078 & 34 & 0910 & 1 & 0 & 0 & \\
\hline 6.75 & $"$ & 0920 & 0 & 0 & 0 & \\
\hline 677 & $"$ & 0928 & 0 & 2 & 0 & W. Side \\
\hline 676 & $"$ & 0950 & 0 & 2 & 0 & W side \& NE corner \\
\hline 675 & $"$ & 0937 & 0 & 1 & 0 & W side \\
\hline 680 & $"$ & 1035 & 0 & 1 & 0 & W side \\
\hline 681 & 4 & 1050 & 0 & 2 & 0 & SE corner \& W side \\
\hline 682 & $1 "$ & 1025 & 0 & 1 & 0 & W side near NW corner \\
\hline 683 & $"$ & 1012 & 1 & 2 & 0 & W side \& NE overhang \\
\hline 084 & $"$ & 1000 & 0 & 1 & 0 & W side \\
\hline 479 & 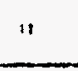 & 1515 & 0 & 3 & 0 & E side \& at SE corner \\
\hline 4.78 & " & 1455 & 1 & 0 & 1 & \\
\hline 477 & $"$ & 1300 & 0 & 0 & 0 & \\
\hline 476 & $"$ & 1415 & 2 & 1 & 0 & S side near SW corner \\
\hline 475 & $"$ & 1432 & 1 & 1 & 0 & eastern end, $\mathrm{N}$ side \\
\hline $4 \Omega 4$ & $"$ & 1115 & 2 & 1 & 0 & \\
\hline 403 & $"$ & 1100 & 1 & 0 & 0 & W side \\
\hline 482 & $"$ & 1130 & $\underline{0}$ & 0 & 0 & \\
\hline $43 i$ & $"$ & 1350 & 2 & 1 & 0 & SE corner S side \\
\hline 480 & $"$ & 1325 & 3 & 0 & 1 & \\
\hline
\end{tabular}

SUETOTAL 
IXSPECTION DATE: 22 March 1966

3. Oeinar Tusidings

Intorval

Since

Blds. Last Insp.
Tine of

Inspection
Additional

spolling or New Crack

Plak;?

Cracks Extensions Renarks

South wall starting to move

\begin{tabular}{|c|c|c|c|c|c|c|}
\hline 1002 & 34 & 1645 & 0 & 2 & 2 & to move \\
\hline 2001 & $" 1$ & 1630 & 0 & 1 & 0 & \\
\hline 1000 & $" 1$ & 1655 & 0 & 4 & 0 & \\
\hline 710 & $"$ & 1015 & 0 & 0 & 1 & \\
\hline 700 & 11 & 0955 & 1 & 1 & 1 & N side loosened up \\
\hline 725 & $" 1$ & 1055 & 0 & 3 & 0 & \\
\hline 726 & $" 1$ & 1035 & 0 & 8 & 0 & $\begin{array}{l}6 \text { cracks, south side } \\
\text { in series }\end{array}$ \\
\hline 703 & $"$ & 1305 & 0 & 2 & 0 & starting \\
\hline 392 & " & 1320 & 0 & 2 & 0 & very fine \\
\hline 701 & .1 & 1345 & 1 & 2 & 1 & \\
\hline $75 ?$ & $"$ & 1415 & 1 & 1 & 1 & \\
\hline 751 & $" 1$ & 1430 & 0 & 1 & 1 & \\
\hline 155 & $"$ & 1445 & 0 & 0 & 3 & doubtful \\
\hline 750 & $"$ & 1540 & 7 & 7 & 0 & $\begin{array}{l}\mathrm{N} \text { and } \mathrm{E} \text { sides around } \\
\mathrm{NE} \text { corner }\end{array}$ \\
\hline 160 & $"$ & 1640 & 0 & 4 & 2 & \\
\hline 30 & $"$ & 1730 & 2 & 2 & 0 & \\
\hline$\therefore 2:$ & 35 & $\begin{array}{c}23 / 3 / 66 \\
0900 \\
\end{array}$ & 0 & 7 & 0 & \\
\hline 525 & 34 & 1510 & 1 & 1 & 0 & \\
\hline 550 & $"$ & 1545 & 0 & 3 & 0 & \\
\hline 650 & $"$ & 1525 & 0 & 4 & 0 & \\
\hline 600 & 11 & 0900 & 2 & 2 & 2 & NW corner worse \\
\hline 516 & 11 & 1715 & 1 & 0 & 0 & \\
\hline 517 & 11 & 1720 & 0 & .1 & 1 & \\
\hline
\end{tabular}

SUBROTAL 
INSPECTION DATE: 13 April 1966

GERERAL WEATIIER AND TENPERATURE RANGE : $74-48^{\circ} \mathrm{F}, 9$ knots

PREVIOUS INSPECTION DATE(S): 22 March 1966

GENERAL WEATIER EXTREMES SINCE LAST INSPECTION: $35^{\circ} \mathrm{F}$ differential in reported daily TOTALS: Cracks, 49 ; Flaking, 30 ; Extensions, 18 . high and $25^{\circ}$ in daily low; A. 800 Area Interval since Time of Additional Spailing Bldg, Last Insp. Inspection or Flaking Cracks Extensions Remarks Bldg, Last Insp. Inspection or Flaking Cracks Extensions Remarks Bldg, Last Insp. Inspection or Flaking Cracks Extensions Remarks gusts of 20 knots.

\begin{tabular}{|c|c|c|c|c|c|c|}
\hline 678 & 22 days & 1300 & 1 & 3 & 0 & W. end \\
\hline 679 & $"$ & 1330 & 2 & 1 & 2 & SW and SE corners \\
\hline 677 & 4 & 1350 & 0 & 0 & 0 & $\cdot$ \\
\hline 676 & $" 1$ & 1425 & 0 & 0 & 0 & \\
\hline 675 & 11 & 1405 & 0 & 0 & 1 & East end \\
\hline 680 & $"$ & 1605 & 1 & 0 & 0 & \\
\hline 681 & $" 1$ & 1620 & 0 & 2 & 0 & \\
\hline 632 & $" 1$ & 1550 & 1 & 3 & 0 & West side \\
\hline 683 & 11 & 1530 & 0 & 3 & 0 & $\begin{array}{l}\text { East end, Severe } \\
\text { spall overhang SW c }\end{array}$ \\
\hline 634 & 11 & 1510 & 0 & 0 & 0 & \\
\hline 479 & $"$ & 1040 & 0 & 0 & 0 & \\
\hline 478 & $" 1$ & 1100 & 0 & 0 & 0 &.$\cdot$ \\
\hline 477 & $" 1$ & 1115 & 0 & 0 & 0 & \\
\hline 476 & $"$ & 1125 & 1 & 0 & 0 & Overhang NW corner \\
\hline 475 & $" 1$ & 1145 & 3 & 1 & 0 & \\
\hline 484 & 11 & 0900 & 0 & 0 & 1 & \\
\hline 483 & $"$ & 0915 & 2 & 4 & 0 & West end \\
\hline 482 & 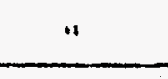 & 0935 & 0 & 0 & 0 & \\
\hline 482 & it & 0950 & 1 & 0 & 1 & West corners \\
\hline 430 & $" 1$ & 1015 & 1 & 1 & 1 & \\
\hline
\end{tabular}


INSPECTION DATE:

3. Otiar liubleinas

Interval Since Ilde. Last Insp.
Acditional

spaling or New Crack

Flaking
Cracks Extensions

Remarks

\begin{tabular}{|c|c|c|c|c|c|c|}
\hline 2002 & 22 days & 1630 & 0 & 0 & 0 & \\
\hline 1001 & $" 1$ & 1640 & 0 & 0 & 0 & \\
\hline 1000 & & 1650 & 1 & 1 & 0 & \\
\hline 710 & $: 1$ & 0935 & 0 & 1 & 0 & \\
\hline 700 & 11 & 1000 & 2 & 0 & 1 & \\
\hline 723 & $"$ & 1015 & 0 & 1 & 0 & \\
\hline 726 & $" 1$ & 1035 & 0 & 0 & 0 & $\cdot$ \\
\hline 703 & $" 1$ & 1050 & 0 & 0 & 0 & \\
\hline $70 ?$ & $" 1$ & 1100 & 0 & 0 & 1 & $1 / 2$ inch \\
\hline 701 & .1 & 1105 & 2 & 1 & 1 & $\begin{array}{l}\text { Building appears } \\
\text { Losened. }\end{array}$ \\
\hline 752 & $"$ & 1315 & 1 & 2 & 1 & \\
\hline 751 & 11 & 1330 & 0 & 1 & 2 & \\
\hline 155 & .1 & 1350 & 4 & 0 & 4 & : \\
\hline 790 & $" 1$ & 1215 & 2 & 9 & 0 & $\begin{array}{l}\text { Mult.H.I. throughout, } \\
\text { S\&W walls better shap }\end{array}$ \\
\hline $15 \hat{v}$ & $"$ & 1320 & 0 & 1 & 0 & than $N \& E$ \\
\hline 300 & 19 & 1420 & 2 & 2 & 0 & \\
\hline 423 & $u$ & 1450 & 0 & 1 & 0 & \\
\hline $32:$ & $" 1$ & 1510 & 0 & 0 & 1 & \\
\hline 530 & $"$ & 1550 & 0 & 1 & 0 & \\
\hline 650 & 11 & 1530 & 0 & 2 & 1 & \\
\hline 600 & & 0855 & 2 & 5 & 0 & Noticeable change \\
\hline 510 & $" 1$ & 1610 & 1 & 3 & 0 & \\
\hline$\$ 17$ & $" 1$ & $1620^{\circ}$ & 0 & 0 & 0 & \\
\hline
\end{tabular}


INSPECTION DATE: 14 April 1966

GEIERAL WEATHER AND TEISPRATURE RANGE : 79 - 530 F, 20 knots

PREVIDIS INSEECTION DATE(S): 13 April 1966

GEINERAL WEATHER EXTREMES SIMCE IAST INSPECTION: None

Totals: Cracks, 20; Flaking, 13 . Exiensions, 7

A. $\frac{n 00 \text { Area }}{\text { Incervol }}$

Interval

since

Tine

Bldg. Last Insp. Inspection

\begin{tabular}{llllll}
\hline 678 & 1 day & 1115 & 0 & 0 & 0 \\
\hline 679 & 1125 & 1 & 0 & 0 & Overhangs E side \\
\hline 677 & 1135 & 0 & 1 & 0 & 0 \\
\hline 676 & 1150 & 0 & 1 & 1 \\
\hline 680 & 1140 & 0 & 0 & 0 \\
\hline 681 & 1400 & 0 & 0 & 0 \\
\hline 682 & 1300 & 0 & 0 & 0 \\
\hline 683 & 1225 & 0 & 0 & 0 \\
\hline 584 & 1210 & 0 & 0 & 0 \\
\hline 479 & 1200 & 0 & 1 & 0 \\
\hline 478 & 1030 & 0 & 0 & 0 \\
\hline 477 & 1040 & 0 & 0 & 0 \\
\hline 476 & 1050 & 0 & 0 & 0 \\
\hline 475 & 1055 & 0 & 0 & 0 \\
\hline 484 & 1105 & 0 & 0 & 0 \\
\hline 483 & 0700 & 1 & 0 & 1 \\
\hline 482 & 0715 & 1 & 1 & 0 \\
\hline 481 & 0730 & 1 & 0 & 0 \\
\hline 430 & 0740 & 2 & 2 & 0 \\
\hline
\end{tabular}

SUETOTAL 
INSPECTION DATE: 14 April 1966

3. Octur Bufdings

Interval

Since

E10?.
Tine of

Inspection
Adiditional

spalliag or New Crack

Plaking Cracks Estensions Remarks

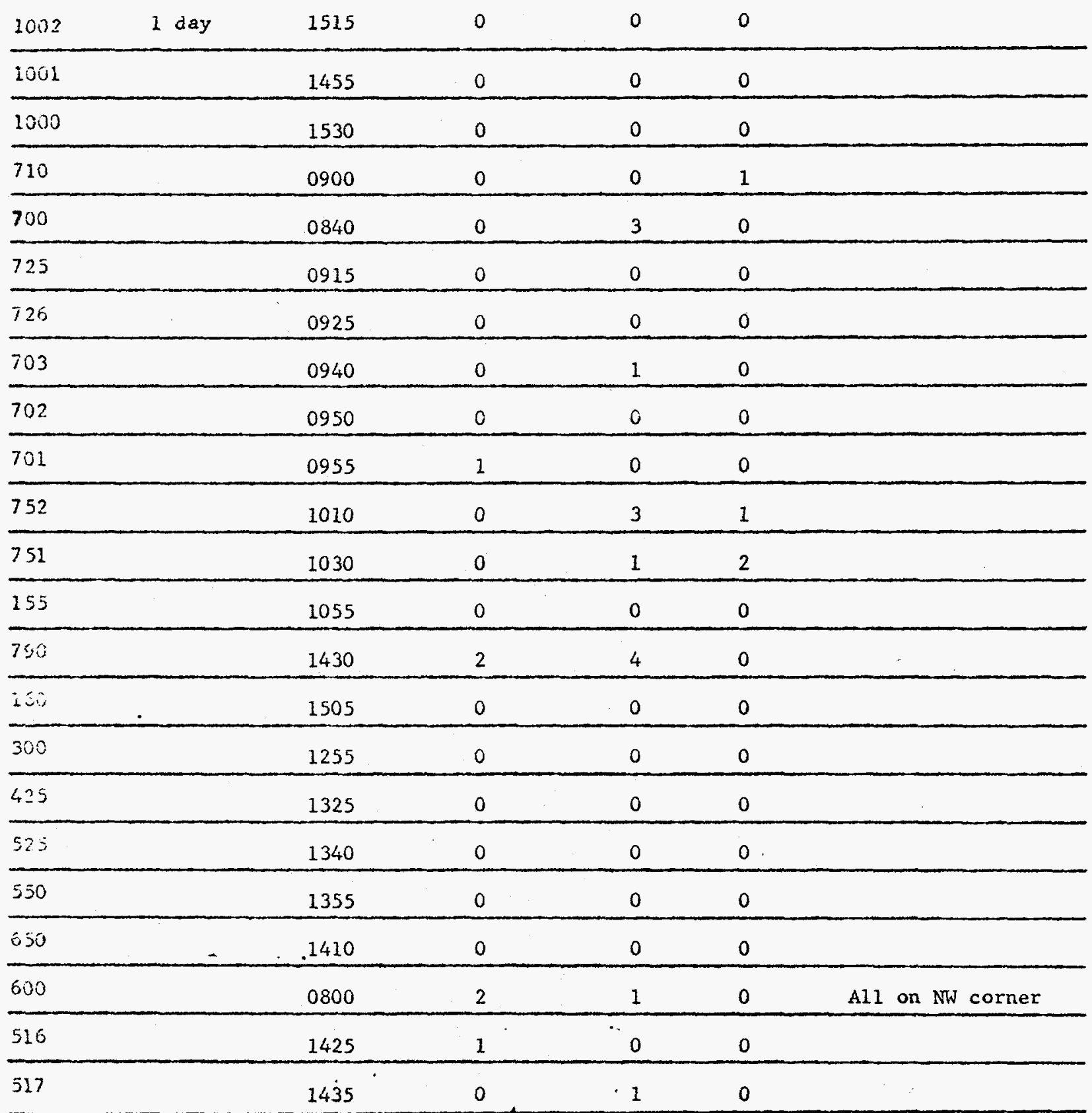

SUBTOTAL

6

14

4 
INSPECTION DATE: 20 Apri1 1966

GENERAL WEATHER AND TEMPERATURE RANGE: $61-31^{\circ} \mathrm{F}, 9$ knots

PREVIOUS INSPECTION DATE(S): 14 Apr 111966

GENERAL WEATHER EXTREMES SINCE LAST INSPECTION: See footnotes

TOTALs: Cracks, 28; Flaking, 20; Extensions, 12 .

A. BOQ Area

Interval

since

Time Additional

of Spalling

Spalling New Crack

Bldg. Last Insp

Inspection or Flaking

Cracks Extensions Remarks

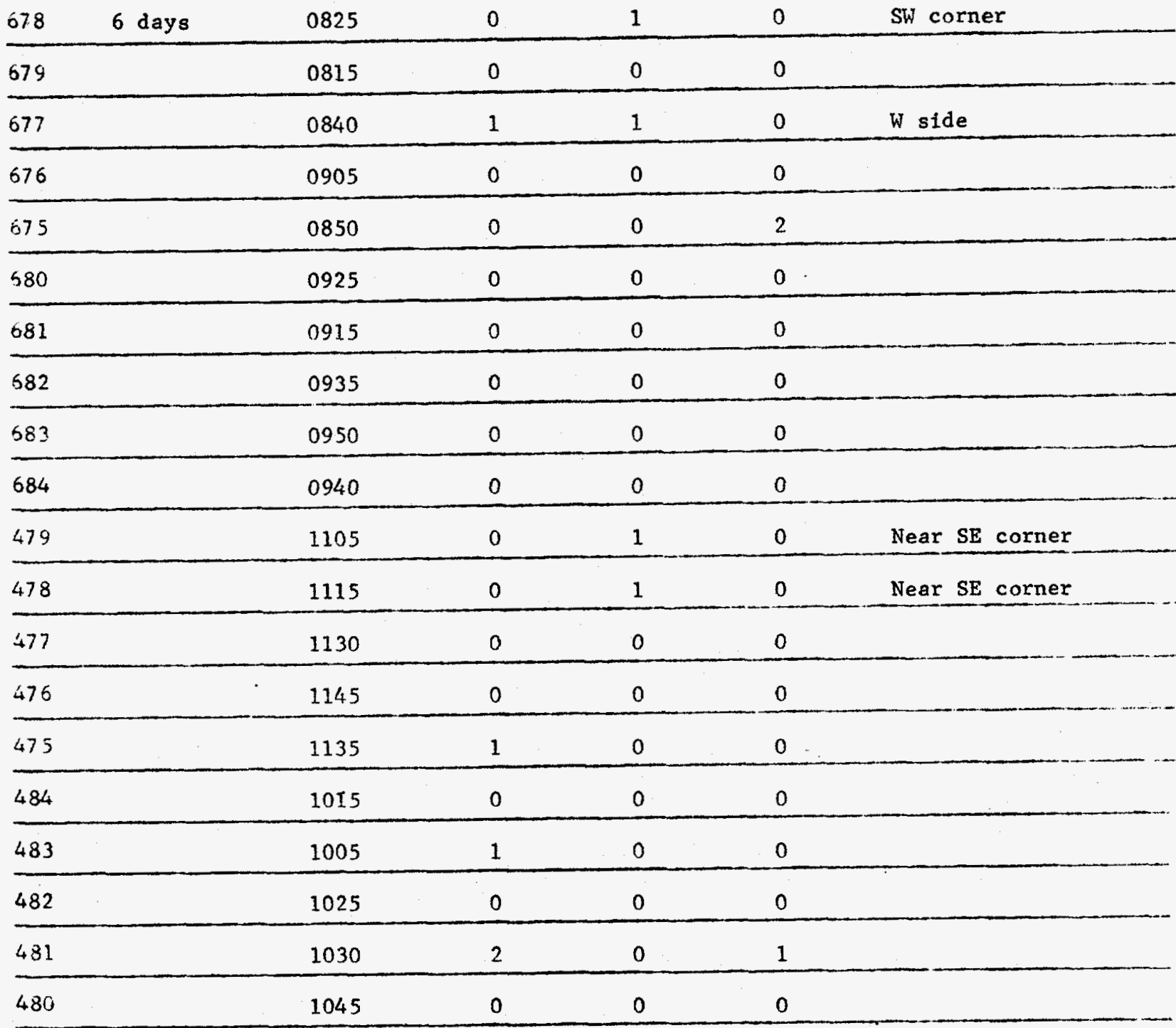

SUBTOTAL

5

4

3

1) Temperature decreased $25^{\circ} . \mathrm{F}, 17$ and 18 April; 2) Widely noted sonic boom which caused Mercury weather station barograph to instantaneously rise 0.02 inch, 19 April.

3) Gusting winds up to 36 knots from 14-19 April. 


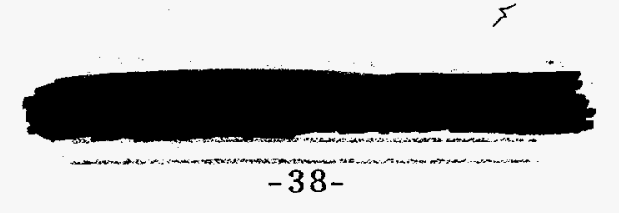

INSPECTION DATE: 20 Apr11 1966

3. Ocher Buildings

$\begin{array}{lcc}\text { Interval } & \text { Additional } \\ \text { Since } & \text { Time of } & \text { spalling or } \\ \text { ijlds. Last Insp. Inspection } & \text { Flaking } & \text { Cracks Extensions Remarks }\end{array}$

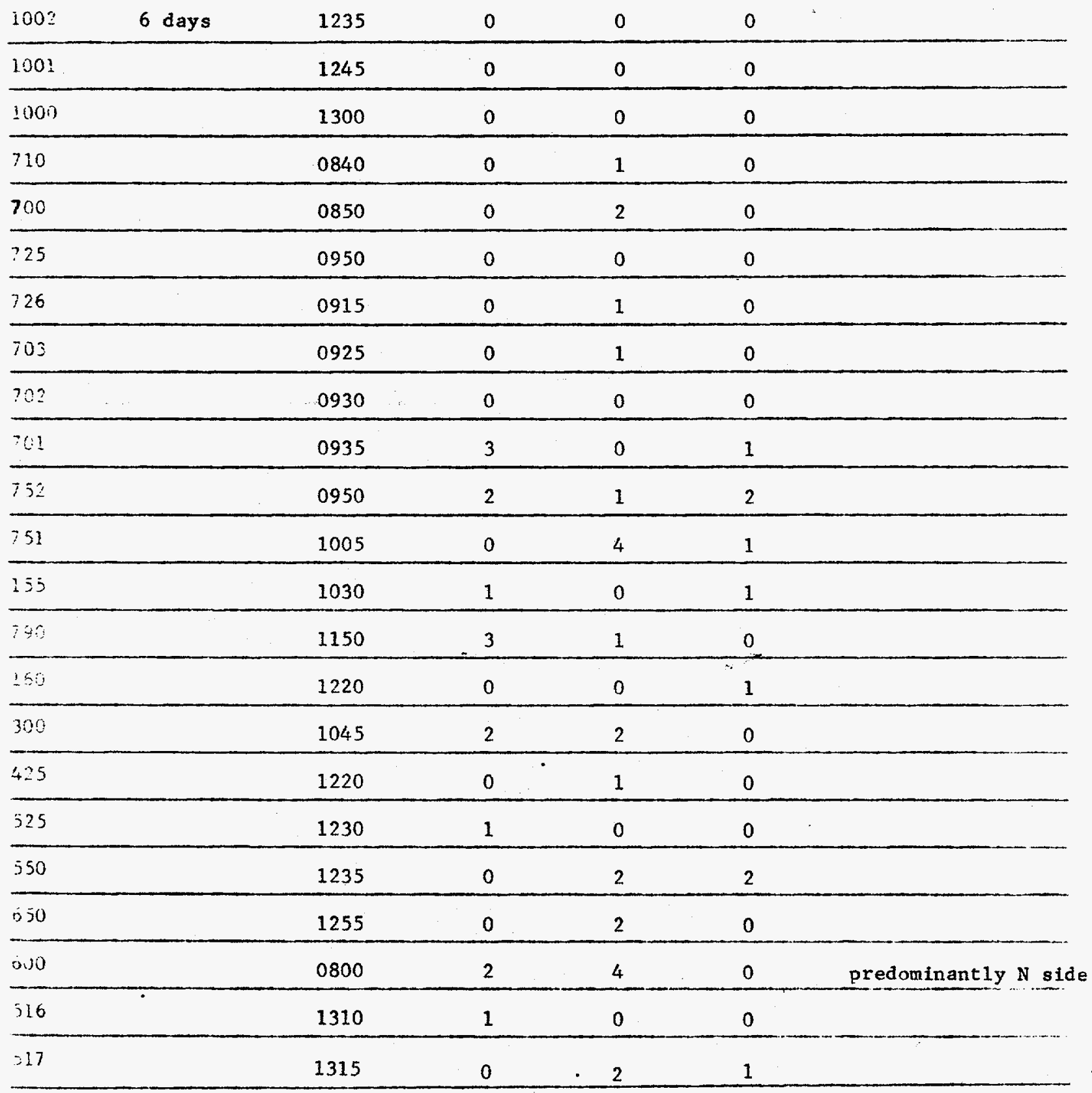

SUB TOTAL

15

24

9 
INSPECTION DATE: 26 Apri1 1966

GENERAL WEATHER AND TEMPERATURE RANGE: $83-58^{\circ} \mathrm{F}, 25$ knots

PREVIOUS INSPECTION DATE(S): 20 Apr11 1966

GENERAL WEATHER EXTREMES SINCE LAST INSPECTION: None

TOTALs: Cracks, 46 ; Flaking, 12; Extensions, 14.

A. BOQ Area

Interval

since

Time

of

Additional

Spalling

New Crack

Bldg. Last Insp. Inspection

or Flaking Cracks Extensions Remarks

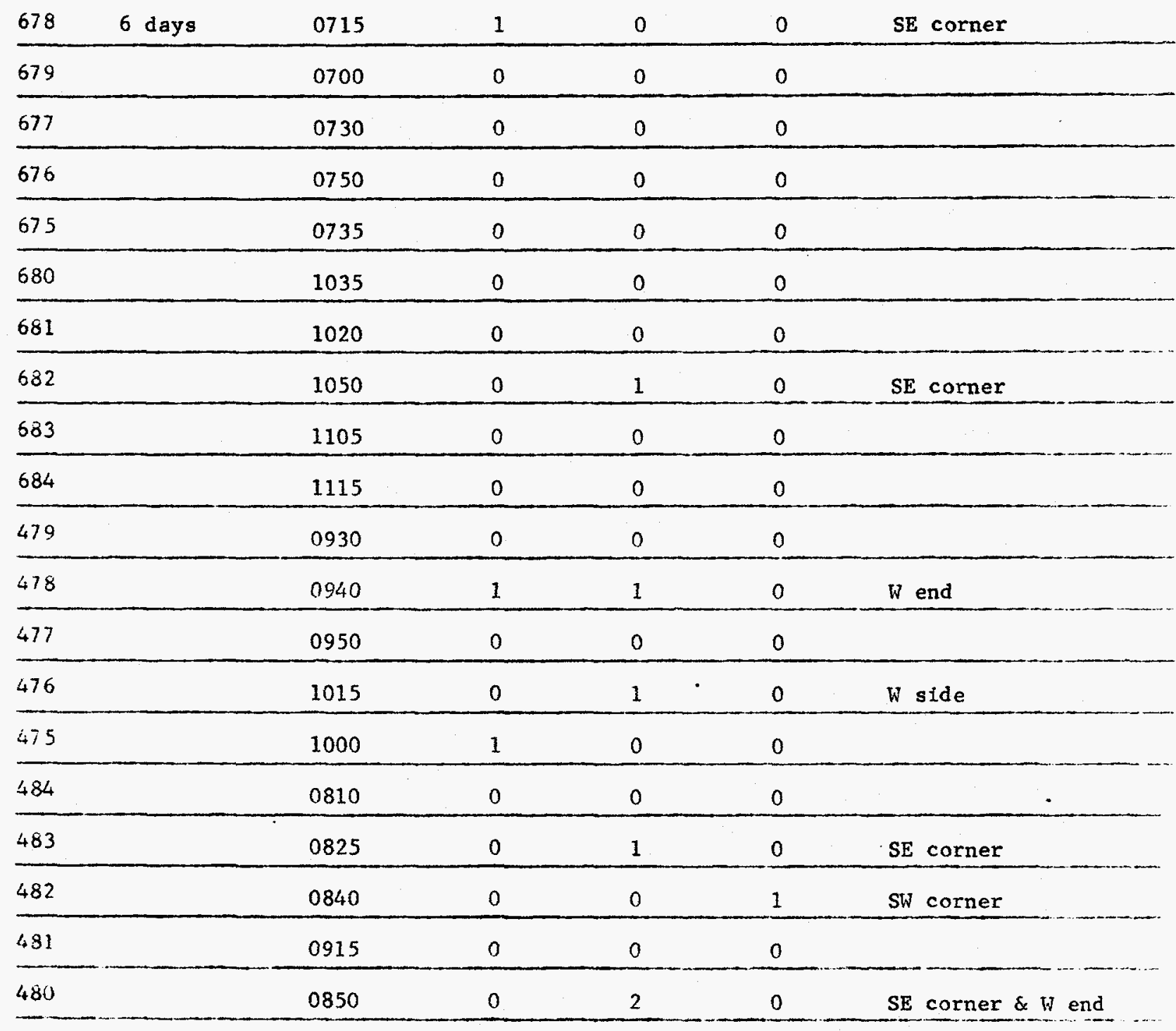

SUBTOTAL 
INSPECTION DATE: $\quad 26$ April 1966

B. Other Buildings

\begin{tabular}{|c|c|c|c|c|c|c|}
\hline Bldg. & $\begin{array}{l}\text { Interval } \\
\text { Since } \\
\text { Last Insp. }\end{array}$ & $\begin{array}{l}\text { Time of } \\
\text { Inspection }\end{array}$ & $\begin{array}{l}\text { Additional } \\
\text { spalling or } \\
\text { Flaking }\end{array}$ & $\begin{array}{c}\text { New } \\
\text { Cracks }\end{array}$ & $\begin{array}{l}\text { Crack } \\
\text { Extensions }\end{array}$ & Remarks \\
\hline 1002 & 6 days & 1345 & 0 & 0 & 0 & \\
\hline 1001 & & 1330 & 0 & 0 & 1 & \\
\hline 1000 & & 1330 & 0 & 2 & 0 & \\
\hline 710 & & 0920 & 0 & 1 & 0 & \\
\hline 700 & & 0920 & 0 & 0 & 0 & \\
\hline 725 & & 0940 & 0 & 1 & 0 & \\
\hline 726 & & 0940 & 1 & 2 & 0 & major HL and spalls \\
\hline 703 & & 1015 & 0 & 2 & 0 & \\
\hline 702 & 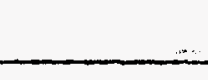 & 1005 & 0 & 0 & 0 & \\
\hline 701 & & 1005 & 0 & 1 & 3 & \\
\hline 752 & & 1035 & 0 & 5 & 3 & $\begin{array}{l}\text { W side, major } \\
\mathrm{HL} \text { and spalls }\end{array}$ \\
\hline 751 & & 1035 & 0 & 7 & 1 & \\
\hline 155 & & 1110 & 0 & 3 & 1 & \\
\hline 790 & & 1355 & 1 & 5 & 1 & \\
\hline 160 & & 1400 & 0 & 0 & 0 & \\
\hline 300 & & 1130 & 1 & 0 & 0 & \\
\hline 425 & & 1230 & 0 & 1 & 0 & \\
\hline 525 & & 1230 & 1 & 1 & 0 & 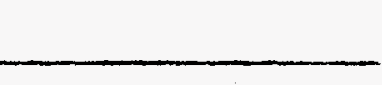 \\
\hline 550 & & 1250 & 2 & 2 & 1 & opening of old crack \\
\hline 650 & & 1250 & 0 & 3 & 2 & \\
\hline 600 & & 0845 & 3 & 1 & 0 & \\
\hline 516 & & 1430 & 0 & 2 & 0 & \\
\hline 517 & & 1435 & 0 & 1 & 0 & \\
\hline
\end{tabular}


INSPBCTION DATE: 5 May 1966

GENERAL WEATHER AND TEMPERATURE RANGE : Fair, $88^{\circ}$ to $66^{\circ} \mathrm{F}$

PREVIOUS INSPECTION DATE(S): 26 April 1966

GENERAL WEATHER EXTREMES SINCE LAST INSPECTION: Daily lows ranged from $42-69^{\circ} \mathrm{F}$; had Totals: Cracks, 19; Flaking, 13; Extensions, 12 . $\begin{aligned} & \text { wind gusts during interval } \\ & \text { of } 30 \text { knots }\end{aligned}$

A. BOQ Area

Interva 1

since

Time Additional

Spalling New Crack

B1dg. Last Iisp

Inspection or Flaking Cracks Extensions Remarks

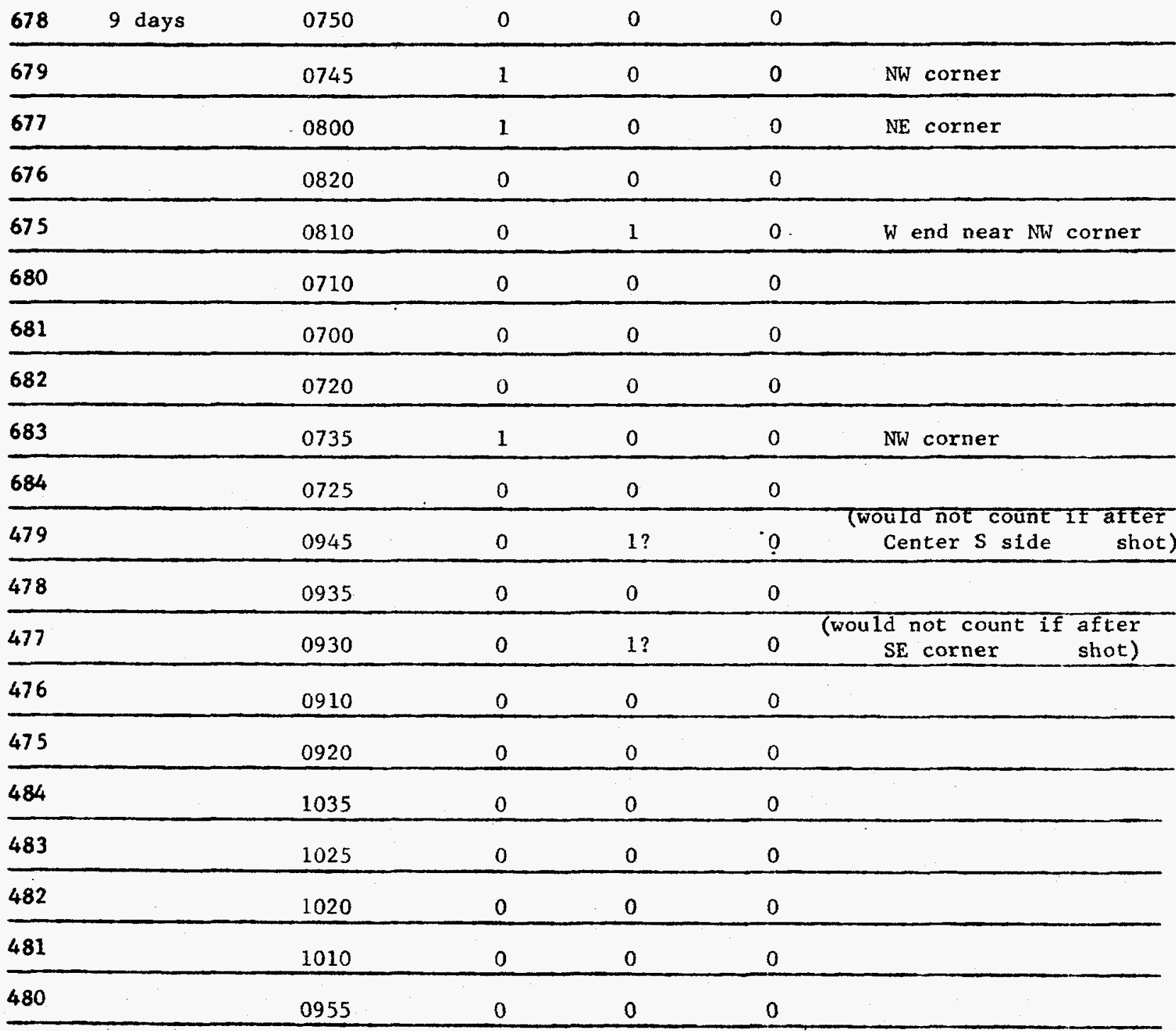

SUBTOTAL

3

3

0 
INSPECTION DATE: 5 May 1966

\section{B. Other Bulldings}

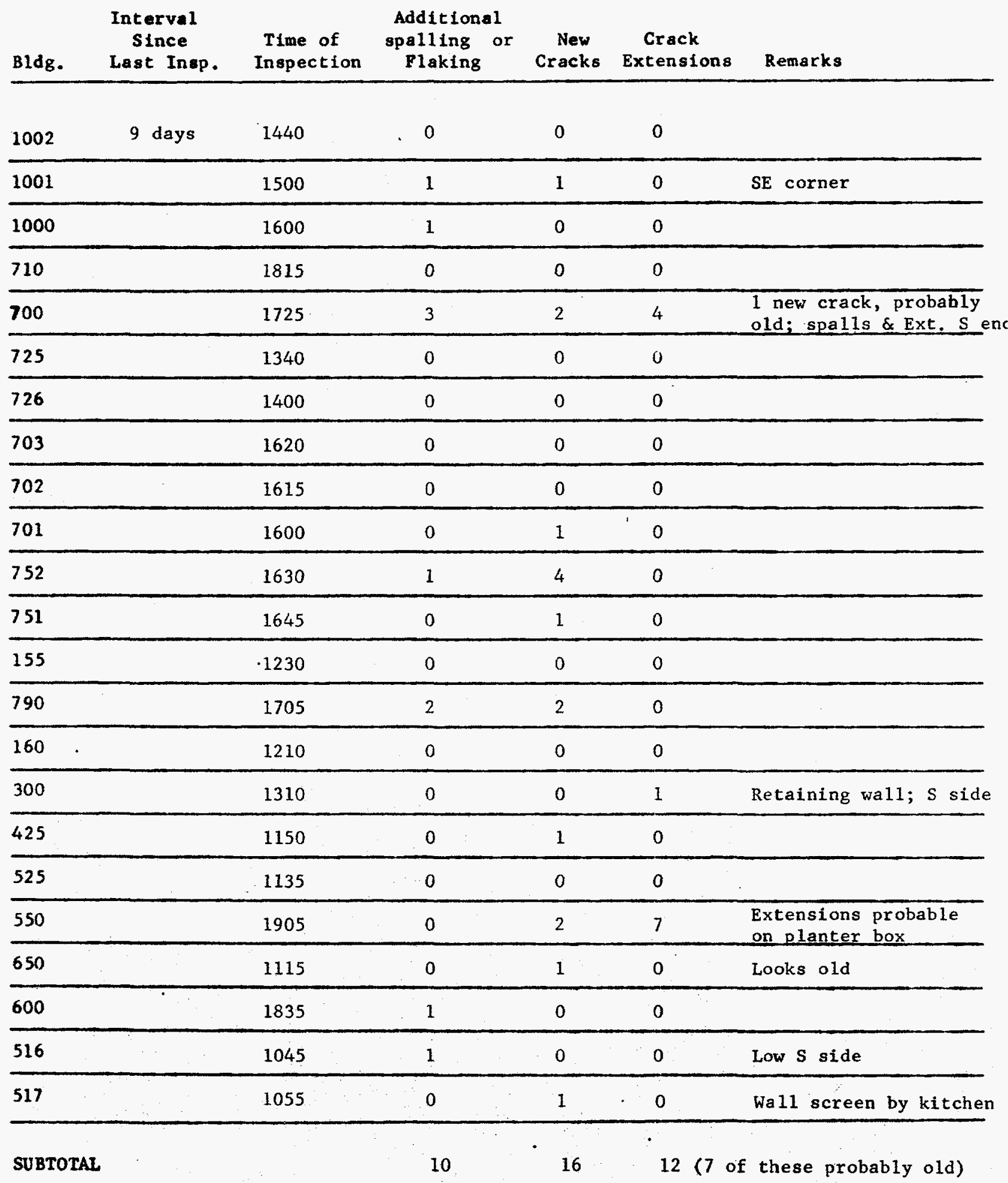


INSPECTION DATE: 6 May 1966

GENERAL WEATHER AND TEMPERATURE RANGE : Fair, $90^{\circ}-64^{\circ}$ F

PREVIOUS INSPECTION DATE(S): 5 May 1966

GENERAL WEATHER EXTREMES SINCE LAST INSPECTION: None

ToTaLs: Cracks, 37; Flaking, 13; Extensions, 10 .
A. BOQ Area
Interval
since
Time
Additional
of Spalling
B1dg. Lest Insp. Inspection
or Flaking
$\begin{array}{ccc}\text { New } & \text { Crack } & \\ \text { Cracks } & \text { Extensions } & \text { Remarks }\end{array}$

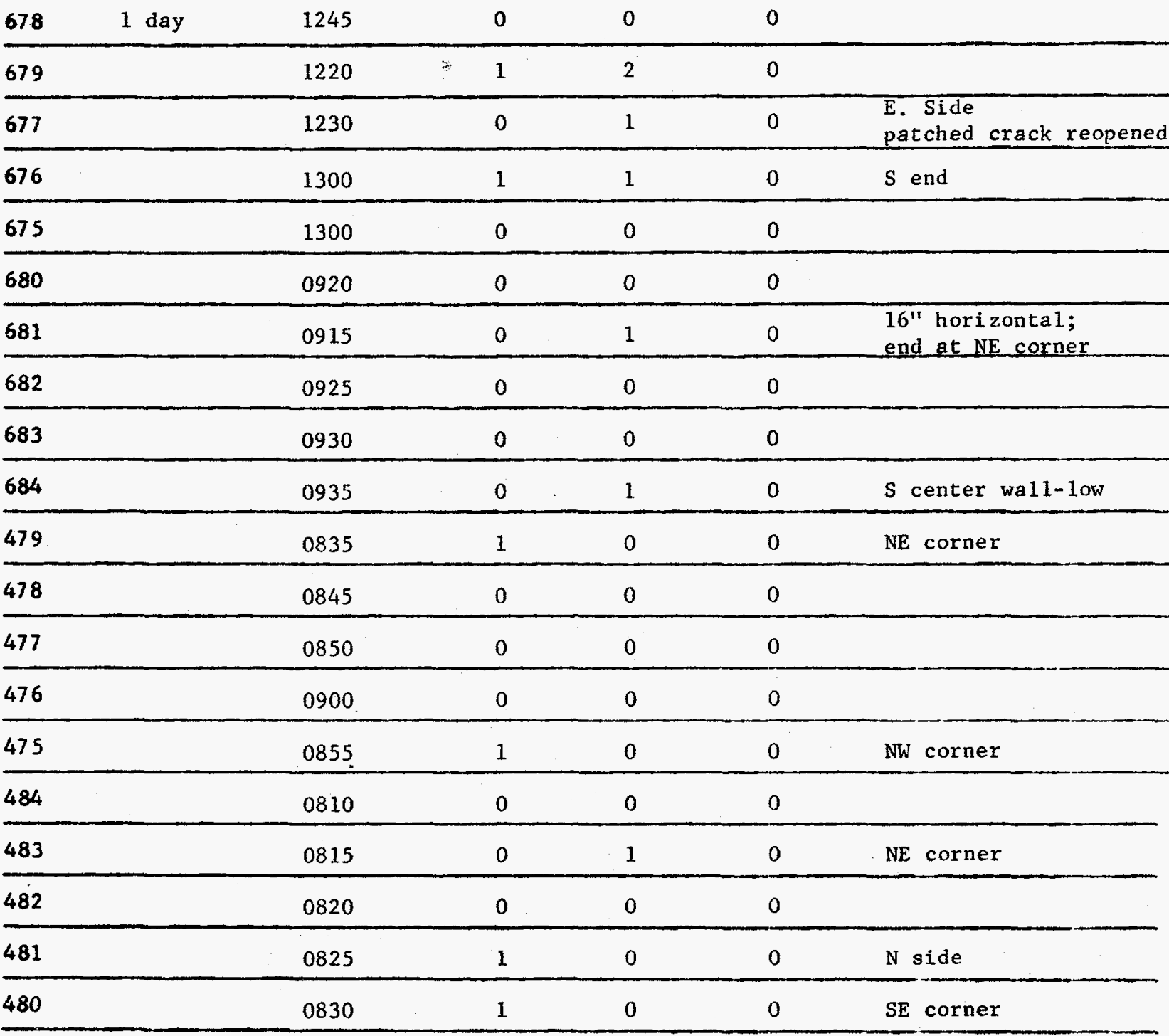

SUBTOTAL

$\begin{array}{lll}6 & 7 & 0\end{array}$


INSPBCTION DATE: 6 May 1966

B. Other Bulldings

\begin{tabular}{|c|c|c|c|c|c|c|}
\hline Bldg. & $\begin{array}{c}\text { Interval } \\
\text { Since } \\
\text { Last Insp. }\end{array}$ & $\begin{array}{l}\text { Time of } \\
\text { Inspection }\end{array}$ & $\begin{array}{l}\text { Additional } \\
\text { spalling or } \\
\text { Plaking }\end{array}$ & $\begin{array}{c}\text { New } \\
\text { Cracks }\end{array}$ & $\begin{array}{c}\text { Crack } \\
\text { Extensions }\end{array}$ & Remarks \\
\hline 1002 & 1 day & 1555 & 0 & 2 & 0 & \\
\hline 1001 & & 1545 & 0 & 0 & 0 & \\
\hline 1000 & & 1535 & 0 & 1 & $\because \quad 0$ & \\
\hline 710 & & 1630 & 0 & 0 & 0 & \\
\hline 700 & & 1645 & 4 & 3 & 0 & \\
\hline 725 & & 1700 & 0 & 0 & 0 & \\
\hline 726 & & 1615 & 0 & 3 & 1 & \\
\hline 703 & & 1500 & 0 & 0 & 0 & \\
\hline 702 & & 1530 & 0 & 0 & 0 & \\
\hline 701 & & 1545 & 1 & 3 & 1 & \\
\hline 752 & & 1420 & 0 & 4 & 0 & \\
\hline 751 & & 1445 & 0 & 3 & 0 & \\
\hline 155 & & 1420 & 1 & 1 & 0 & \\
\hline 790 & & 1500 & 0 & 3 & 2 & \\
\hline 160 & & 1430 & 0 & 0 & 0 & \\
\hline 300 & & 1405 & 0 & 0 & 0 & \\
\hline 425 & & 1400 & 0 & 0 & 0 & \\
\hline 525 & & 1345 & 0 & 0 & 0 & \\
\hline 550 & & 1330 & 0 & 1 & 1 & \\
\hline 650 & & 1325 & 0 & 2 & 5 & \\
\hline 600 & & 1340 & 0 & 4 & 0 & \\
\hline 516 & & 1630 & 1 & 0 & 0 & S. Side \\
\hline 517 & & 1610 & 0 & 0 & 0 & \\
\hline
\end{tabular}


INSPBCTION DATE: 12 May 1966

GENERAI WEATHBR AND TEMPERATURE RANGE : Fair, $73^{\circ}-44^{\circ} \mathrm{F}$

PREVIOUS INSPECTION DATE(S). 6 May 1966

GENERAI WEATHER EXTREMES SINCE LAST INSPECTION: $20^{\circ} \mathrm{F}$ variation in highs and in 1 ows during Totals: Cracks, 14; Flaking, 15; Extensions, 3 .

interval.

A. BOQ Ares

Interval
since

Time Additional

of

B1dg. Last Insp. Inspection

Spalling New Crack

or Flaking, Cracks Extensions Remarks

\begin{tabular}{|c|c|c|c|c|c|}
\hline 678 & $1700-1840$ & 0 & 0 & 0 & \\
\hline 679 & $"$ & 0 & 0 & 0 & \\
\hline 677 & $n$ & 0 & 0 & 0 & \\
\hline 676 & & 0 & 0 & 0 & \\
\hline 675 & $"$ & 0 & 0 & 0 & \\
\hline 680 & $"$ & 1 & 0 & 0 & SE corner \\
\hline 681 & $"$ & 0 & 0 & 0 & \\
\hline 682 & $" 1$ & 0 & 0 & 0 & \\
\hline 683 & $" 1$ & 0 & 0 & 0 & SW corner \\
\hline 684 & $"$ & 1 & 0 & 0 & \\
\hline 479 & $"$ & 2 & 0 & 1 & E corners \\
\hline 478 & $"$ & 0 & 0 & 0 & \\
\hline 477 & $"$ & 0 & 0 & 0 & \\
\hline 476 & $"$ & 0 & 1 & 0 & NE corner \\
\hline 475 & $"$ & 0 & 0 & 0 & \\
\hline 484 & $"$ & 0 & 0 & 0 & \\
\hline 483 & $"$ & 0 & 0 & 0 & \\
\hline 482 & $"$ & 0 & 0 & 0 & \\
\hline 481 & $"$ & 1 & 0 & 0 & W side \\
\hline 480 & "1 & $\theta$ & 0 & 0 & \\
\hline
\end{tabular}

SUBTOTAL 
INSPBCTION DATE: $\quad 12$ May 1966

B. Other Bu1ldings

\begin{tabular}{|c|c|c|c|c|c|c|}
\hline BIdg. & $\begin{array}{l}\text { Interval } \\
\text { Since } \\
\text { Last Inap. }\end{array}$ & $\begin{array}{l}\text { Time of } \\
\text { Inapection }\end{array}$ & $\begin{array}{l}\text { Additional } \\
\text { spalling or } \\
\text { Flaking }\end{array}$ & $\begin{array}{c}\text { New } \\
\text { Cracks }\end{array}$ & $\begin{array}{c}\text { Crack } \\
\text { Extensions }\end{array}$ & Remarks \\
\hline 1002 & & & 0 & 0 & 3 & \\
\hline 1001 & & 1910 & 0 & 1 & 1 & \\
\hline 1000 & & 1915 & 0 & 0 & 0 & \\
\hline 710 & & 1820 & 1 & 1 & 0 & \\
\hline 700 & & 1805 & 2 & 2 & 0 & \\
\hline 725 & & 1920 & 0 & 0 & 0 & \\
\hline 726 & & 1915 & 0 & 1 & 0 & S side \\
\hline 703 & & 1855 & 0 & 0 & 0 & \\
\hline 702 & & 1850 & 0 & 0 & 0 & \\
\hline 701 & & 1725 & 0 & 0 & 0 & \\
\hline 752 & & 1730 & 2 & 1 & 0 & $N$ side \\
\hline 751 & & 1740 & 0 & 1 & 0 & \\
\hline 155 & & 1915 & 0 & 0 & 0 & \\
\hline 790 & & 1750 & 1 & 2 & 0 & \\
\hline 160 & & 1920 & 0 & 0 & 0 & \\
\hline 300 & & 1925 & 0 & 0 & 0 & \\
\hline 425 & & 1900 & 0 & 0 & 0 & \\
\hline 525 & & 1840 & 0 & 0 & 0 & \\
\hline 550 & & 1700 & 0 & 1 & 0 & Planter Box \\
\hline 650 & & 1835 & 0 & 1 & 1 & $\begin{array}{l}\text { I block, continuing } \\
\text { in bad shape }\end{array}$ \\
\hline 600 & & 1955 & 3 & 2 & 0 & w/spa11ing \\
\hline 516 & & 1905 & 1 & 0 & 0 & \\
\hline 517 & & 1905 & 0 & 0 & 0 & \\
\hline
\end{tabular}


INSPECTION DATE: 13 May 1966

GENERAL WEATHER AND TEMPERATURE RANGE : Fair, $75^{\circ}-50^{\circ} \mathrm{F}$

PREVIOUS INSPECTION DATE(S): 12 May, 1966

GENERAI WEATHER EXTREMRS SINCE LAST INSPECTION: None

Totals: Cracks, 28; Flaking, 22; Extensions, 3

A. BOQ Area

Interval

since

Time Additional

of Spalling New Crack

B1dg. Last Insp. Inspection or Flaking Cracks Extensions Remarks

678

1 day

1140

0

0

679

1135

0

0

677

1125

0

676

1115

0

675

1120

0

0

680

68

1215

0

0

682

1210

0

0

683

1200

$0 \quad 0$

684

1150

\begin{tabular}{llll} 
& 0 & 0 & 0 \\
\hline 150 & 0 & 0 & 0
\end{tabular}

\begin{tabular}{lllll}
684 & 1155 & 0 & 0 & 0 \\
\hline 479 & 1025 & 0 & 1 & 1 \\
\hline 478 & 1020 & 0 & 0 & 0 \\
\hline 477 & 1015 & 0 & 0
\end{tabular}

\begin{tabular}{lllll}
477 & 1015 & 0 & 0 & 0 \\
\hline 476 & 1005 & 0 & 0 & 0 \\
\hline 475 & 1000 & 0 & 0
\end{tabular}

\begin{tabular}{lllll}
\hline 475 & 1000 & 0 & 0 & 0 \\
\hline 484 & 1055 & 0 & 0 & 0
\end{tabular}

\begin{tabular}{lllll}
\hline 484 & 1055 & 0 & 0 & 0 \\
\hline 483 & 1100 & 2 & 0 & 0 \\
\hline 482 & 1045 & 0 & 0
\end{tabular}

482

104

\section{1}

1040

480

1035

0

0

SUBTOTAL

4

$\begin{array}{lll}1 & 1 & 0 \\ 1 & 1 & 0\end{array}$

$\begin{array}{lll}4 & 3 & 1\end{array}$


B. Other Buildings

\begin{tabular}{|c|c|c|c|c|c|c|}
\hline Bldg. & $\begin{array}{c}\text { Interval } \\
\text { Since } \\
\text { Last Insp. }\end{array}$ & $\begin{array}{l}\text { Time of } \\
\text { Inspection }\end{array}$ & $\begin{array}{l}\text { Additional } \\
\text { spalling or } \\
\text { Plaking }\end{array}$ & $\begin{array}{c}\text { New } \\
\text { Cracks }\end{array}$ & $\begin{array}{c}\text { Crack } \\
\text { Extensions }\end{array}$ & Remarks \\
\hline 1002 & 1 day & 1015 & 0 & 1 & 0 & major step; W side \\
\hline 1001 & & 1005 & 0 & 0 & 0 & \\
\hline 1000 & & 0950 & 0 & 0 & 0 & \\
\hline 710 & & 1020 & 0 & 0 & 1 & \\
\hline 700 & & 1030 & 1 & 2 & 0 & $\mathrm{~W}$ and $\mathrm{N}$ side \\
\hline 725 & & 1900 & 0 & 0 & 0 & \\
\hline 726 & & 1630 & 0 & 2 & 0 & \\
\hline 703 & & 1600 & 0 & 1 & 0 & SE corner \\
\hline 702 & & 1620 & 0 & 0 & 0 . & \\
\hline 701 & & 1245 & 1 & 2 & 0 & \\
\hline 752 & & 0850 & 1 & 5 & 0 & $\mathrm{~N}$ and $\mathrm{W}$ sides \\
\hline 751 & & 1040 & 2 & 3 & 0 & Al1 thru blocks \\
\hline 155 & & 1540 & 0 & 0 & 0 & \\
\hline 790 & & 1110 & 3 & 2 & 0 & $\mathrm{~N}$ side \\
\hline 160 & & 1525 & 0 & 0 & 0 & ' \\
\hline 300 & & 1725 & 4 & 0 & 0 & retaining walls \\
\hline 425 & & 1505 & 0 & 1 & 0 & \\
\hline 525 & & 1450 & 0 & 0 & 0 & \\
\hline 550 & & 1430 & 0 & 3 & 0 & \\
\hline 650 & & 1130 & 1 & 2 & 1 & Most on $W$ side \\
\hline 600 & & 1300 & 5 & 1 & 0 & 1 new w/spall \\
\hline 516 & & 1905 & 0 & 0 & 0 & \\
\hline 517 & & 1850 & 0 & 0 & 0 & \\
\hline
\end{tabular}


INSPECTION DATE: 18 May 1966

GENERAL WEATHER AND TEMPERATURE RANGE : Fair, $89^{\circ}-69^{\circ} \mathrm{F}$

PREVIOUS INSPECTION DATE(S): 13 MaY 1966

GENRRAL WEATHER EXTREMES SINCE LAST INSPECTION: $15^{\circ} \mathrm{F}$ variation in highs and in lows

rotals: Cracks, 11 ; Flaking, 25; Extensions, 3 .

A. BOQ Area

Interval

since

Time Additional

Bldg. Last Insp

of Spalling or Flaking

New Crack

Cracks Extensions Remarka

\begin{tabular}{|c|c|c|c|c|c|}
\hline $678 \quad 5$ days & 1000 & 0 & 0 & 0 & \\
\hline 679 & 1030 & 1 & 1 & 0 & \\
\hline 677 & 1240 & 1 & 0 & 0 & \\
\hline 676 & 1255 & 0 & 0 & 0 & inside worse than out. \\
\hline 675 & 1105 & 1 & 0 & 0 & \\
\hline 680 & 1310 & 1 & 1 & 0 & \\
\hline 681 & 1330 & 1 & 0 & 0 & \\
\hline 682 & 1345 & 0 & 0 & 0 & \\
\hline 683 & 1400 & 0 & 0 & 0 & \\
\hline 684 & 1415 & 1 & 0 & 0 & \\
\hline 479 & 1445 & 1 & 0 & 0 & \\
\hline 478 & 1505 & 1 & 0 & 0 & \\
\hline 477 & 1518 & 1 & 0 & 0 & \\
\hline 476 & 1550 & 1 & 1 & 0 & \\
\hline 475 & 1535 & 2 & 0 & 1 & 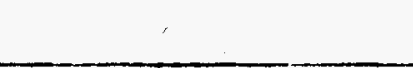 \\
\hline 484 & 1705 & 0 & 0 & 0 & \\
\hline 483 & 1635 & 0 & 0 & 0 & . \\
\hline 482 & 1650 & 1 & 0 & 0 & \\
\hline 481 & 1720 & 1 & 0 & 0 & \\
\hline 480 & 1615 & 1 & 0 & 0 & \\
\hline
\end{tabular}


INSPECTION DATE: 18 May 1966

\section{B. Other Buildings}

\begin{tabular}{|c|c|c|c|c|c|c|}
\hline B1dg. & $\begin{array}{l}\text { Interval } \\
\text { Since } \\
\text { Last Insp. }\end{array}$ & $\begin{array}{l}\text { Time of } \\
\text { Inspection }\end{array}$ & $\begin{array}{l}\text { Additional } \\
\text { spalling or } \\
\text { Flaking }\end{array}$ & $\begin{array}{c}\text { New } \\
\text { Cracks }\end{array}$ & $\begin{array}{c}\text { Crack } \\
\text { Extensions }\end{array}$ & Remarks \\
\hline 1002 & 5 days & 1440 & 0 & 0 & 0 & \\
\hline 1001 & & 1445 & 1 & 1 & 0 & \\
\hline 1000 & & 1450 & 0 & 0 & 0 & 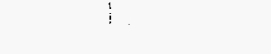 \\
\hline 710 & & 1435 & 0 & 0 & 0 & \\
\hline 700 & & 1420 & 1 & 1 & 0 & \\
\hline 725 & & 1500 & 0 & 0 & 0 & \\
\hline 726 & & & 0 & 0 & 0 & \\
\hline 703 & & 0935 & 0 & 0 & 0 & \\
\hline 702 & & 0945 & 0 & 0 & 0 & \\
\hline 701 & & 1515 & 1 & 0 & 0 & \\
\hline 752 & & 1525 & 0 & 0 & 0 & \\
\hline 751 & & 1534 & 1 & 0 & 0 & \\
\hline 155 & & 0950 & 0 & 2 & 0 & 1 probably old \\
\hline 790 & & 1355 & 3 & 0 & 0 & \\
\hline 160 & & 1000 & 0 & 1 & 2 & \\
\hline 300 & & 1005 & 0 & 0 & 0 & \\
\hline 425 & & 1030 & 1 & 0 & 0 & \\
\hline 525 & & 1040 & 0 & 0 & 0 & \\
\hline 550 & & 1630 & 1 & 1 & 0 & \\
\hline 650 & & 1615 & 0 & $1 ?$ & 0 & \\
\hline 600 & & No rec & rd of inspect & ion & & \\
\hline 516 & & 1705 & 1 & 0 & 0 & $\therefore$ \\
\hline 517 & & 1710 & 0 & 1 & 0 & \\
\hline
\end{tabular}


INSPBCTION DATE: 19 May 1966

GENERAL WEATHER AND TEMPERATURE RANGE: Fair, $92^{\circ}-61^{\circ} \mathrm{F}$

PREVIOUS INSPECTION DATE(S): 18 May 1966

GBNERAL WEATHER EXTREMES SINCE LAST INSPECTION: None

Totals: Cracks, 9 ; Flaking, 28; Extensions, 1 .

A. BOQ Area

Interva 1

Time Add1tional

since

of Spailing

New Crack

B1dg. Last Insp. Inspection

or Flaking Cracks Extensfons Remarks

\begin{tabular}{|c|c|c|c|c|c|}
\hline $678 \quad 1$ day & 0800 & 1 & 0 & 0 & \\
\hline 679 & 0812 & 0 & 0 & 0 & \\
\hline 677 & 0825 & 2 & 1 & 0 & w/new spalls \\
\hline 676 & 0835 & 1 & 0 & 0 & \\
\hline 675 & 0847 & 0 & 0 & 0 & \\
\hline 680 & 0750 & 1 & 0 & 0 & \\
\hline 681 & 0705 & 1 & 0 & 0 & \\
\hline 682 & 0715 & 0 & 0 & 0 & \\
\hline 683 & 0740 & 1 & 0 & 0 & \\
\hline 684 & 0725 & 0 & 0 & 0 & 1 new t.h.1. not \\
\hline 479 & 0940 & 1 & 1 & 0 & \\
\hline 478 & 0900 & 0 & 0 & 0 & \\
\hline 477 & 0910 & 0 & 0 & 0 & \\
\hline 476 & 0930 & 0 & 0 & 0 & \\
\hline 475 & 0920 & 0 & 0 & 0 & \\
\hline 484 & 1020 & 0 & 0 & 0 & \\
\hline 483 & 1030 & 1 & 0 & 0 & \\
\hline 482 & 1007 & 0 & 0 & 0 & \\
\hline 481 & 0955 & 2 & 0 & 0 & \\
\hline 480 & 1045 & 0 & 0 & 0 & \\
\hline
\end{tabular}

SUBTOTAL

11

2

0 
INSPECTION DATE: 19 May 1966

B. Other Butldings

\begin{tabular}{|c|c|c|c|c|c|c|}
\hline Bldg. & $\begin{array}{l}\text { Interval } \\
\text { SInce } \\
\text { Last Insp. }\end{array}$ & $\begin{array}{l}\text { Time of } \\
\text { Inspection }\end{array}$ & $\begin{array}{l}\text { Additional } \\
\text { spalling or } \\
\text { Plaking }\end{array}$ & $\begin{array}{c}\text { New } \\
\text { Cracks }\end{array}$ & $\begin{array}{c}\text { Crack } \\
\text { Extenatons }\end{array}$ & Remarka \\
\hline 1002 & i day & 1336 & 0 & 0 & 0 & \\
\hline 1001 & & 1340 & 0 & 1 & 0 & \\
\hline 1000 & & 1345 & 0 & 0 & 0 & \\
\hline 710 & & 1350 & 0 & 2 & 0 & \\
\hline 700 & & 1405 & 1 & 0 & 0 & \\
\hline 725 & & 1337 & 1 & 0 & 0 & \\
\hline 726 & & 1325 & 0 & 0 & 0 & 1 H1 not really \\
\hline 703 & & 1340 & 0 & 0 & 0 & \\
\hline 702 & & 1330 & 0 & 0 & 0 & \\
\hline 701 & & 1333 & 0 & 0 & 0 & \\
\hline 752 & & 1310 & 2 & 0 & 1 & \\
\hline 751 & & 1250 & 0 & 1 & 0 & \\
\hline 155 & & 1305 & 0 & 0 & 0 & \\
\hline 790 & & 1100 & 5 & 1 & 0 & \\
\hline 160 & & 1125 & 0 & 0 & 0 & \\
\hline 300 & & 1230 & 3 & 0 & 0 & \\
\hline 425 & & & Not inspected & & & \\
\hline 525 & & 1425 & 0 & 0 & 0 & paint flaking \\
\hline 550 & & 1407 & 0 & 0 & 0 & \\
\hline 650 & & 1410 & 0 & 0 & 0 & \\
\hline 600 & & 1245 & 2 & 0 & 0 & $\begin{array}{l}\text { Probably four new } \\
\text { spalling areas }\end{array}$ \\
\hline 516 & & 1400 & 3 & 1 & 0 & \\
\hline 517 & & 1352 & 0 & 1 & 0 & \\
\hline
\end{tabular}




$$
-53-
$$

APPENDIX B

Photographs in this section depict typical Mercury structures and cracking. Peak particle velocity, where indicated, was measured at Quonset 25.

\author{
Figures B-1 to B-4 Typical Mercury structures \\ Figure B-5 Typical new dormitory crack, 1 Dec. 1965 \\ Figures B-6 to B- 8 Cracking after $0.18 \mathrm{~cm} / \mathrm{sec}$ \\ Figures B-9 to B-14 Cracking after $0.21 \mathrm{~cm} / \mathrm{sec}$ \\ Figures B-15 to B-19 Cracking after $0.13 \mathrm{~cm} / \mathrm{sec}$ \\ Figures B-20 to B-25 Cracking after 28-day interval of no \\ significant seismic motion
}




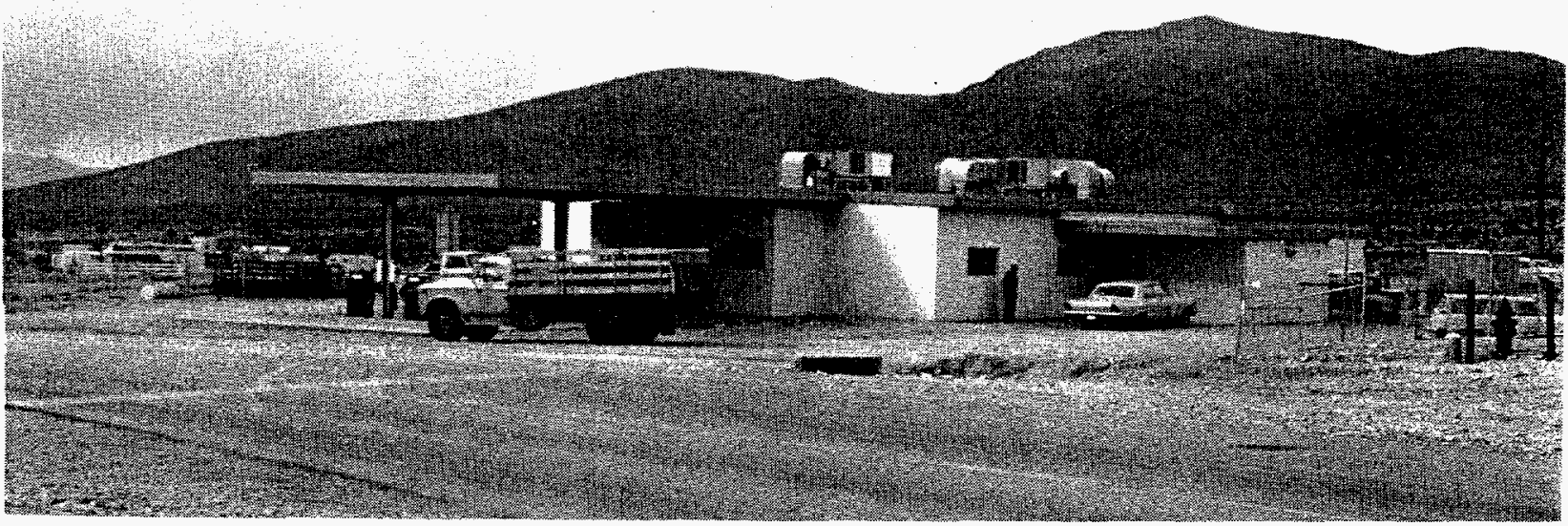

Fig. B-1. Typical Mercury masonry construction.

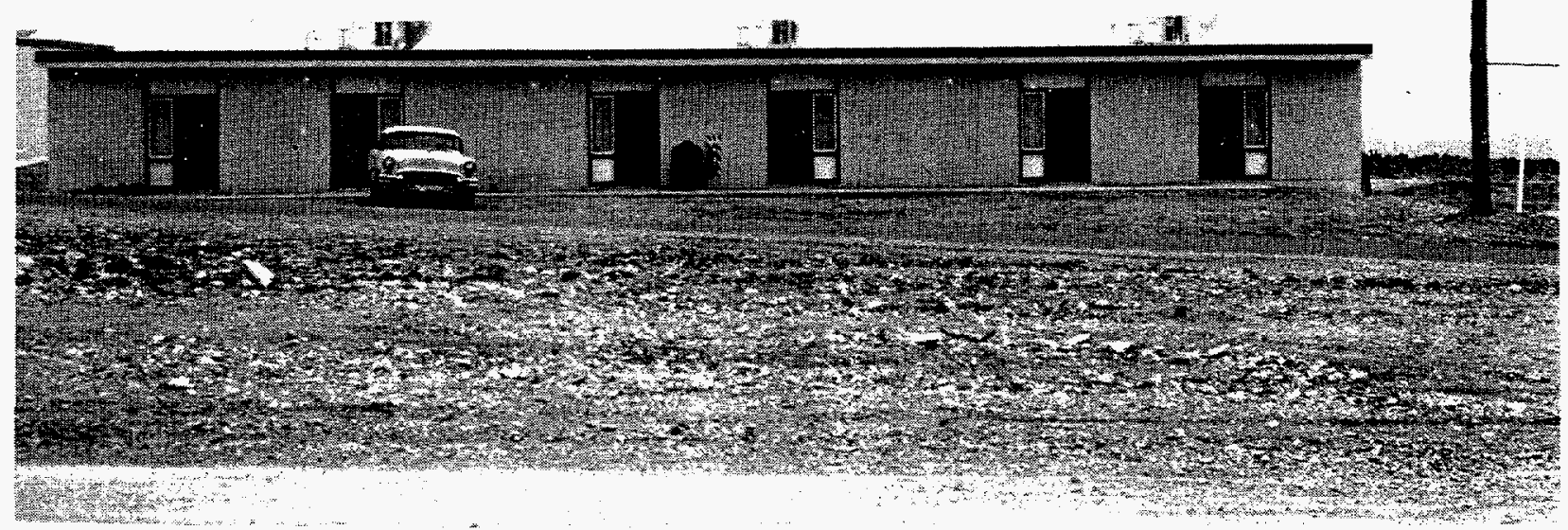

Fig. B-2. Typical Mercury dormitory. 


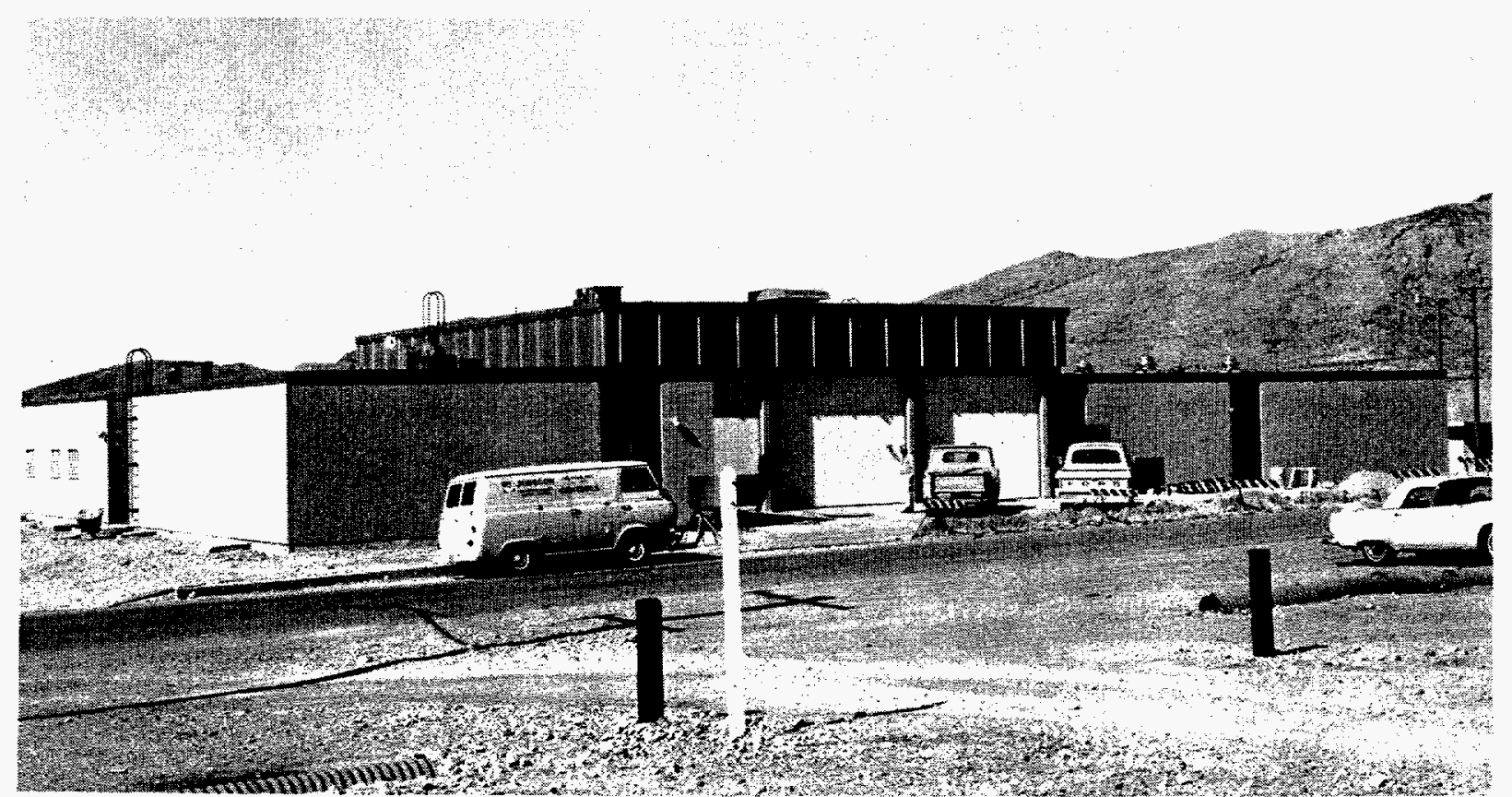

Fig. B-3. New fire house, Building 425 .

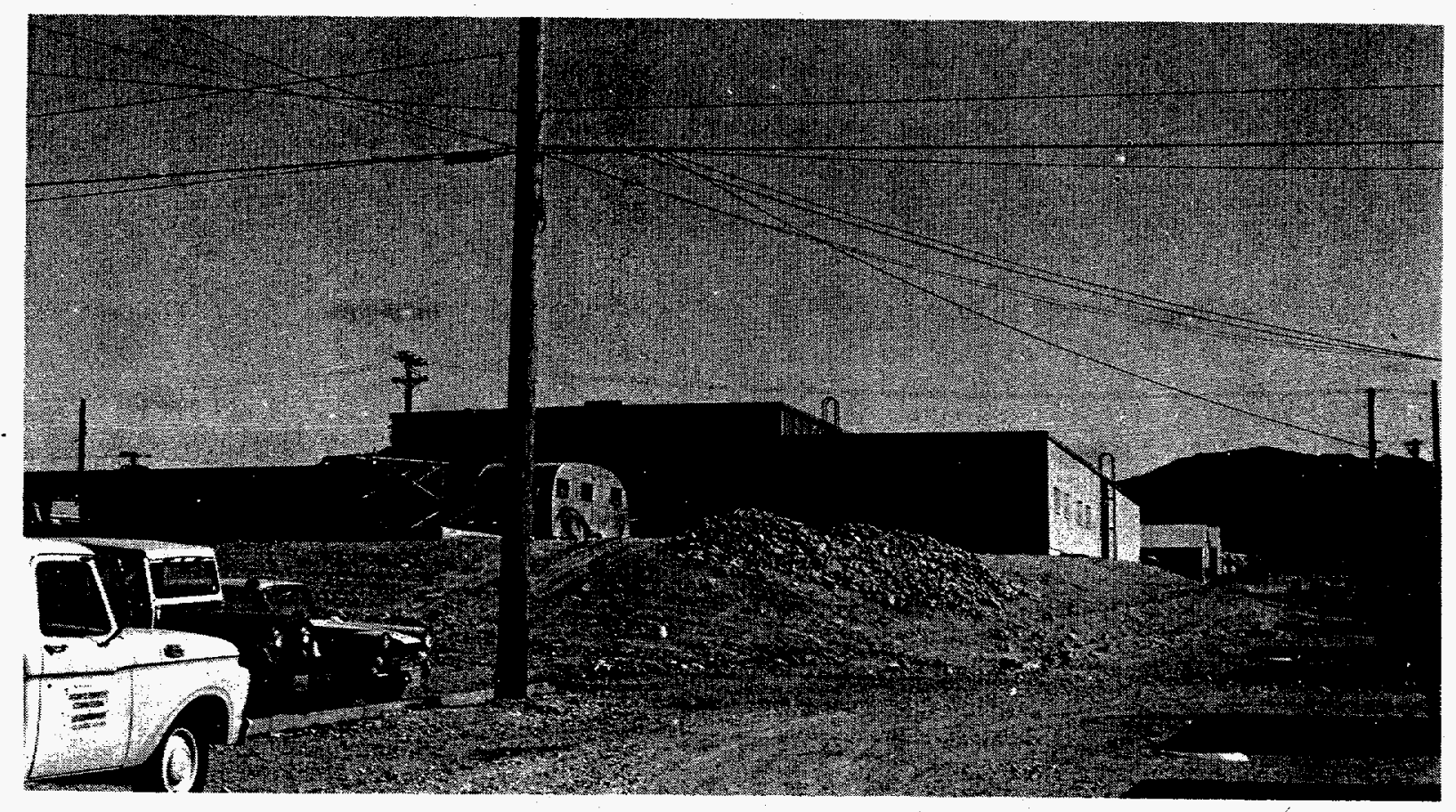

Fig. B-4. Building 425, from rear showing contour. 
$-56-$

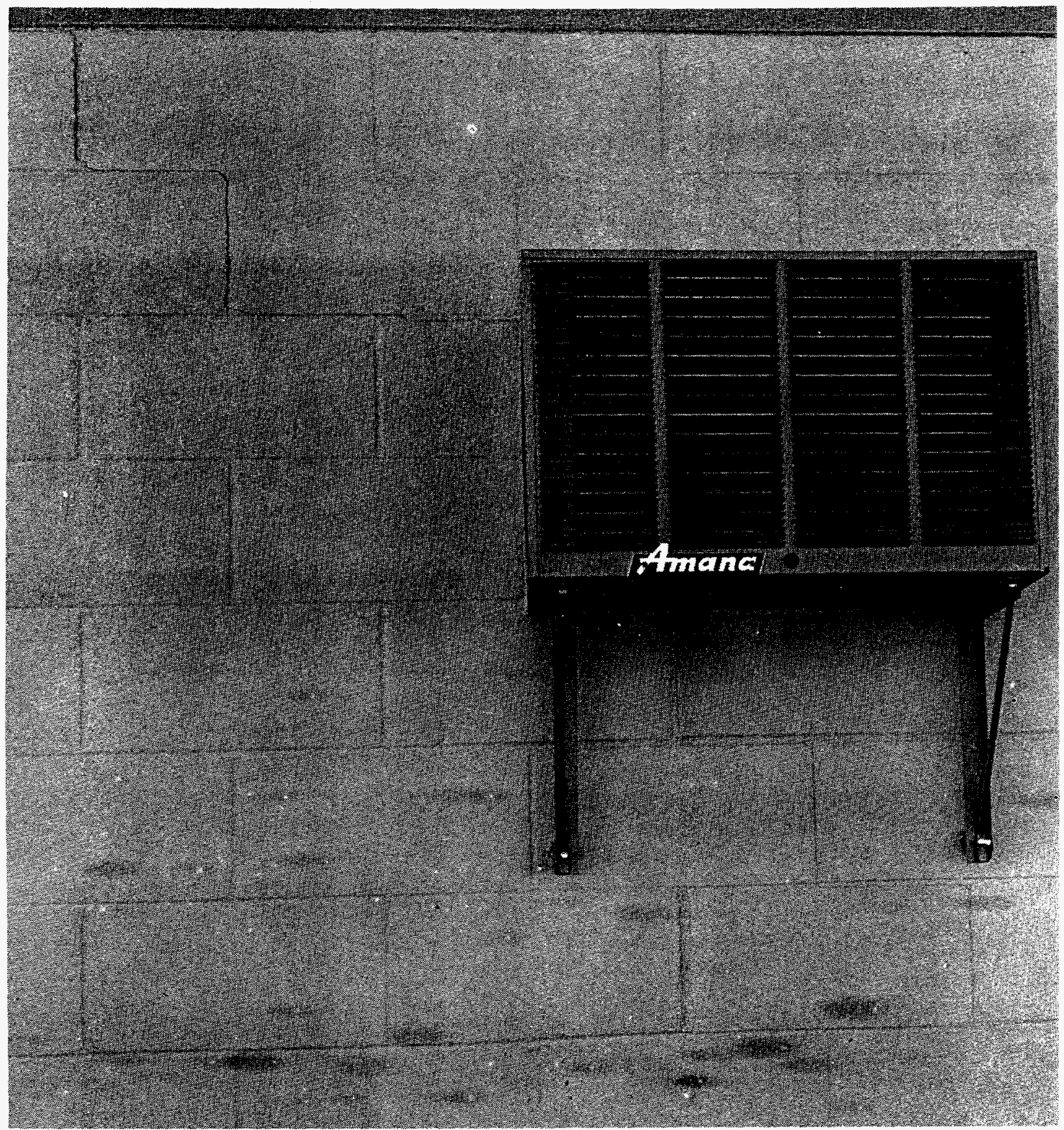

Fig. B-5. Typical existing crack, 1 Dec. 1965. 


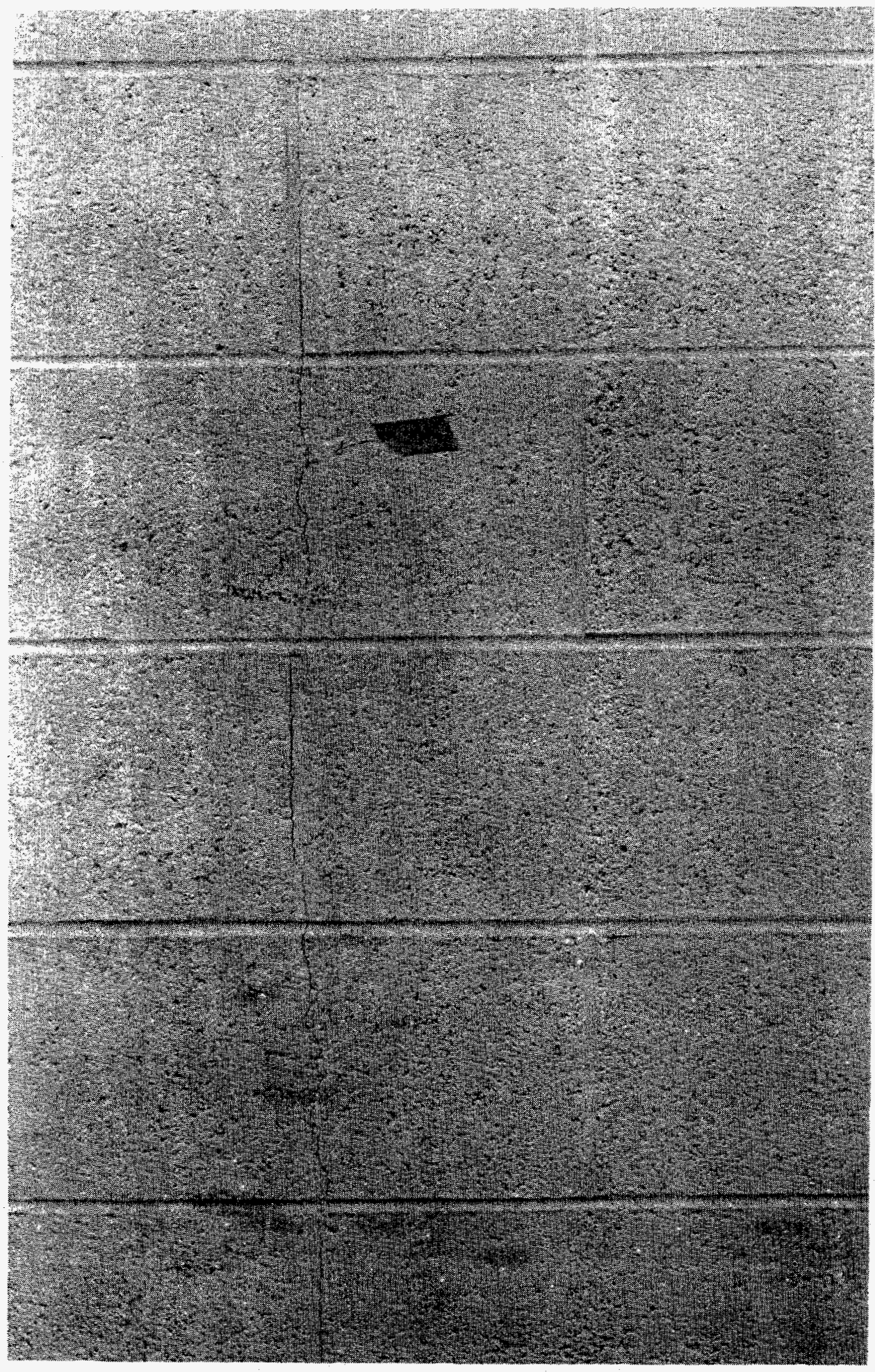

Fig. B-6. Building 751, north side, $0.18 \mathrm{~cm} / \mathrm{sec}$. 


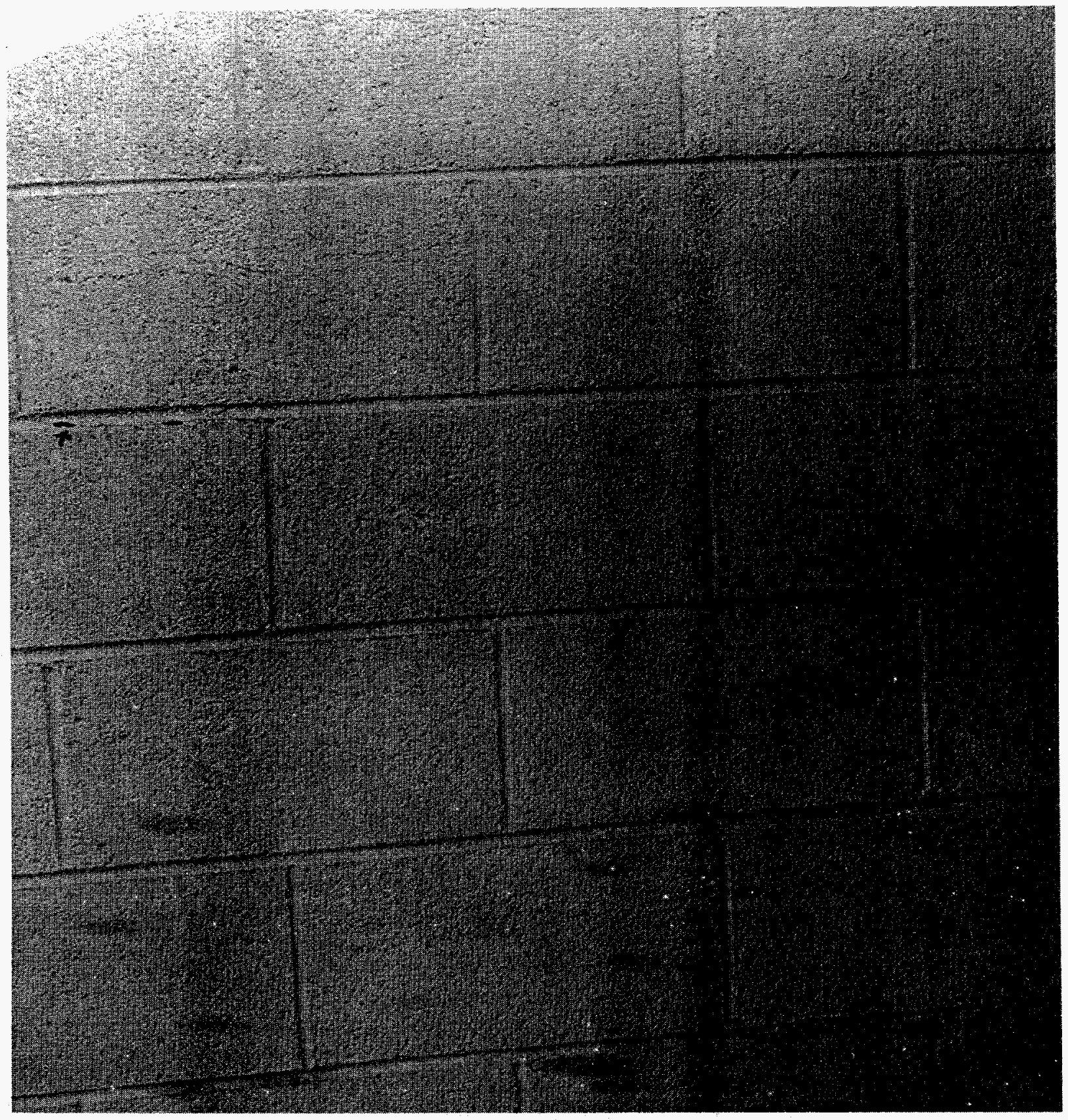

Fig. B-7. Building. 681 , west end, $0.18 \mathrm{~cm} / \mathrm{sec}$. 


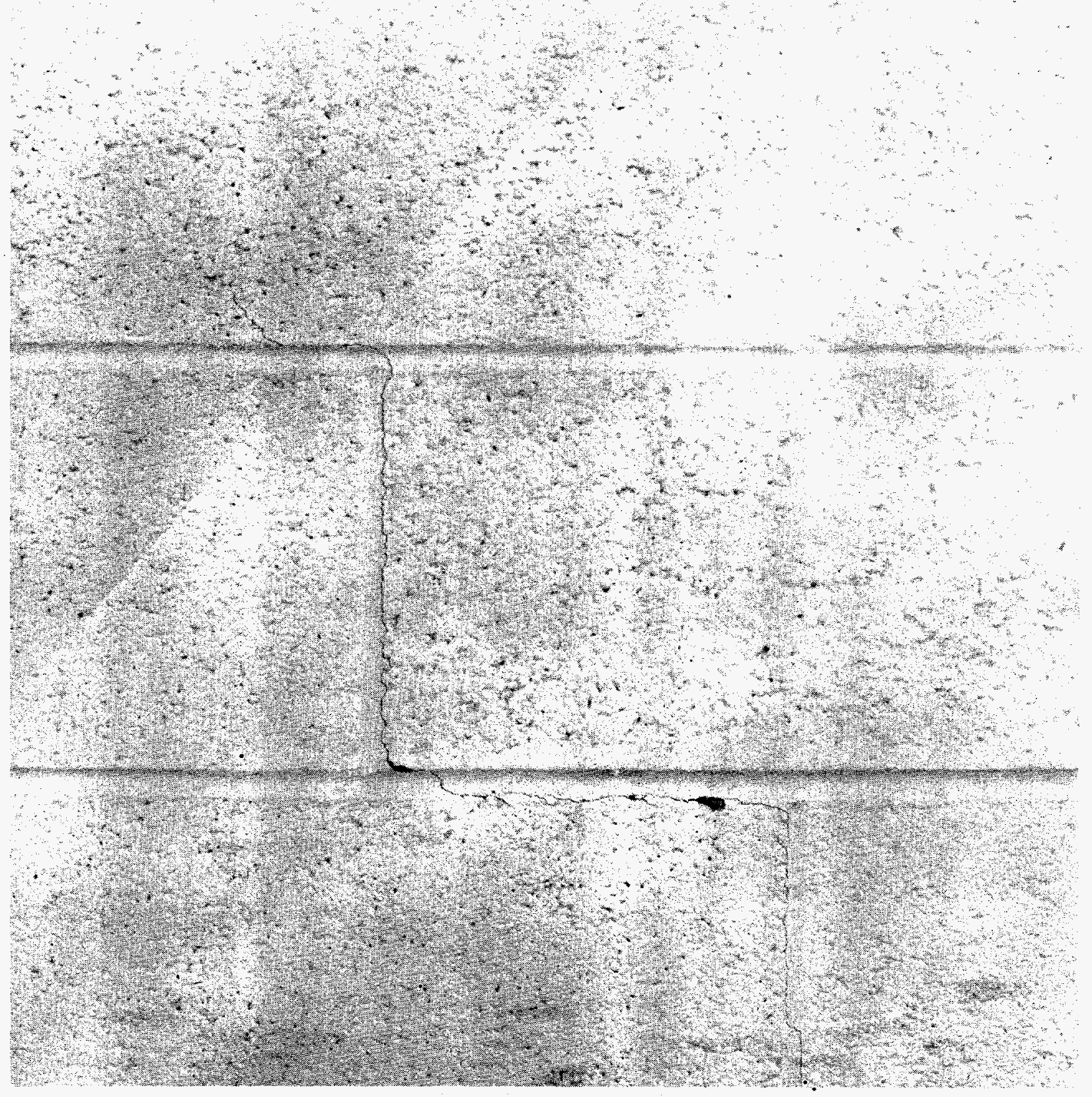

Fig. B-8. Building 752, north end (fresh flakes were found on ground) $0.18 \mathrm{~cm} / \mathrm{sec}$. 


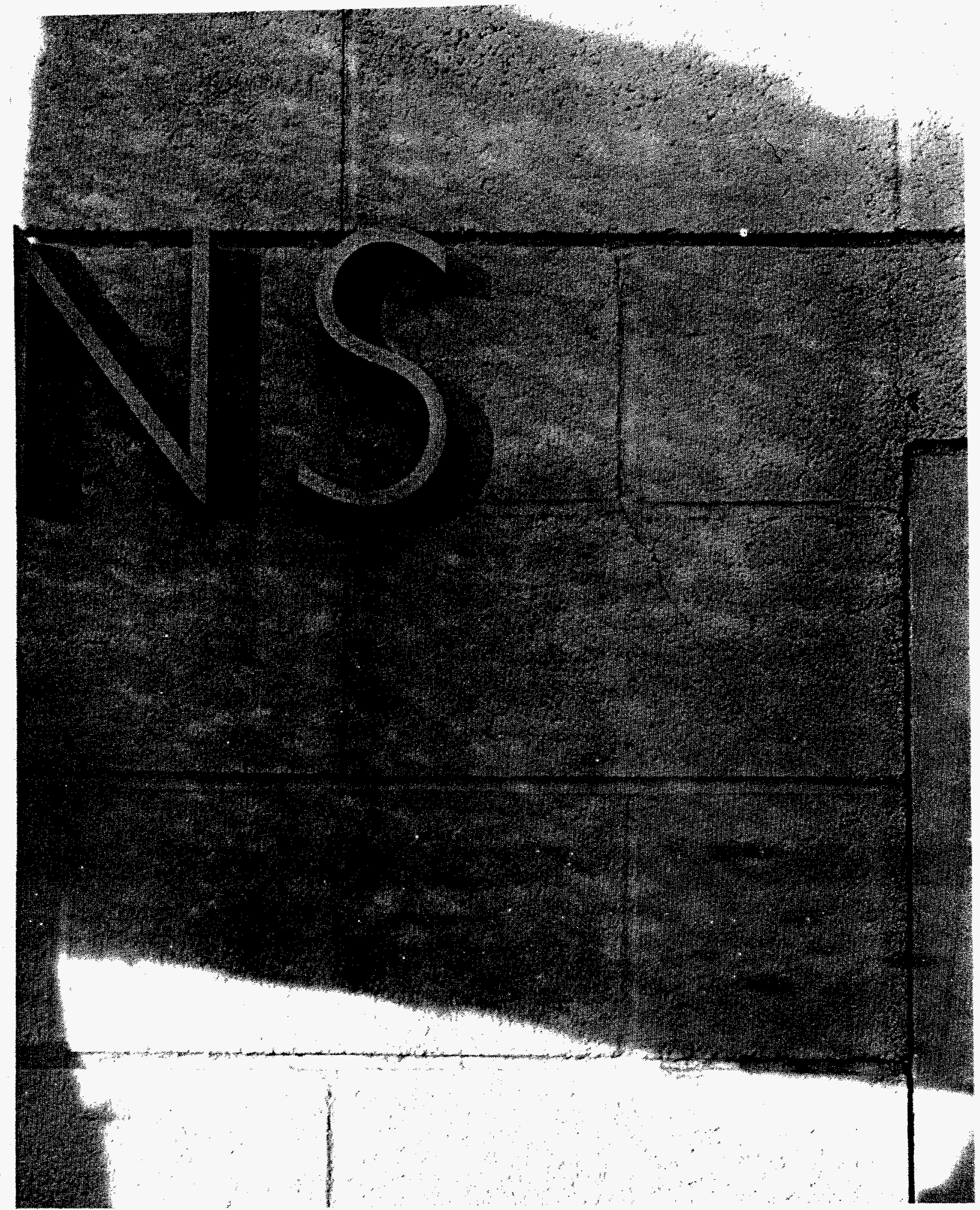

Fig. B-9. Building 726, 40-in. crack above " $S$ " present on 1 and 7 Dec.; 16-in. extension of crack through " $S$ " and a new 19-in. crack to the right present on 16 Dec., $0.21 \mathrm{~cm} / \mathrm{sec}$. 


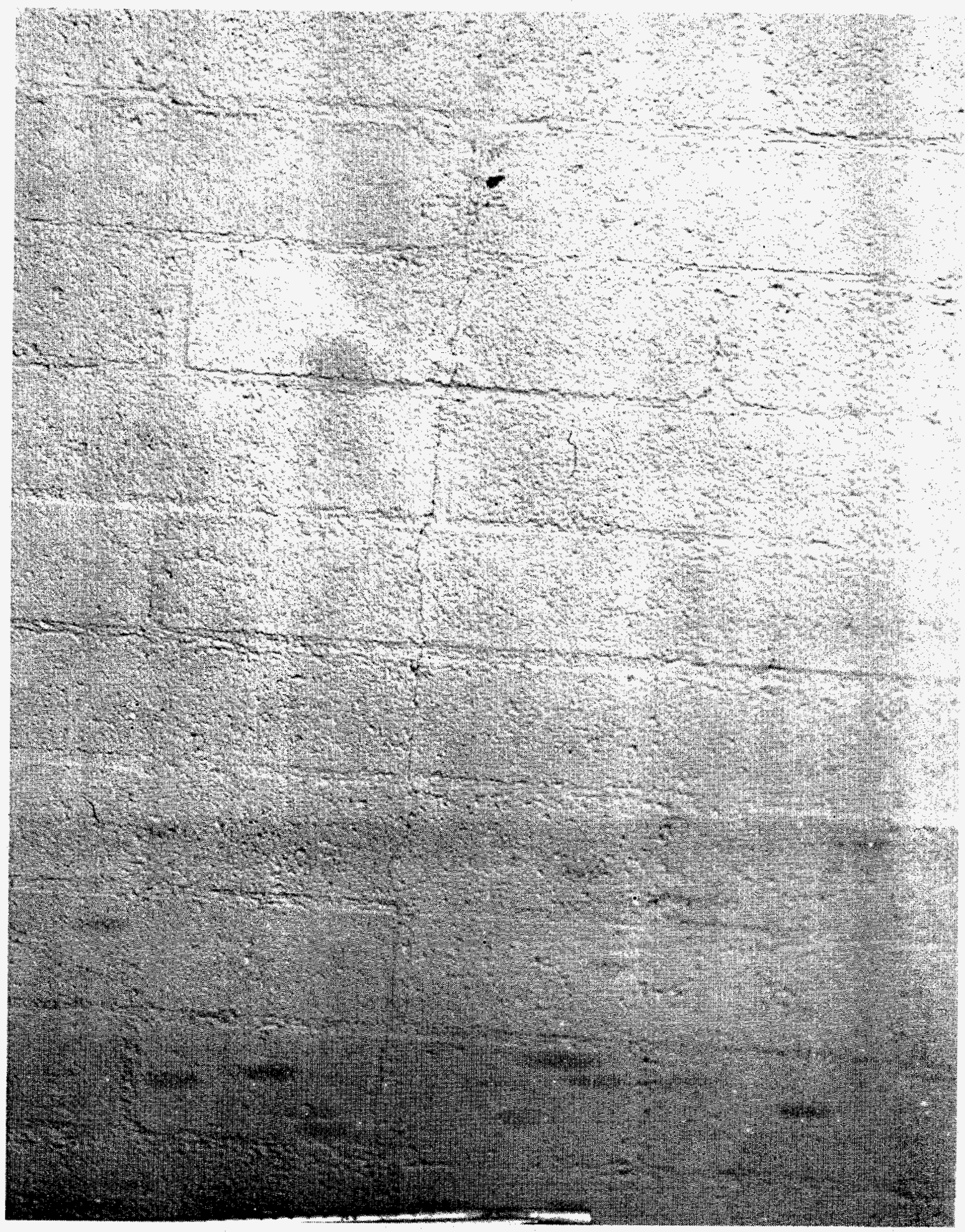

Fig. B-10. Building 155, east side, $0.21 \mathrm{~cm} / \mathrm{sec}$. 


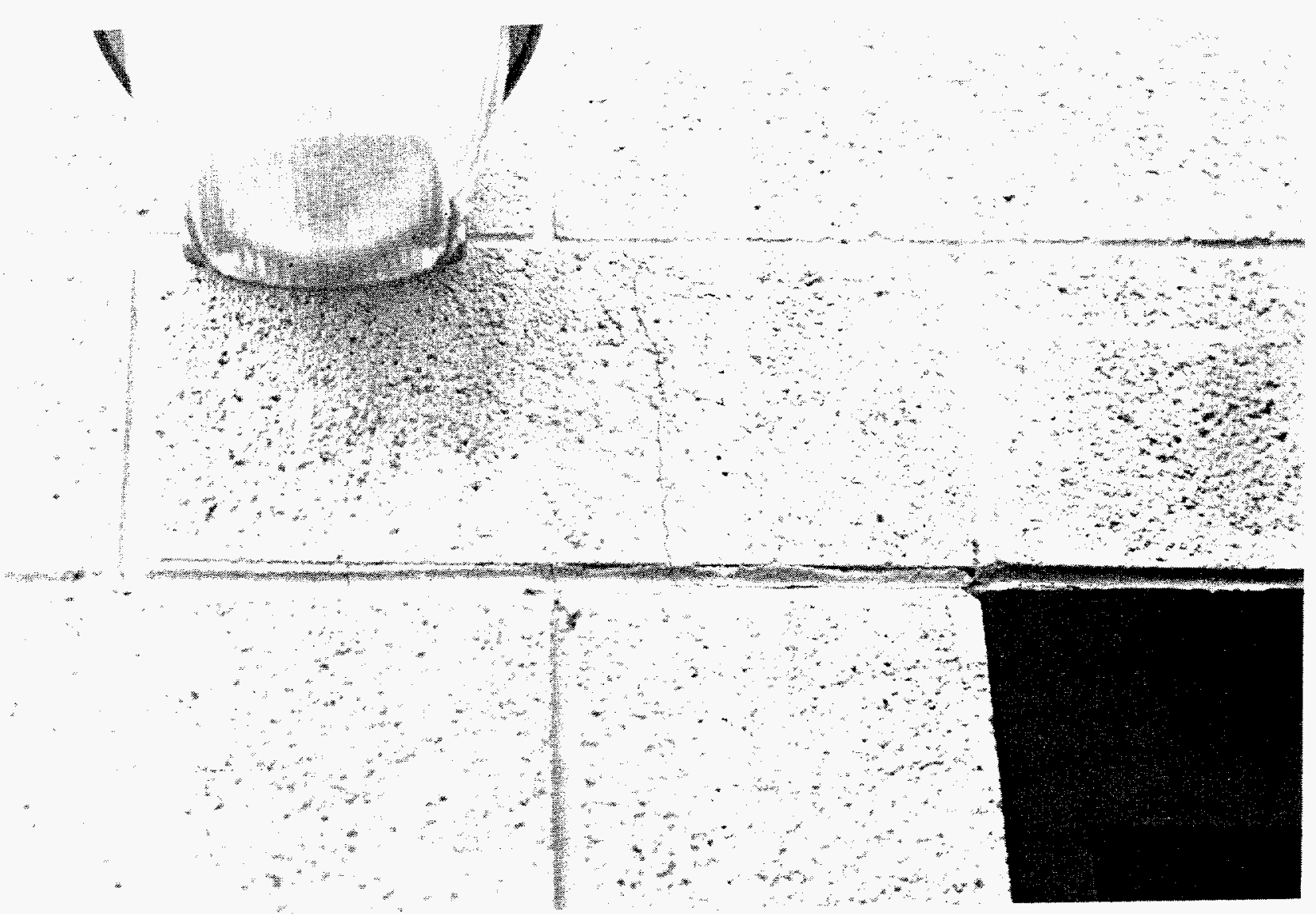

Fig. B-11. Building 1002, horizontal hairline over south door present on 1 and 7 Dec.; 16 -in. vertical extension of crack present on 16 Dec., $0.21 \mathrm{~cm} / \mathrm{sec}$.

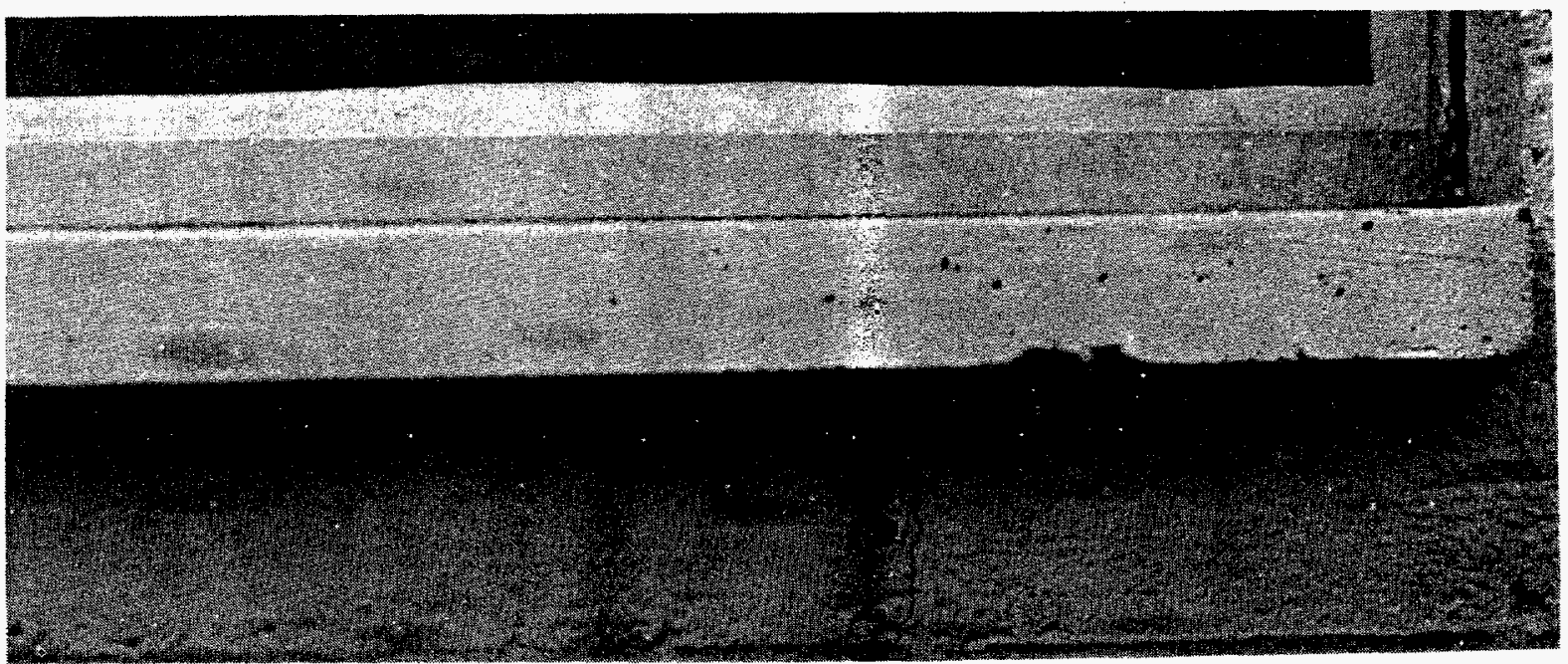

Fig. B-12: Building 700, vertical hairline under front window ledge, 0.21 $\mathrm{cm} / \mathrm{sec}$. 


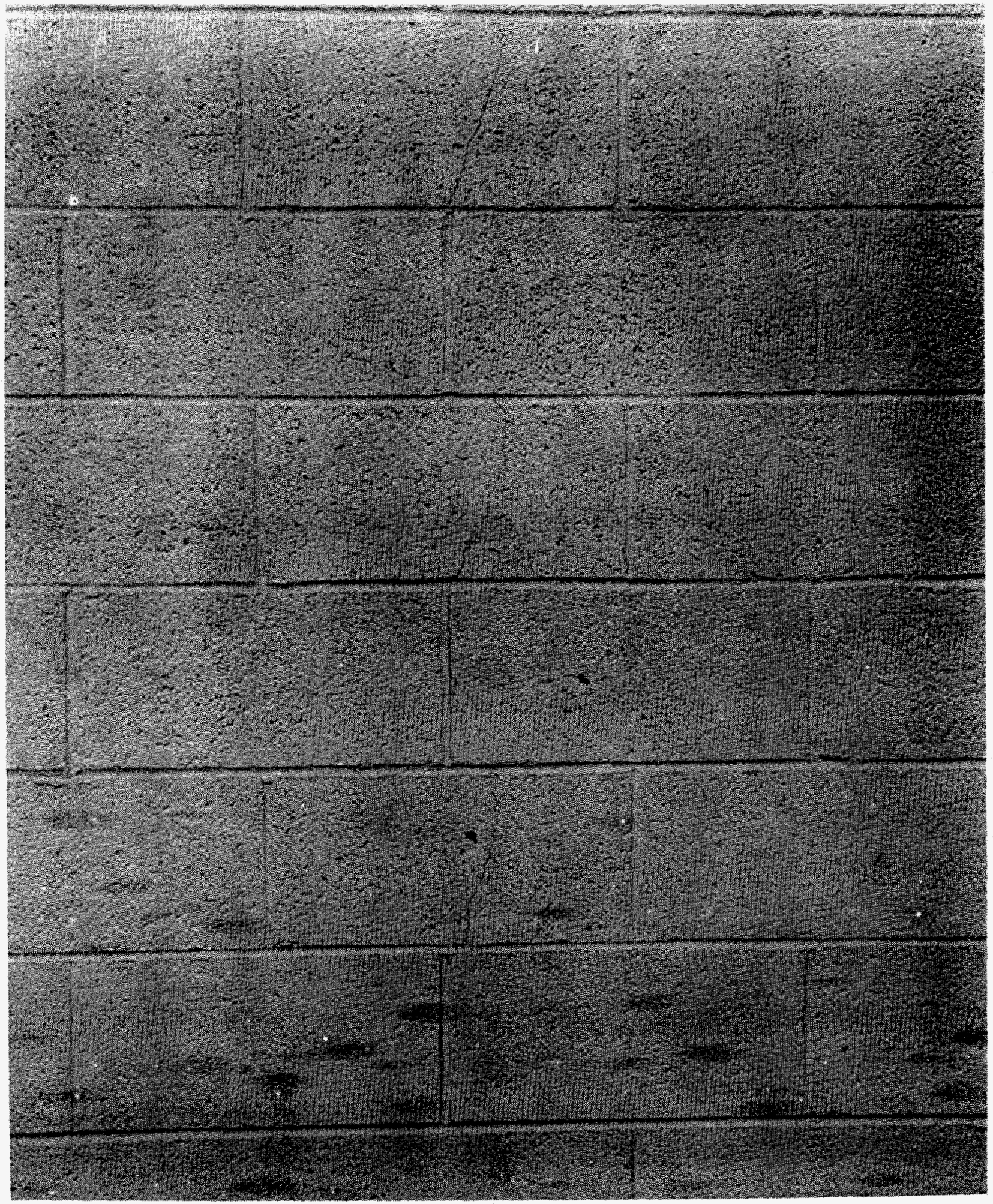

Fig. B-13. Building.700, south wall, $0.21 \mathrm{~cm} / \mathrm{sec}$. 


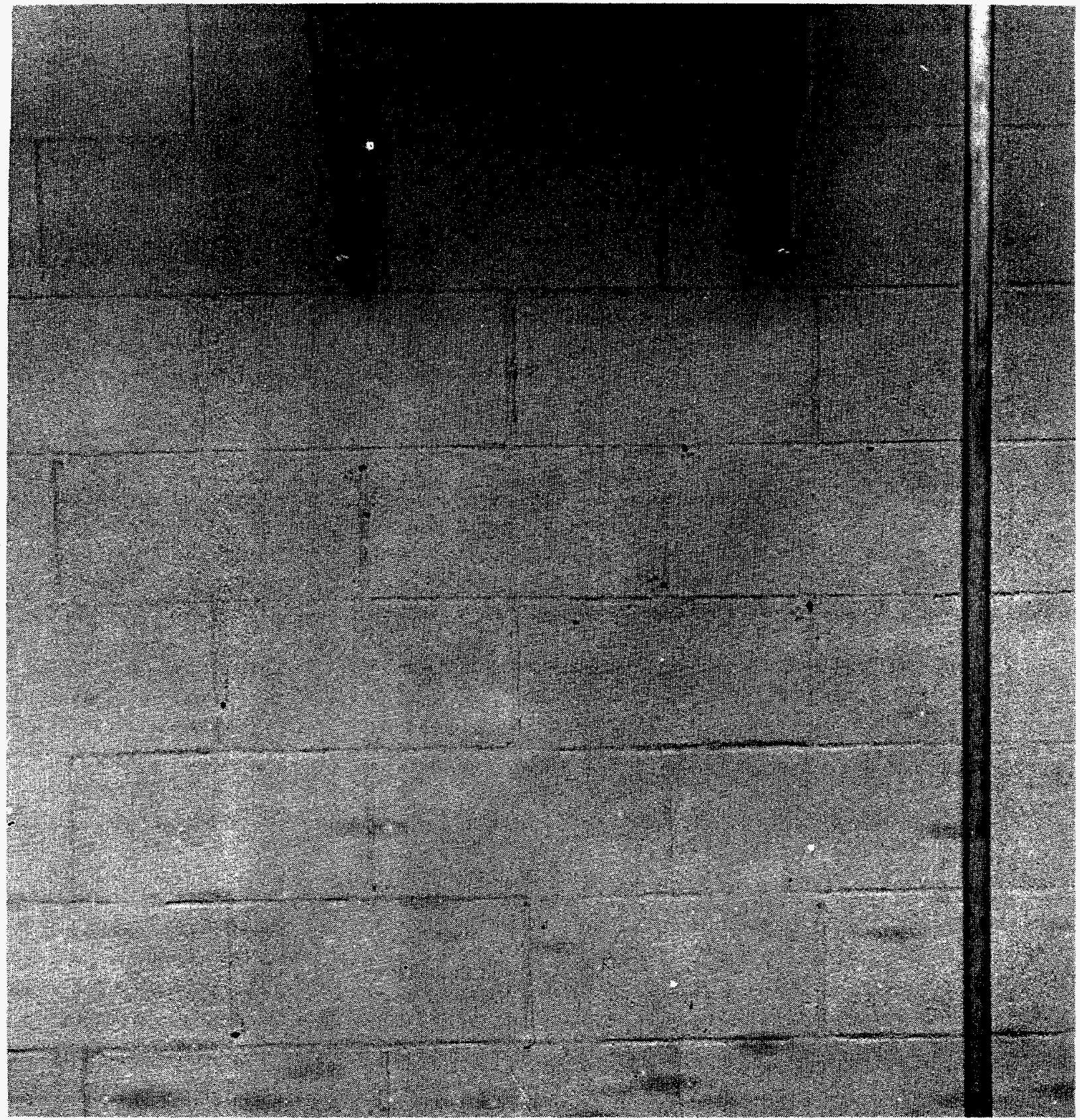

Fig. B-14. Building 479, extensive cracking under air conditioner, $0.21 \mathrm{~cm} / \mathrm{sec}$. 


\section{$-65-$}

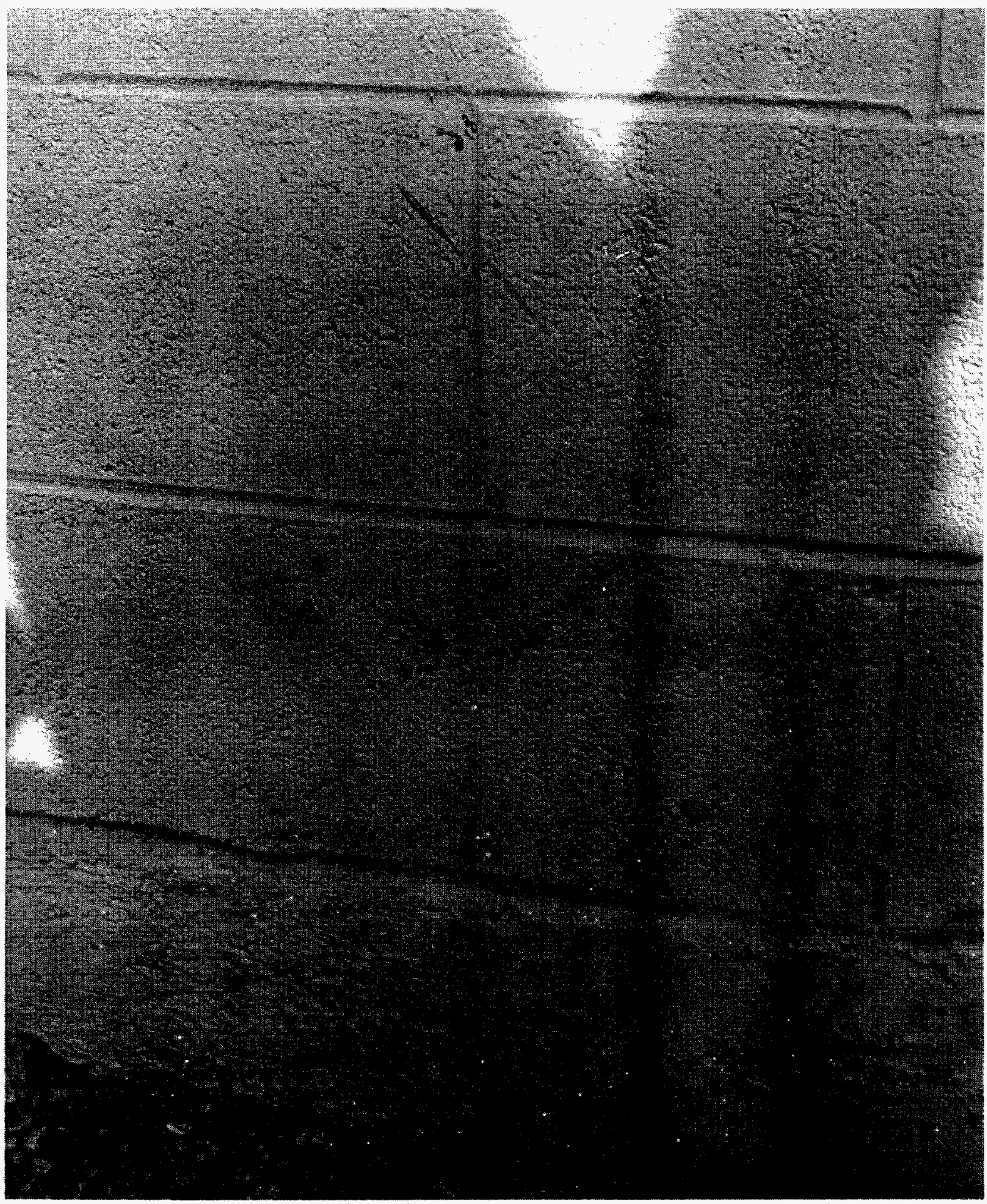

Fig. B-15. Building 710, south side, $0.13 \mathrm{~cm} / \mathrm{sec}$. 


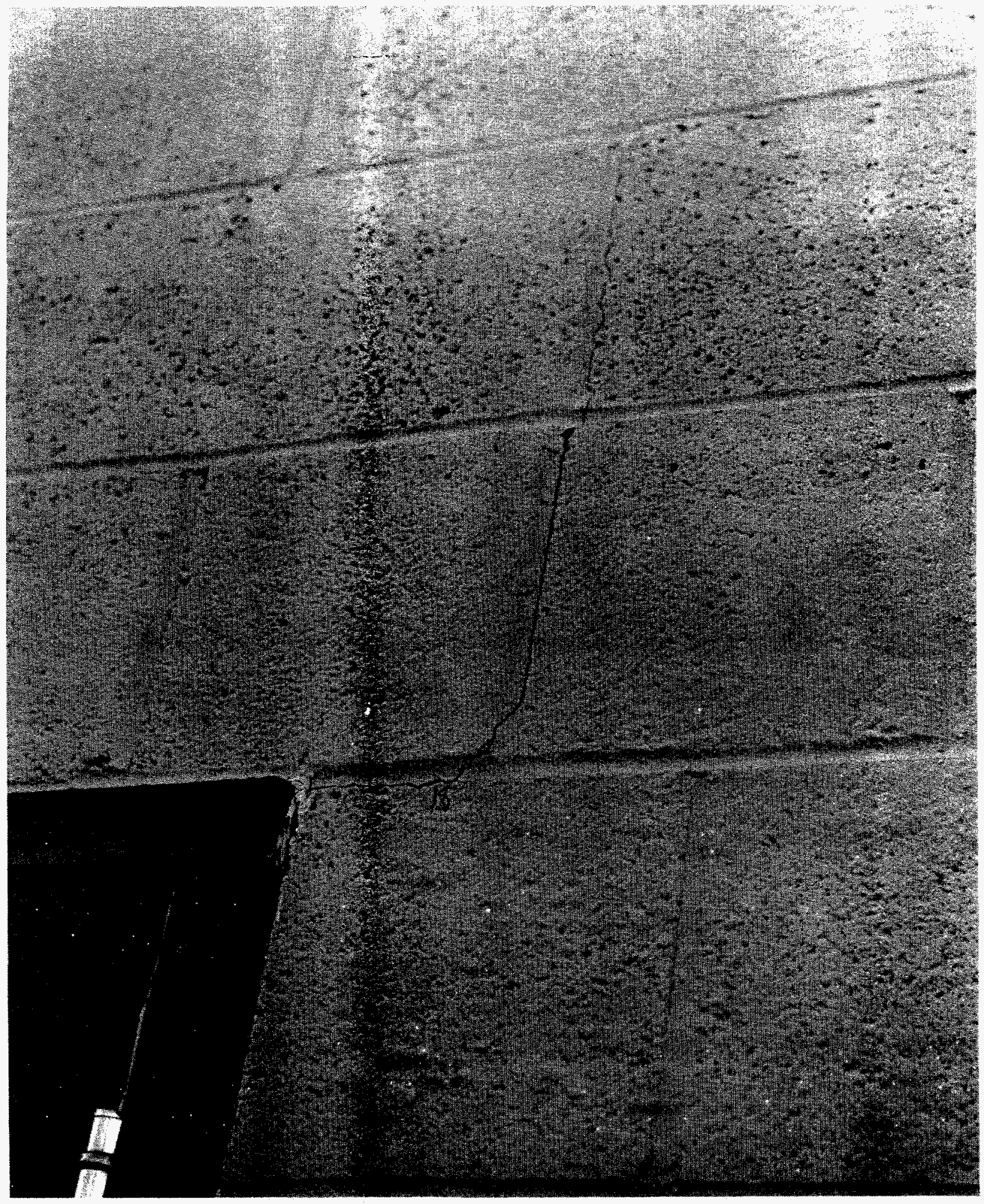

Fig. B-16. Building 701, north end of east side, crack over fan room door, $0.13 \mathrm{~cm} / \mathrm{sec}$. 


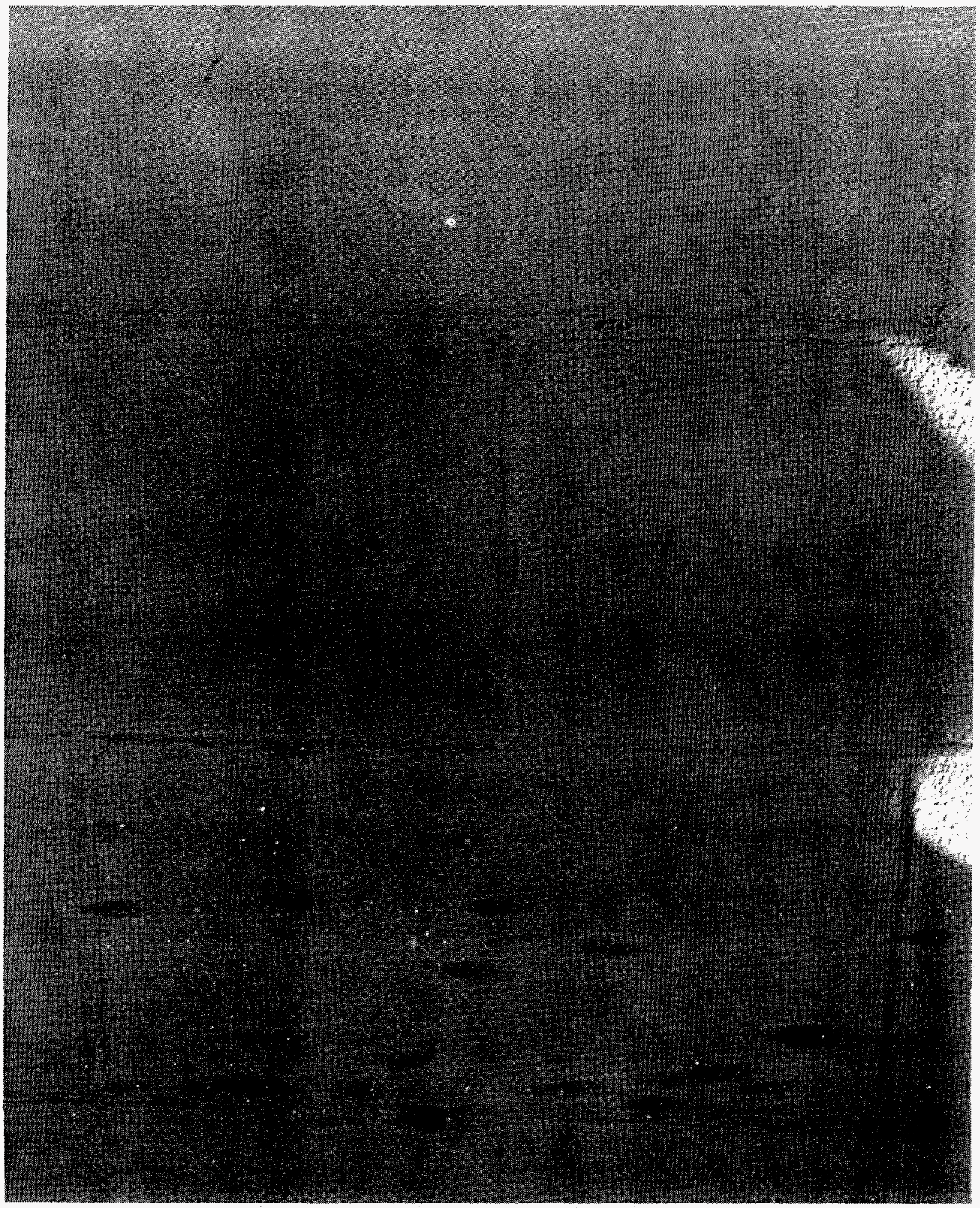

Fig. B-17. Building 479, 80-in. hairline crack at northeast corner, $0.13 \mathrm{~cm} / \mathrm{sec}$. 


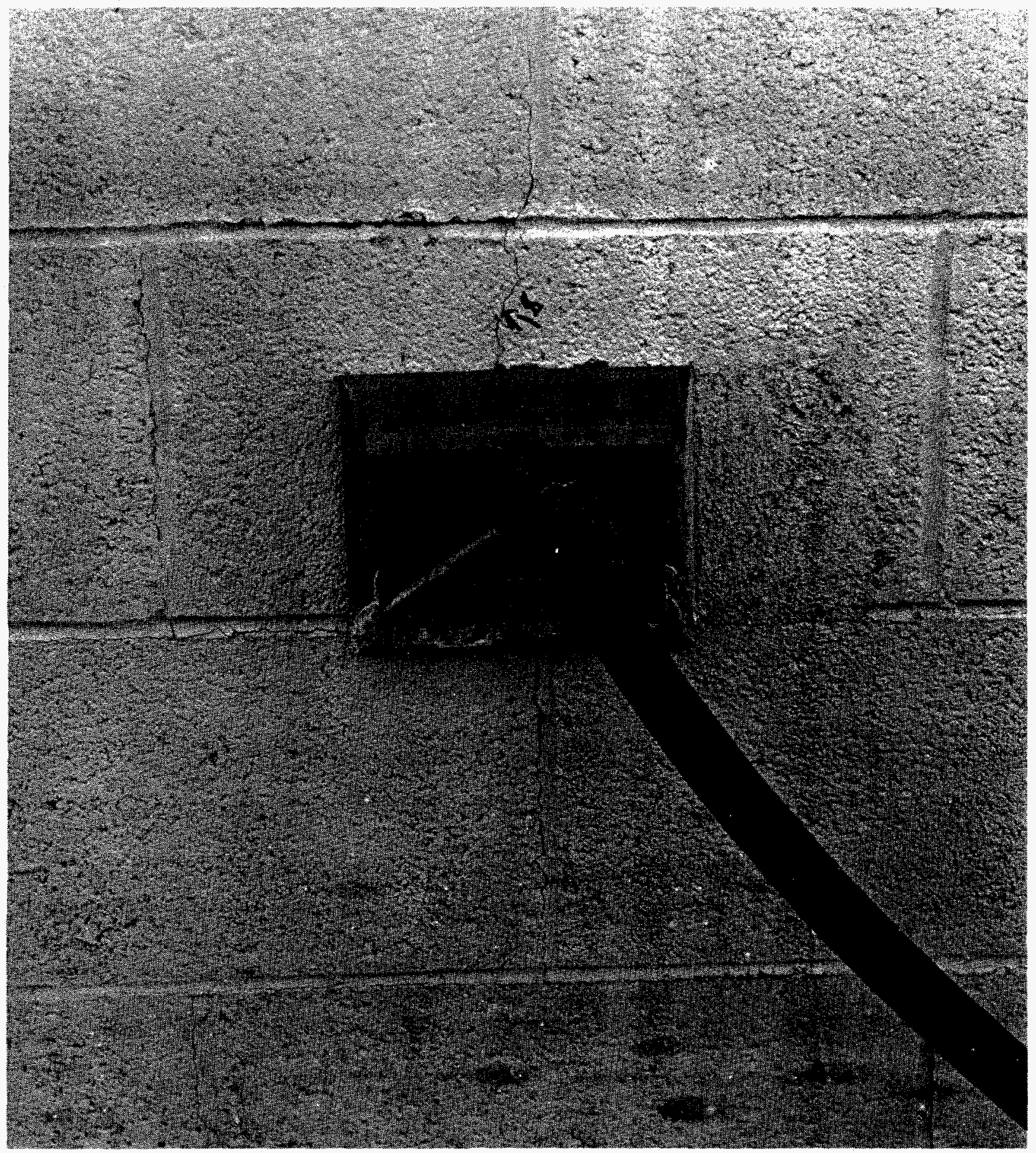

Fig. B-18. Building 790, west side, $0.13 \mathrm{~cm} / \mathrm{sec}$. 


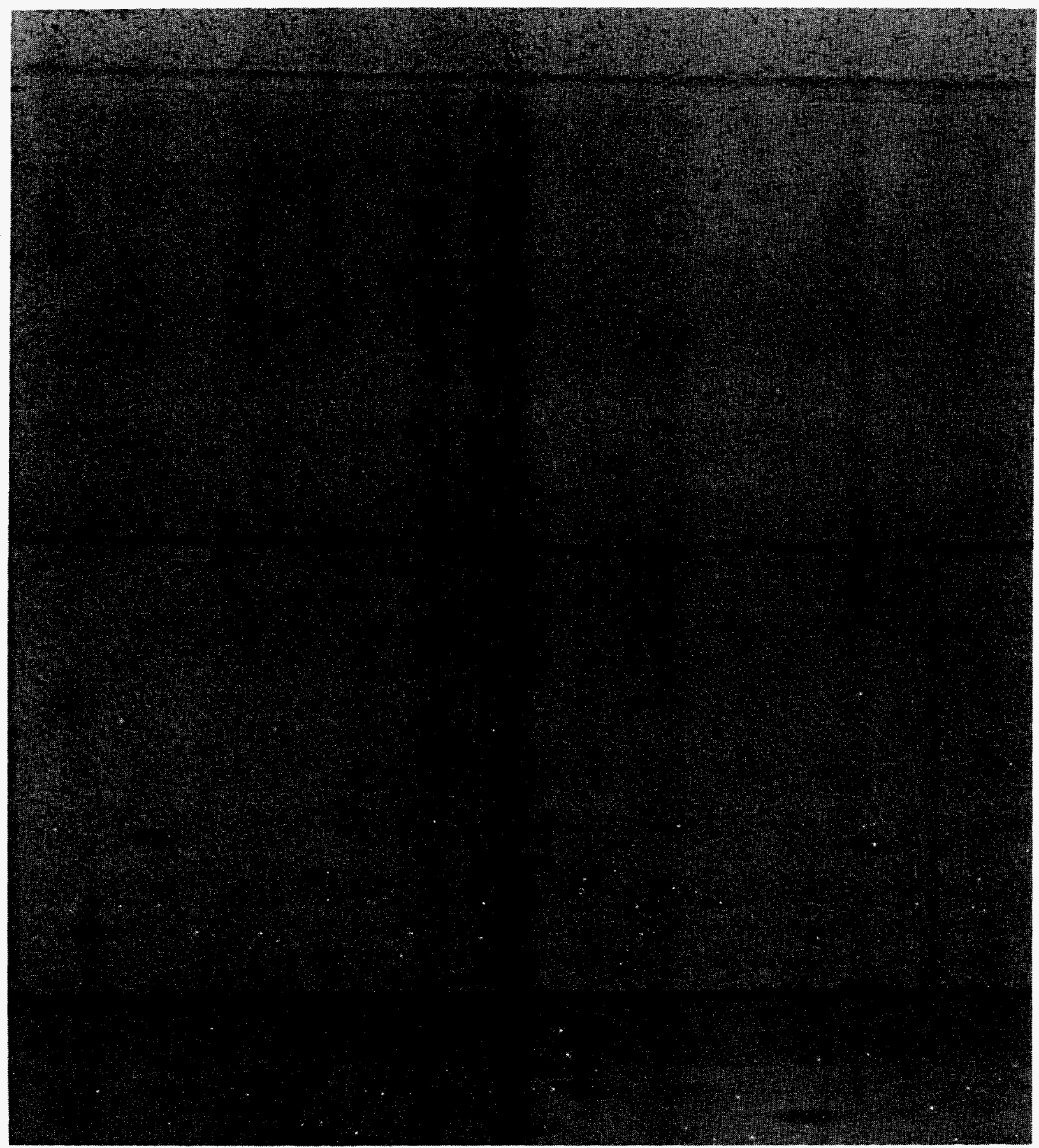

Fig. B-19. Building 684, northwest end, flaking along old hairline, $0.13 \mathrm{~cm} / \mathrm{sec}$. 


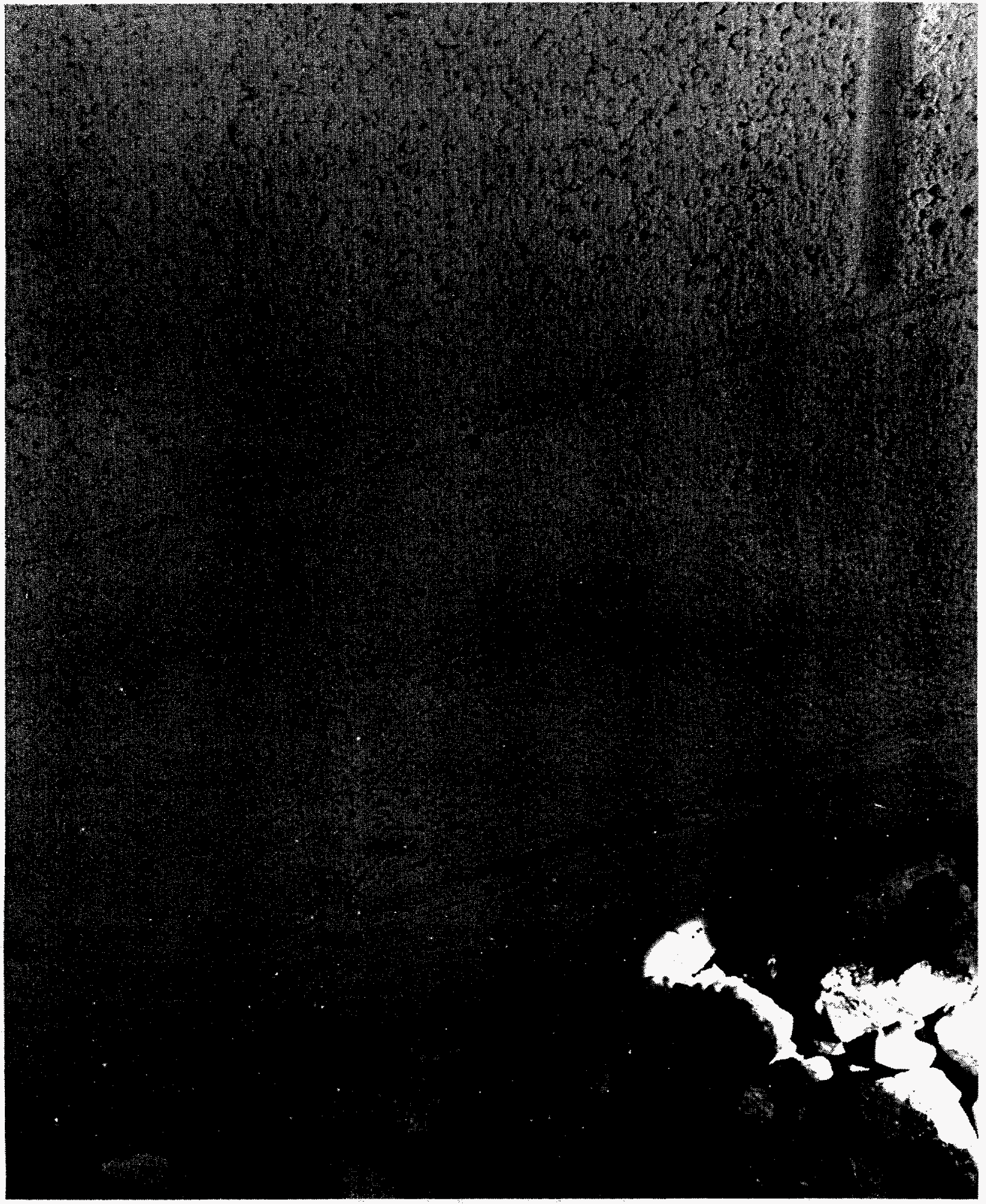

Fig. B-20. Building 676, step crack with some flaking, intermediate inspection. 


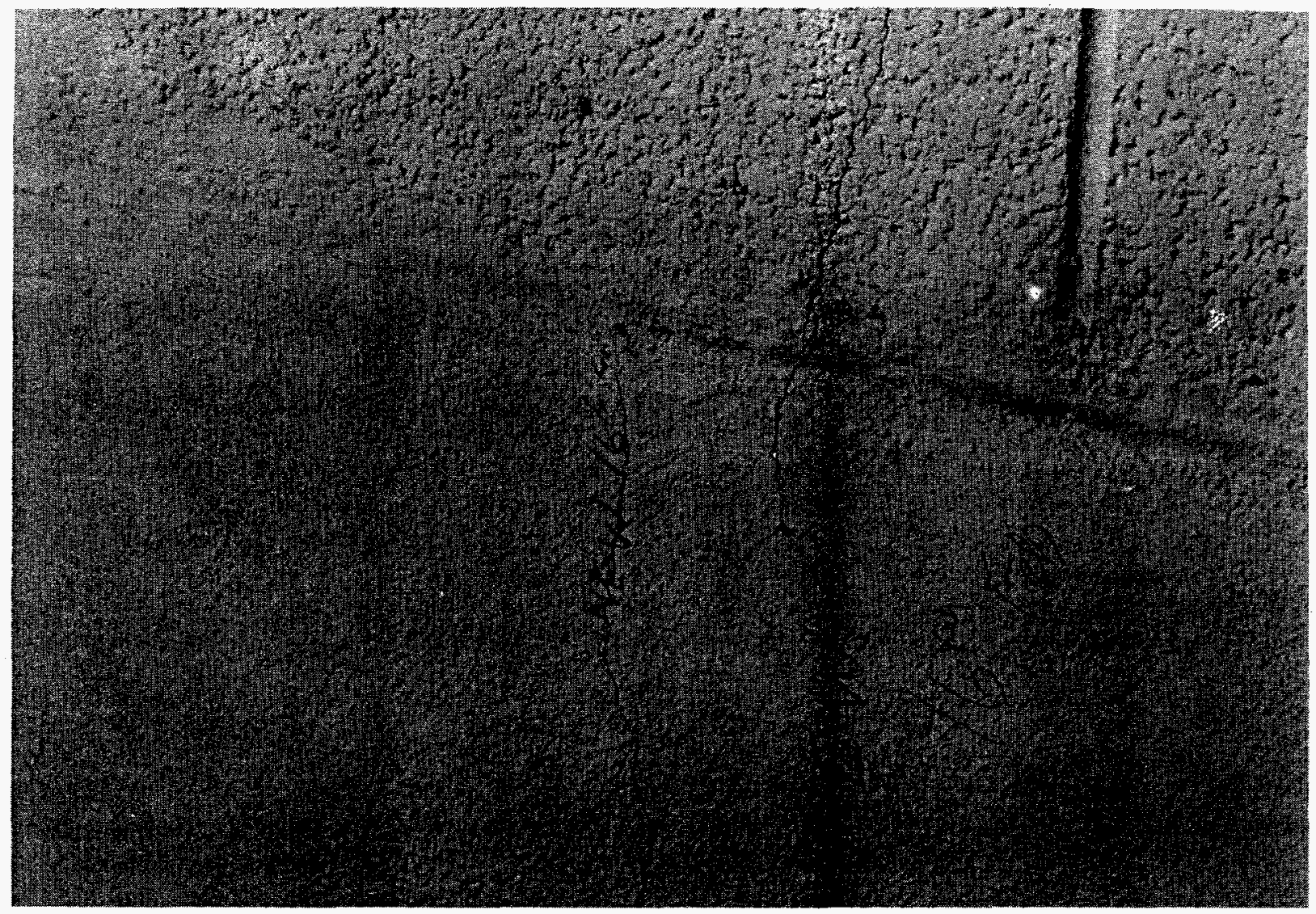

Fig. B-21. Building 1000, east side, intermediate inspection.

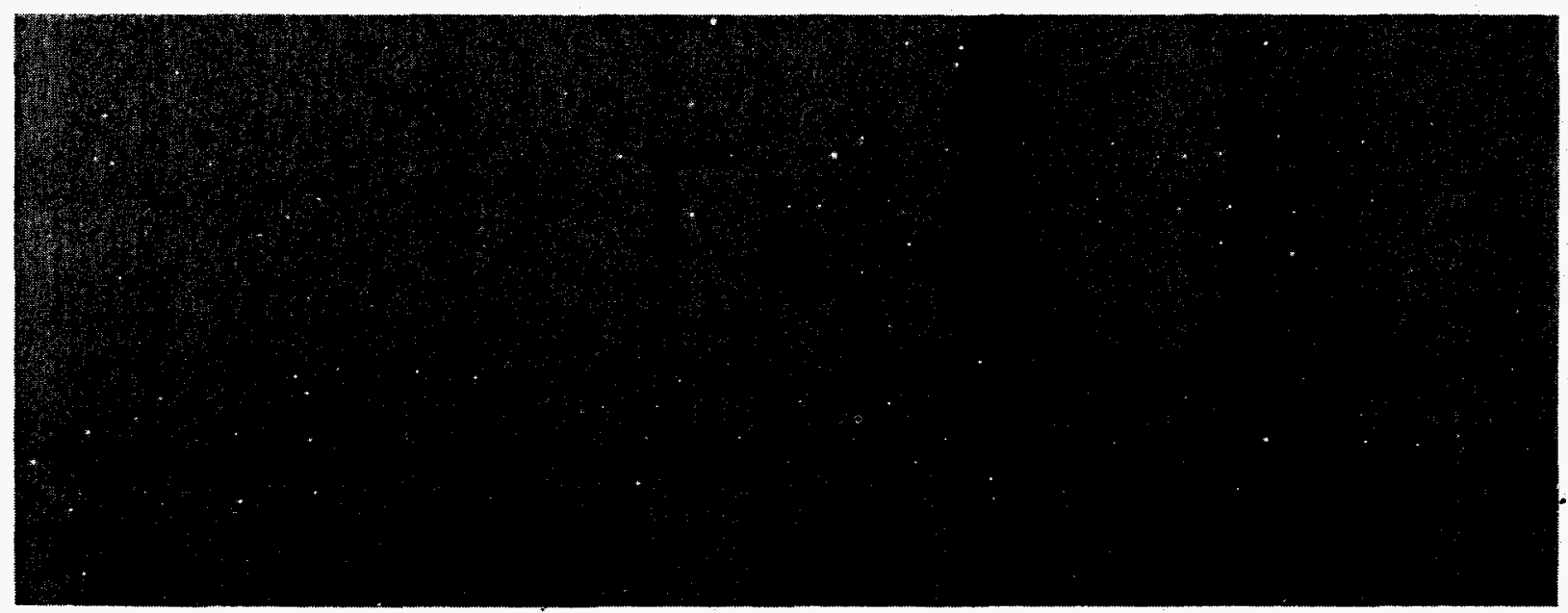

Fig. B-22. Building 679, several new flakes along old, low horizontal crack, intermediate inspection. 


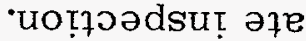

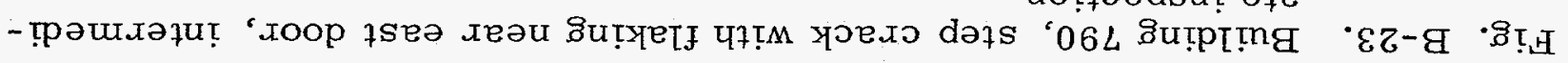

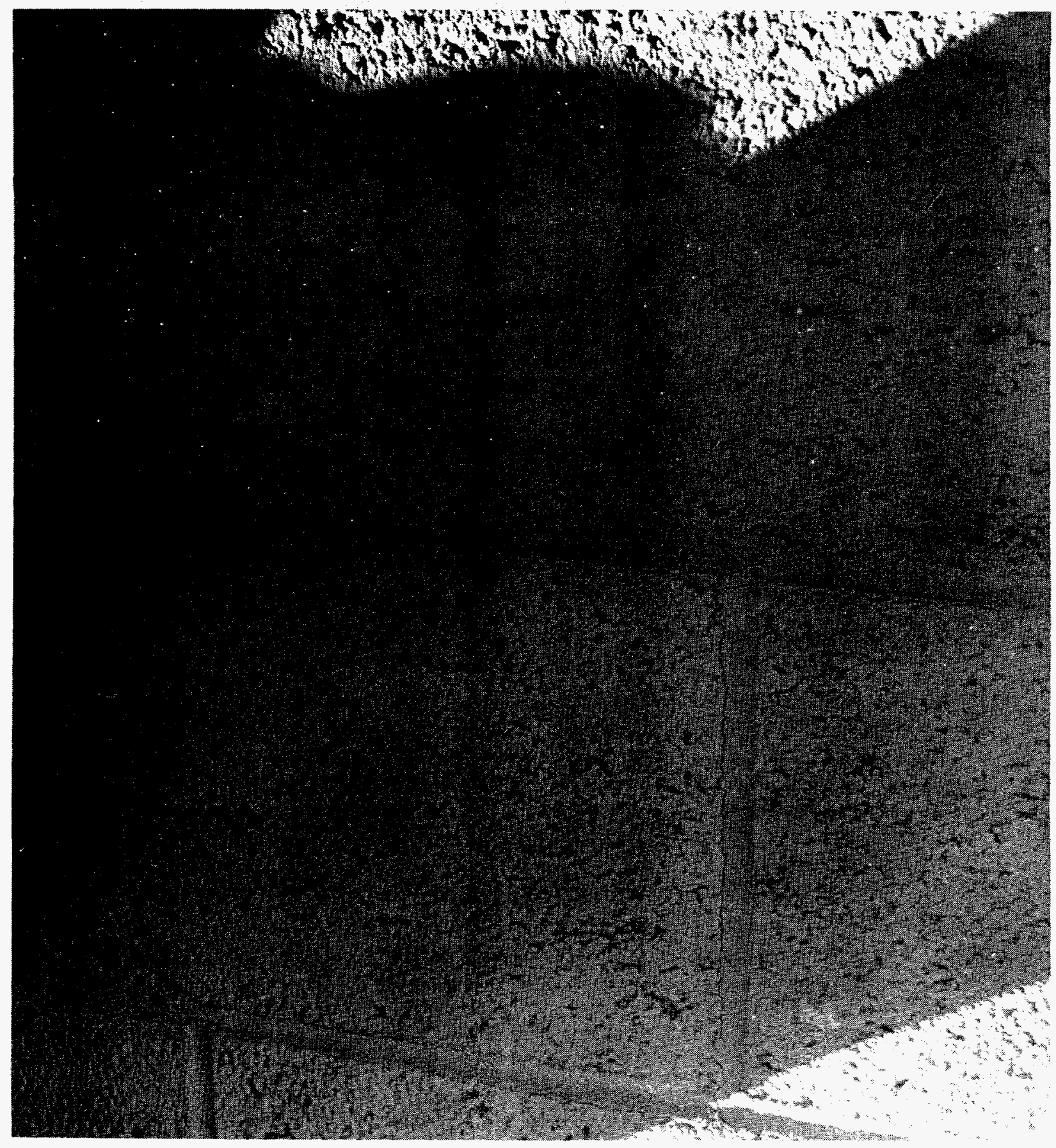




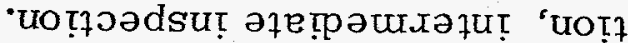

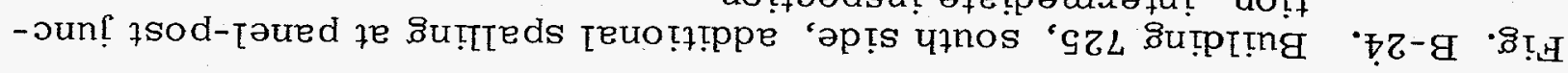
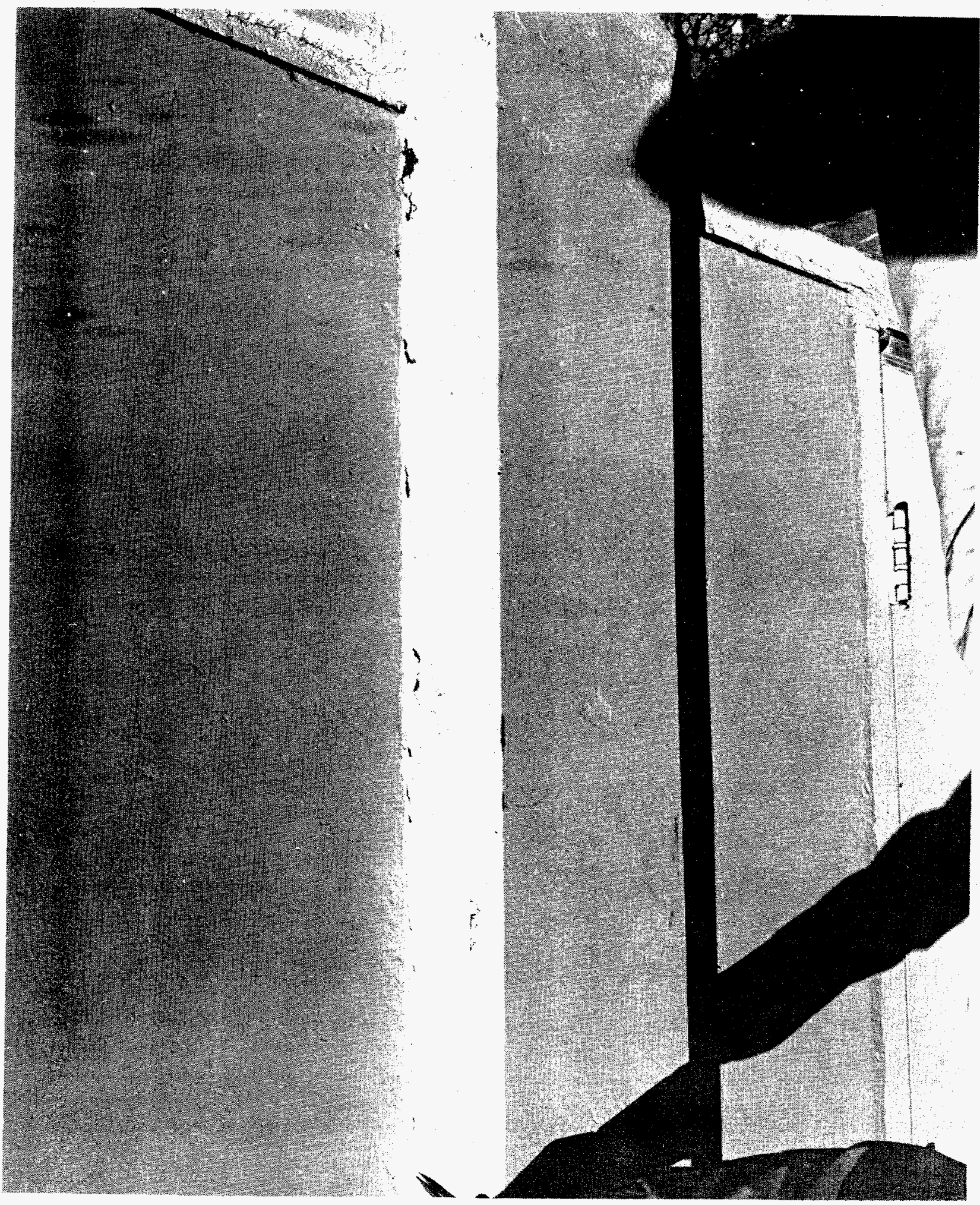


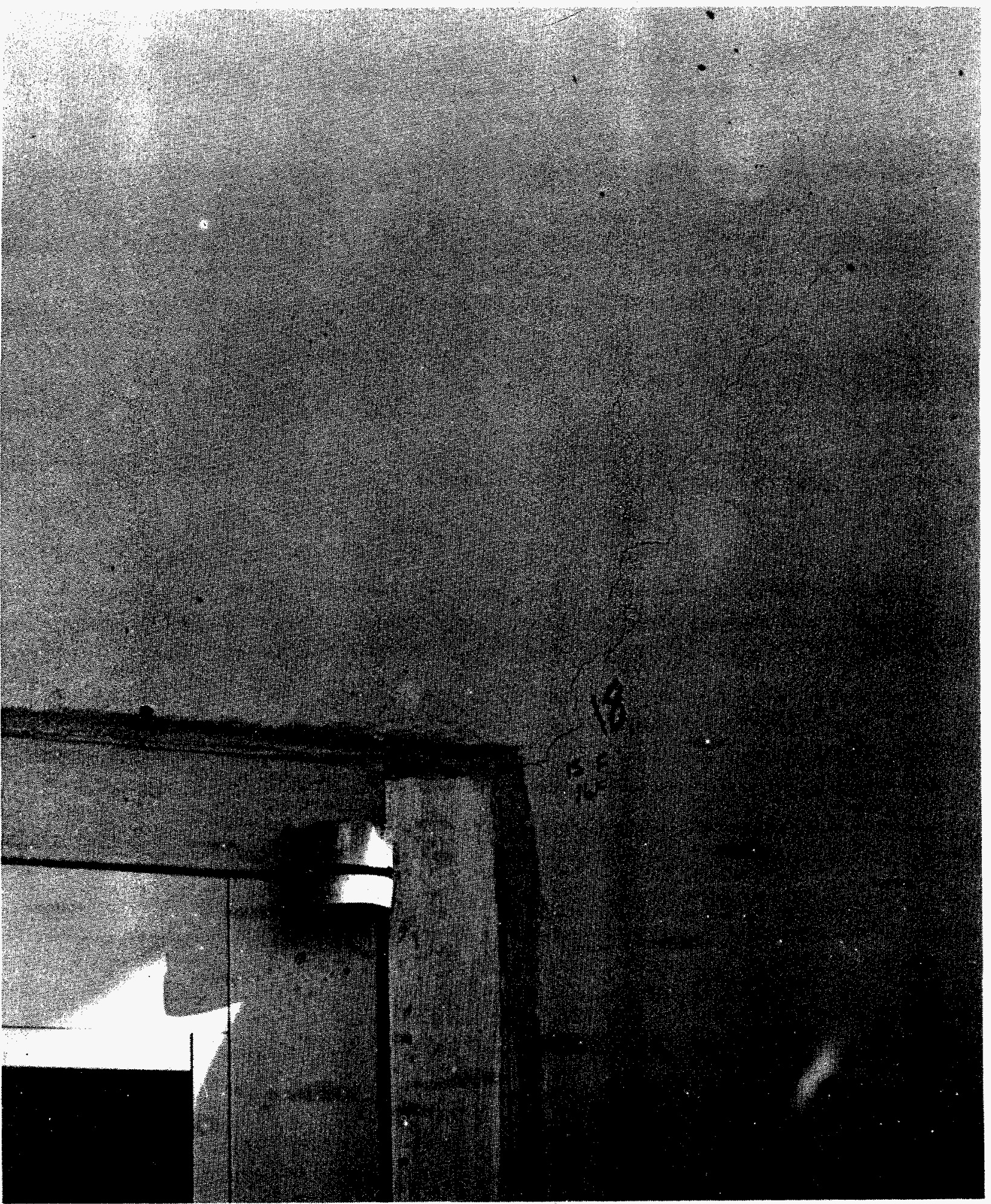

Fig. B-25. Building 725, minute diagonal crack over main door, intermediate inspection. 


\section{APPENDIX C}

PROXIMITY GAGES

Daily logs were kept of high and low temperatures at Mercury and maximum wind gusts at Yucca weather station (Fig. C-1). The expansion and contraction associated with the daily Mercury temperature extremes are capable of causing large movements in existing cracks. A temperature sensing unit, Fig. C-2, installed within the south, sunny, wall of Building 481 indicated about a $43^{\circ} \mathrm{C}$ daily difference between high and low wall temperatures during the period 16-19 Jan. 1966 (Fig. C-3). A hydrograph, in a shaded location by Building 480 , indicated air temperature differences of $12^{\circ} \mathrm{F}$. Figure C-4 gives temperature and humidity data of the hydrograph for 17-19 Jan. 1966.

In order to record temperature and seismic induced movements, Bentley proximity gages with Sanborn and Massa-Cohu recorders were mounted across six existing cracks at five locations during a 24-hour background test and during a nuclear event 18 Jan. 1966. Ordinary thermometers were placed at each detecting unit. Typical installations are found in Figs. C-5, C-6, and C-7.

One crack was instrumented by Bentley gages and strain gages subsequent to 19 Jan. 1966. Bakelite-mounted detectors using a dual-channel Sanborn recorder were installed on both sides of this crack on the exterior and interior wall of the west end of Building 681. Gages were not opposite each other. Daily crack movements were large. Figures C- 8 and C-9 present data taken on the outside and inside of an existing crack in the west wall of Building 681. Background instrumentation on $18 \mathrm{Jan}$. indicated crack width differences of 3.9 and 4.6 mils on the inside and outside, respectively. Measurements of $20 \mathrm{Apr}$. showed differences of 4.0 and 8.3 mils, respectively.

The same instrumentation was employed during nuclear detonations on $18 \mathrm{Jan} .1966$ and $25 \mathrm{Apr}$. 1966; resultant peak particle velocities at Building 681 were approximately 0.14 and $0.32 \mathrm{~cm} / \mathrm{sec}$, respectively. Crack movements were negligible during both events. Crack movements could be inferred by using an etched scale magnifier and reading amplitudes to the nearest $0.1 \mathrm{~mm}$. Arrival times ascertained by this method appeared reasonable for distance and geology to the detonation. 

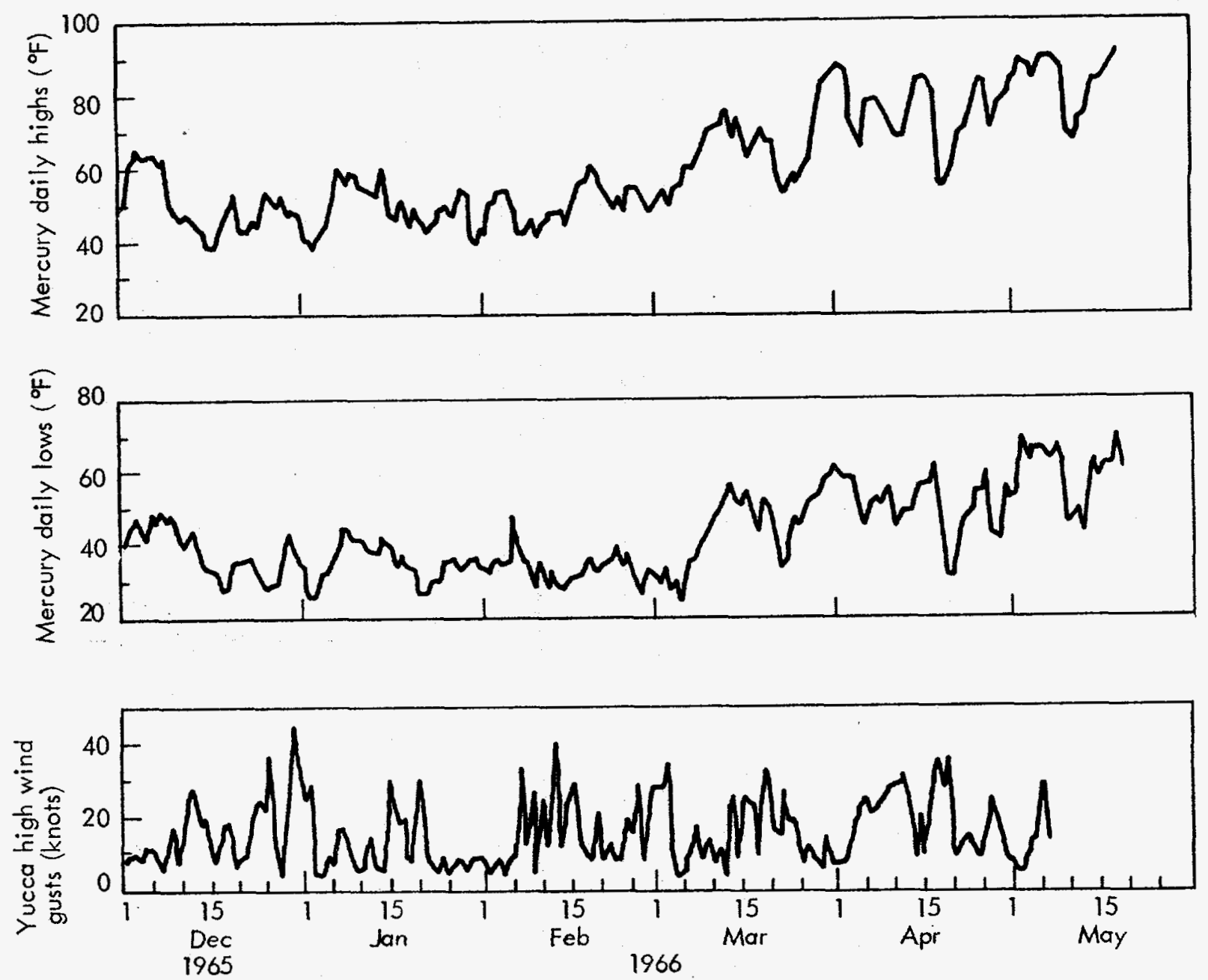

Fig. C-1. Daily high and low temperatures at Mercury and maximum wind gusts at the Yucca weather station. 


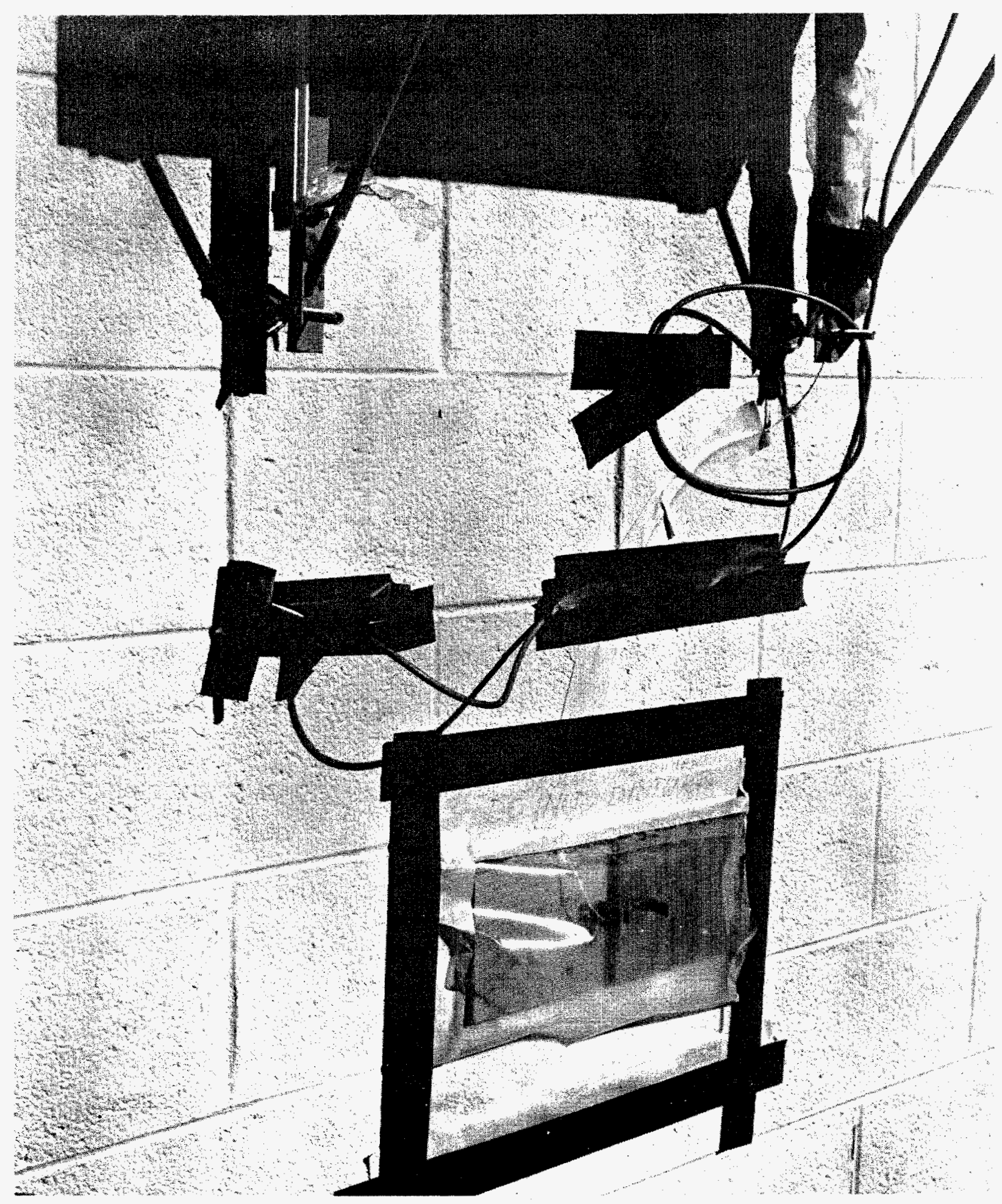

Fig. C-2. Covered Bentley detector and wall temperature sensing unit, south wall of Building 481. 


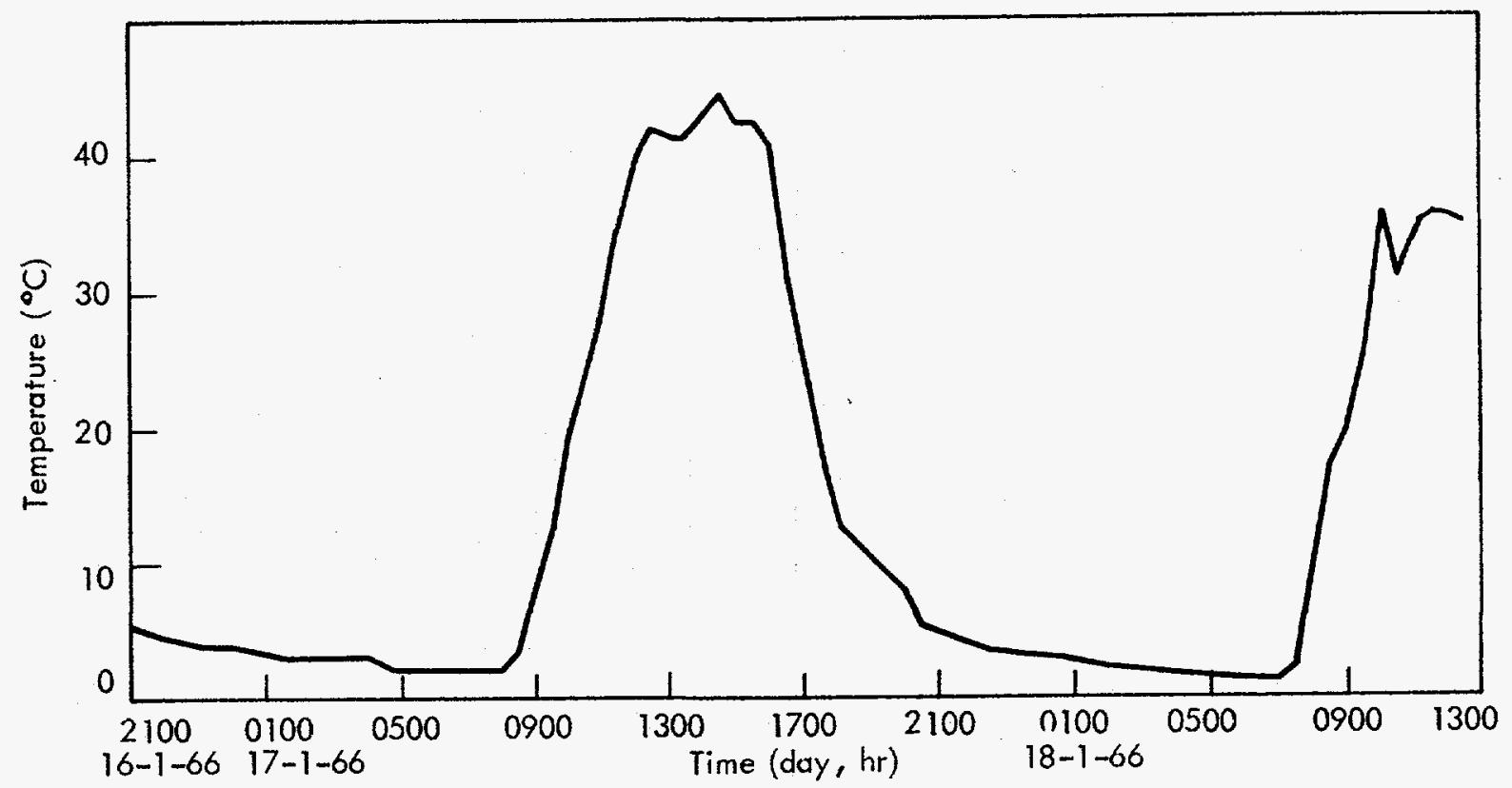

Fig. C-3. Sample temperatures as measured with the wall temperature sensing unit installed in south wall of Building 481 .
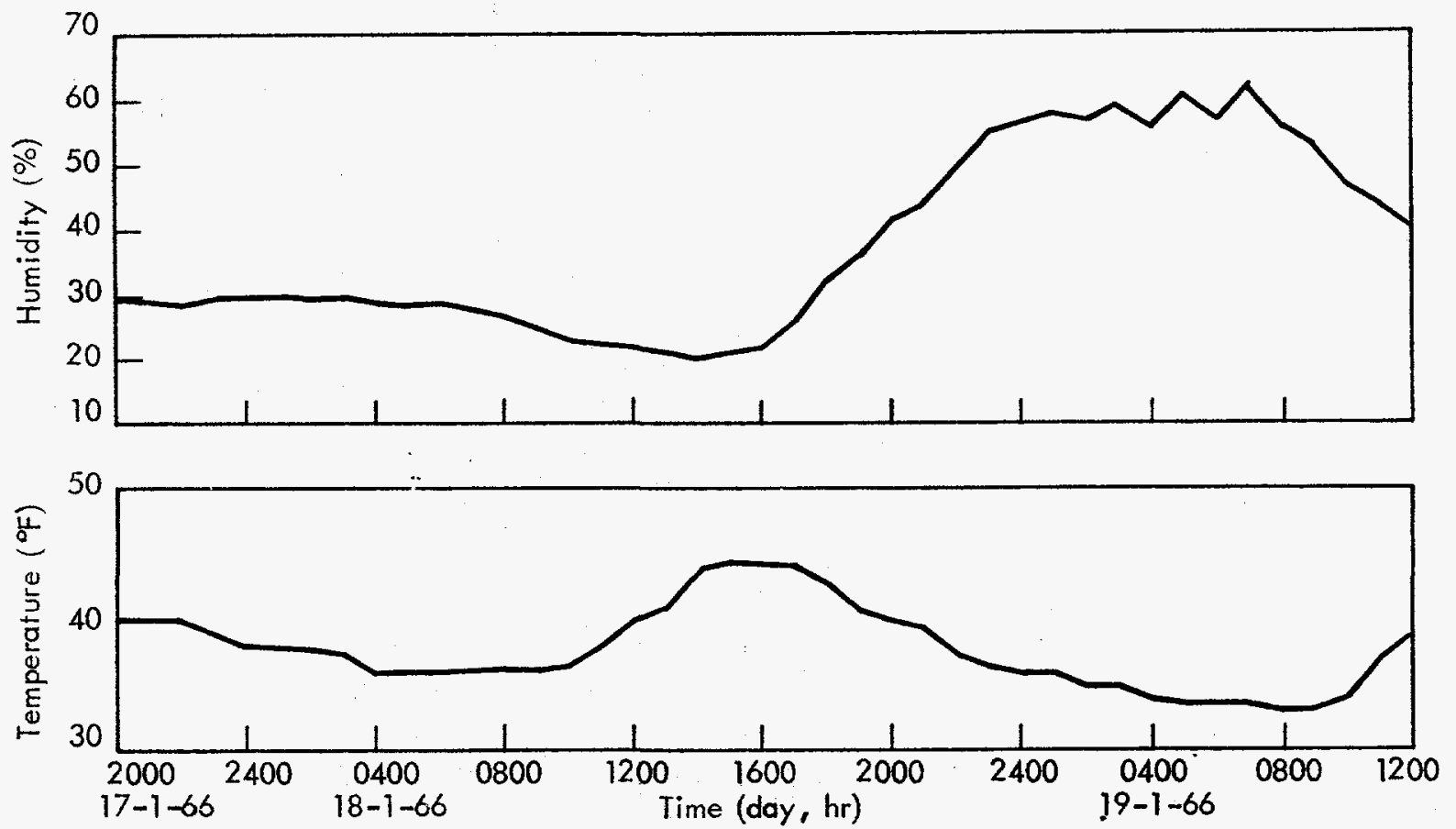

Fig. C-4. Temperature and humidity data as measured with a hydrograph outside Building 480 . 


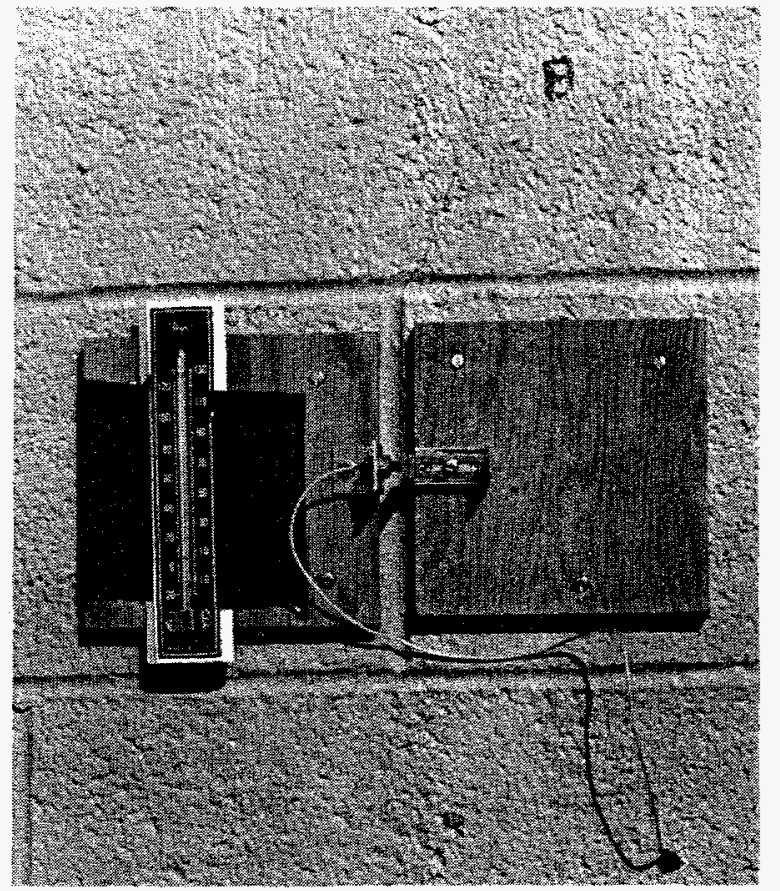

Fig. C-5. Bentley detector, south end of Building 700 .

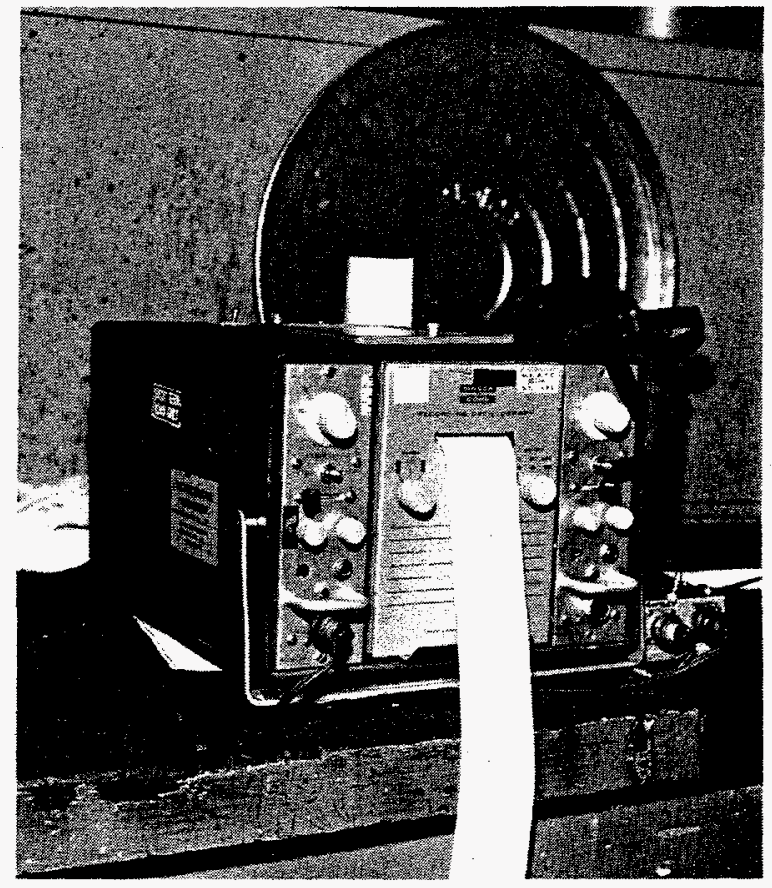

Fig. C-6. Massa-Cohu recorder, Building 700 .

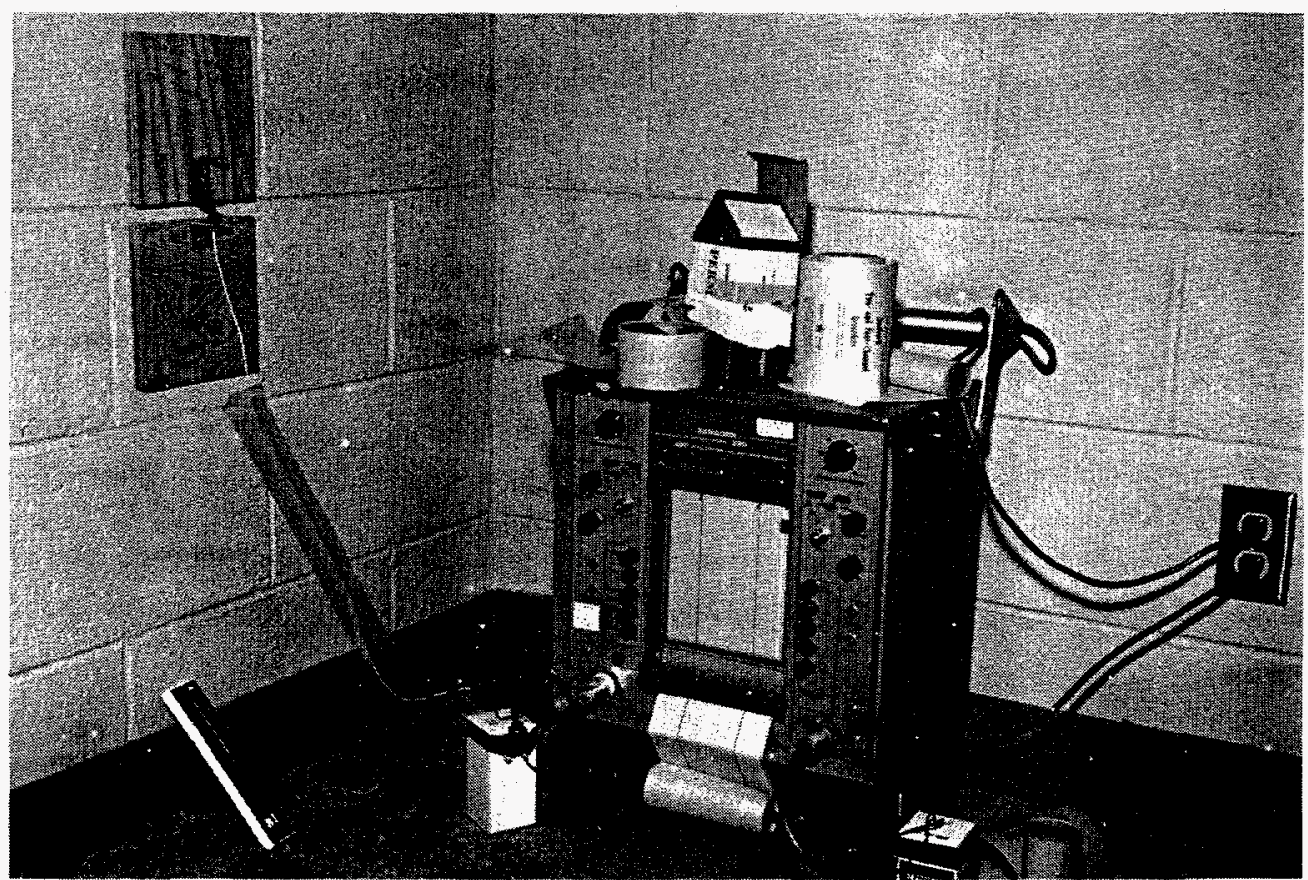

Fig. C-7. Bentley detector and Sanborn recorder inside Building 681 . 


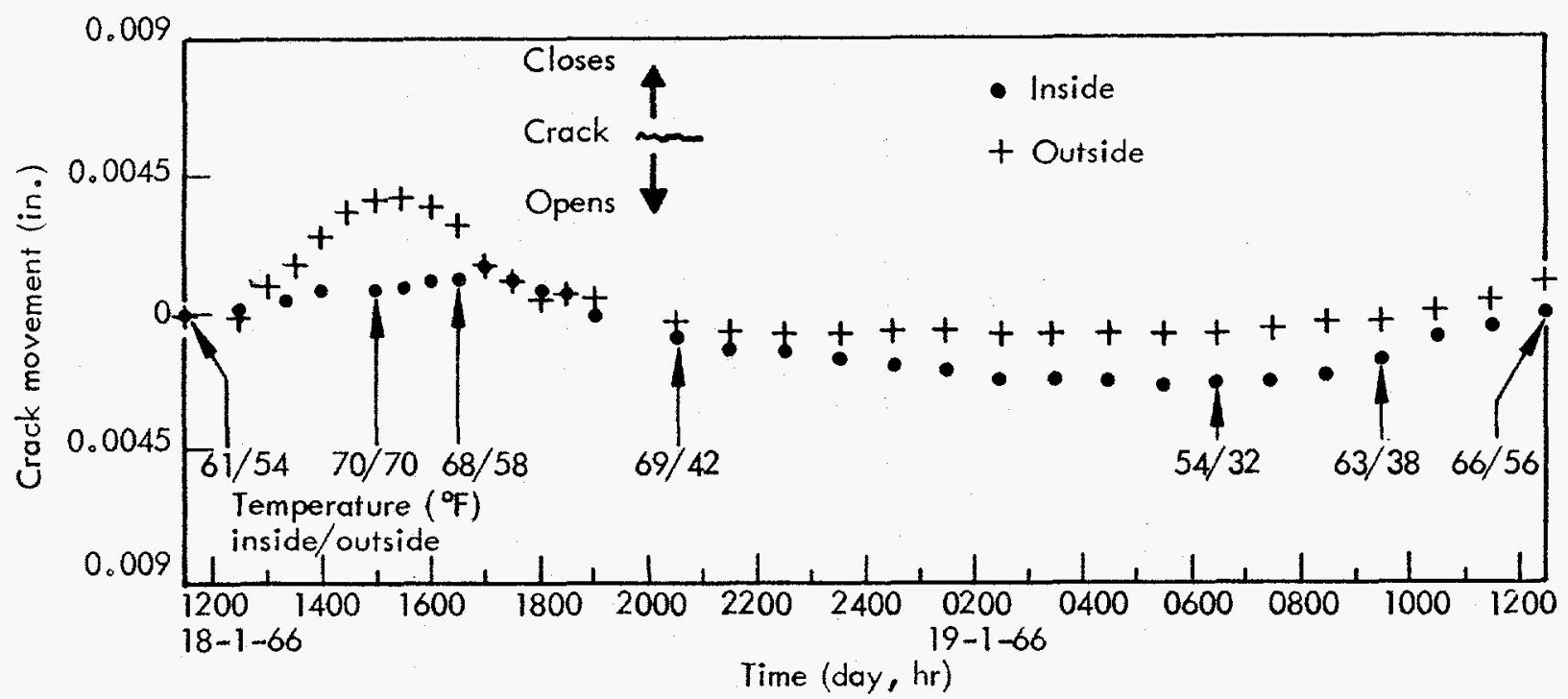

Fig. C-8. Movement of crack in Building 681 over a 24-hr period during Jan. 1966.

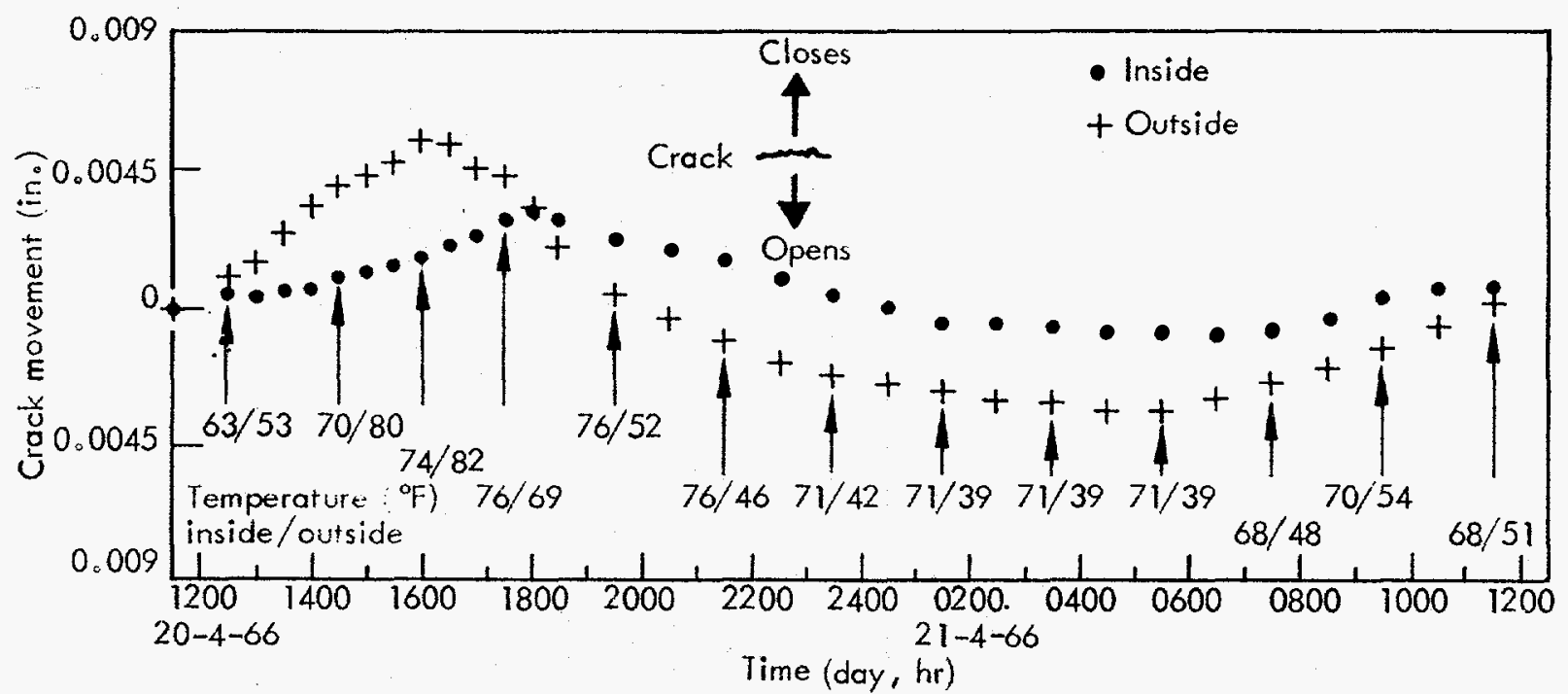

Fig. C-9. Movement of crack in Building 681 over a 24-hr period during Apr. 1966. 


\section{APPENDIX D}

BUILDING 425

Building 425, the new Fire Station at Mercury, was completed about 18 Jan. 1966. It was in such an unblemished, relatively perfect condition that the proposed plan was to make weekly inspections to determine, if possible, some indication of normal cracking rates for this type of building at Mercury.

Weekly inspections showed many new hairline shrinkage cracks developing and extending. It is believed, however, that most all of these would not be objectionable to the so-called fastidious home owner. Those few cracks considered to be of a more serious size and extent are listed under the $23 \mathrm{Mar}$. inspection. None are deemed sufficiently prominent to warrant photographic coverage. Inspections will continue.

Based on the record of the $23 \mathrm{Mar}$. inspection, the crack rate may be about 2 to 3 cracks/month with 2 to 3 doubtful cracks.

Table III. Inspection record of Building 425.

\begin{tabular}{|c|c|}
\hline Date of inspection & Condition observed \\
\hline 1 Dec. 1965 & Under construction \\
\hline 3 Dec. 1965 & Under construction \\
\hline 16 Dec. 1965 & Under construction \\
\hline 5 Jan. 1966 & Under construction \\
\hline 18 Jan. 1966 & Fresh paint on finished building; no cracks \\
\hline 15 Feb. 1966 & Cracks appearing in one vertical joint separation \\
\hline \multirow[t]{5}{*}{23 Mar. 1966} & $\begin{array}{l}\text { North side center, vertical hairline crack top to } \\
\text { bottom through foundation }\end{array}$ \\
\hline & $\begin{array}{l}\text { West side, south of door, vertical hairline crack top } \\
\text { to bottom through foundation }\end{array}$ \\
\hline & North side, west end, 6-block vertical hairline crack \\
\hline & $\begin{array}{l}\text { South side, west window, diagonal crack in right side } \\
\text { of sill }\end{array}$ \\
\hline & $\begin{array}{l}\text { South side, near east corner, vertical hairline crack } \\
\text { top to bottom with } 1 \text {-block step over at } 4 \text { th course } \\
\text { up }\end{array}$ \\
\hline
\end{tabular}


LRL Internal Distribution,

Information Department

M. May

G. Werth

G. Higgins

A. Holzer

M. Nordyke

H. Tewes

J. Knox

P. Bazilwich

W. Herlihy

D. Rabb

D. Montan

S. Warner

H. Zodtner

D. Power

J. Wall

LRL Nevada,

F. Perry

LRL Berkeley,

R. K. Wakerling

External Distribution,

Nuclear Cratering Group, Livermore, Calif.

W. Slazak

Nevada Operations Office, Las Vegas, Nevada,

J. Reeves

E. D. Alcock, U. S. Coast and Geodetic Survey

K. King, U. S. Coast and Geodetic Survey

Otto H. Roehlk, Operational Safety Division

Division of Peaceful Nuclear Explosives, Washington, D. C., J. Kelly 